\title{
Mandatory Sentencing Laws: Undermining the Effectiveness of Determinate Sentencing Reform
}

\author{
Gary T. Lowenthal $\uparrow$
}

Recent years have seen significant changes in sentencing law: determinate sentencing schemes and mandatory enhanced sentences have largely displaced discretionary sentencing regimes operating within broad sentencing constraints. Commentators have variously lamented and applauded the advent of both determinate sentencing and mandatory penalties, yet the interaction of these two innovations has been left largely unexamined. Professor Lowenthal provides an analysis of the perverse consequences that ensue when sentencing, guidelines are paired with mandatory sentencing: the very consistency and proportionality that these changes were supposed to engender can be undercut when the two sentencing approaches are combined. Mandatory sentencing emphasizes a single aggravating factor, contrary to determinate sentencing, which directs judges to a whole complex of factors. Mandatory sentencing also is applied unevenly, with those exercising their right to trial often receiving harsher penalties. Thus, a factor that should not be detrimental under determinate sentencing, such as exercising one's constitutional right to trial, is detrimental under mandatory sentencing. In sum, the goals of determinate sentencing-consistent punishment for like crimes and proportional punishment for different crimes-are greatly undermined by mandatory sentencing. Professor Lowenthal concludes by arguing for legislative changes to ameliorate the harsh and undesired effects of mandatory sentencing measures.

Two developments in the last twenty years have transformed felony sentencing in the United States. First, most jurisdictions have adopted determinate sentencing schemes that narrow the range of sanctions available to trial courts and reduce or eliminate the broad discretion previously exercised by corrections administrators and parole boards. ${ }^{1}$ At the

$\dagger$ Professor of Law, Arizona State University. A.B. 1966, Harvard University; J.D. 1969, University of Chicago. I wish to thank Jane Aiken, David Kaye, Ilene Nagel, Stephen Schulhofer, and Jin Weinstein, whose wise suggestions inıproved earlier drafts of this paper. Jennie Gorrell, Randall Hodgkinson, and Janissa Strabuk provided valuable researcli assistance.

1. Under indetermiuate sentencing systenss that previously existed, legislatures established broad parameters of permissible punishment for each offense category. Penalties ranged from no 
same time, legislatures have enacted mandatory sentencing laws that require significantly enhanced punishment in a large number of felony prosecutions, particularly those involving violent crimes and drug trafficking. ${ }^{2}$ While the success of the determinate sentencing reforms has been debated extensively, ${ }^{3}$ the joint effect of determinate sentencing and

incarceration at all to life imprisonment, even for relatively minor offenses. See In re Lynch, 503 P.2d 921, 922 (Cal. 1972) (statute authorizing imdeterminate sentence of up to life imprisonment for indecent exposure held unconstitutional). Judges in most of these systems set the maximum terms of imdividual sentences, and parole boards set actual periods of confinement within judicially determined maximums. See Mistretta v. United States, 488 U.S. 361, 36465 (1989) (describing the allocation of sentencing discretion under the federal system of indeterminate sentencing). On the relationship between the respective roles of judge and parole board in imdeterminate sentencing, see Alan M. Dershowitz, Indeterminate Confinement: Letting the Therapy Fit the Harm, 123 U. PA. L. REV. 297, 298-301 (1974).

For a discussion of the historical foundations of indeterminate sentencing, which became the predominant approach to punishment in American courts in the latter decades of the 19th century, see generally Howard B. Gill, A New Prison Discipline: Implementing the Declaration of Principles of 1870, Fed. Probation, June 1970, at 29. By 1922, only four states were without some form of parole or indeterminate sentencing system. Edward Lindsey, Historical Sketch of the Indeterminate Sentence and Parole System, 16 J. CRim. L. CRiminology \& Police SCI. 9, 69 (1925).

Parole board participation in sentencing has diminished in many jurisdictions in recent years. For example, the Minnesota Legislature limited the authority of the Minnesota Corrections Board. See MinN. STAT. ANN. $\$ 244.09$ (West 1991). Congress abolished the United States Parole Commission and restricted the availability of good-time credit for federal prisoners as part of the Sentencing Reform Act of 1984. Pub. L. No. 98-473, § 235(b), 98 Stat. 1837, 2031 (codified at 18 U.S.C. $\$ 3624(b)$ (1988)). Parole boards in most states nevertheless retain the authority to grant an early release from a prison sentence imposed in court. See, e.g., FLA. STAT. ANN. $\$ 947.13$ (West 1985 \& Supp. 1992); MASS. Gen. LAwS. ANN. ch. 127, § 128 (West 1991).

2. For a discussion of these statutes, see infra Part I.

3. See Dale G. Parent, Structuring Criminal Sentences: The Evolution of Minnesota's Sentencing Guidelines (Daniel J. Freed ed., 1988) (evaluating difficulties encountered in establishing a sentencing commission and promulgating guidelines); ANDREW vON Hirsch eT al., The SENTENCING Commission aNd ITS Guidelines (1987) (coinparing thc guidelines experience in several states); Albert W. Alschuler, The Failure of Sentencing Guidelines: A Plea for Less Aggregation, 58 U. CHI. L. REv. 901, 908-15 (1991) (discussing the failure of guidelines systems to take into account individual differences among offenders); John C. Coffee, Jr. \& Michael Tonry, Hard Choices: Critical Trade-offs in the Implementation of Sentencing Reform Through Guidelines, in REFoRM AND PUNISHMENT: EsSAYS IN CRIMINAL SENTENCING 155 (Michael Tonry \& Franklin E. Zimring eds., 1983) (analyzing difficulties in accomplishing goals of determinatc sentencing reform); Richard S. Frase, Sentencing Reform in Minnesota, Ten Years After: Reflections on Dale G. Parent's Structuring Criminal Sentences: The Evolution of Minnesota's Sentencing Guidelines, 75 MiNN. L. REV. 727 (1991) (discussing effects of political pressures on the state sentencing commission); Daniel J. Freed, Federal Sentencing in the Wake of Guidelines: Unacceptable Limits on the Discretion of Sentencers, 101 YALE L.J. 1681, 1690, 1730-40 (1992) (arguing that the federal guidelines are too rigid, complex, and severe and that appellate courts have been narrow-minded in applying the guidelines); Gerald $W$. Heaney, The Reality of Guidelines Sentencing: No End to Disparity, 28 AM. CRIM. L. REv. 161 (1991) (empirical evaluation of the federal sentencing guidelines); Stephen J. Scluulhofer, Assessing the Federal Sentencing Process: The Problem Is Uniformity, Not Disparity, 29 AM. CRIM. L. REv. 833, 851-70 (1992) (arguing that the greatest failure of federal sentencing reform is excessive uniformity, not undue disparity); Stephen J. Schulhofer \& Ilene H. Nagel, Negotiated Pleas Under the Federal Sentencing Guidelines: The First Fifteen Months, 27 AM. CRIM. L. REV. 231 (1989) (plea bargaining evasions undermine the goals of guideline seutencing); Andrew von Hirsch \& Julia M. Mueller, California's Determinate Sentencing Law: An Analysis of Its Structure, 10 NEw ENG. J. ON CRIM. \& CrV. CONFINEMENT 253 (1984) (evaluating problems existing under California sentencing reforms); Franklin E. Zimring, Sentencing 
mandatory minimunı punishments has not been subjected to careful scrutiny.

Determinate sentencing's principal goal has been the elimination of unwarranted disparity, with legislatures seeking proportional punishment for different offenses and consistent punishment for similar crimes. ${ }^{4}$ Accordingly, most jurisdictions have abandoned rehabilitation, once the central purpose of the indeterminate sentence, as a principal end of punishment. Current sentencing pohcy instead reflects a preference for retributive justice, with punishment commensurate with the seriousness of each type of offense. ${ }^{5}$ Some state legislatures, following the lead of California's 1976 Unifornn Determinate Sentencing Law, ${ }^{6}$ have prescribed a presuniptive sentence for each statutory offense, with a narrow range of permissible deviations from the legislative presuinption. ${ }^{7}$ Other states and Congress have structured sentencing discretion by requiring judges to follow guidelines promulgated by a sentencing commission. ${ }^{8}$

Reform in the States: Lessons From the 1970s, in REForm AND Punishment: Essays In CRIMINAL SENTENCING, supra, at 101 (analyzing problems of determinate sentencing laws).

Much of the debate over the wisdom of determinate sentencing reform has centered on the federal sentencing guidelines. Crities have charged that the federal guidelines are unduly coinplex, rigid, and likely to result in unwarranted disparities. Others have defended the guidelines. See infra note 117 .

4. Many critics of indeterminate sentencing in the 1970 s and early 1980 s argued that disparate treatment of similar cases required a inove toward determinate punishment. See infra note 223. The modern goals of uniformity and proportionality in sentencing sometimes conflict with one another. See William W. Wilkins, Jr., The Federal Sentencing Guidelines: Striking an Appropriate Balance, 25 U.C. DAvis L. REV. 571, 573-76 (1992).

5. For a discussion of the ascendance and decline of rehabilitation as a principal goal of sentencing, see Francis A. Allen, The Decline of the Rehabilitative Ideal: Penal Policy and Social Purpose (1981); Norval Morris, The Future of IMPrisonment 24-43 (1974); Ilene H. Nagel, Foreword-Structuring Sentencing Discretion: The New Federal Sentencing Guidelines, 80 J. Crim. L. \& Criminology 883, 893-99 (1990). One commentator has criticized the assumption unade by several courts, sentencing commissions, and commentators that the move away froin indeterminate sentencing requires a harm-based retributive sentencing philosophy. See Alschuler, supra note 3, at 908-15.

6. CaL. Penal Code $\$ \S 1170,3000,3040$ (West Supp. 1992).

7. See, e.g., Alaska Stat. $\$ \S 12.55 .125-.145$, .155-.165 (1991); ArIz. Rev. Stat. ANN. $\S \S 13-701,-702$ (1991); Colo. REV. STAT. § 18-1-105 (Supp. 1991); Ill. ANN. STAT. ch. 38, paras. 1005-5-1 to -3 (Sunith-Hurd Supp. 1992); IND. CodE ANN. $\$ \S 35-50-2-1$ to -10 (West 1986 \& Supp. 1991); N.C. GEN. STAT. §§ 14-1.1, 15A-1340.4 (1986 \& Supp. 1991).

8. In 1978, Miunesota was the first state to establisl a sentencing cominssion to prounulgate guidelines. See MINN. STAT. ANN. § 244 app. (West 1992); Act of Apr. 5, 1978, ch. 723, § 9, 1978 Minn. Laws 761, 765-67 (codified as amended at MiNN. STAT. ANN. $\$ 244.09$ (West 1992)) (enabling legislation). The Minnesota system served as a model for other states. See, e.g., WASH. Rev. Code ANN. § 9.94A.310 (West Supp. 1992); 204 PA. CODE $§ \S 303.1-.9$ (1991). By early 1992 at least 13 states had adopted guidelines systems or had established sentencing coinumissions to develop sentencing standards. See Kay A. Knapp \& Denis J. Hauptly, State and Federal Sentencing Guidelines: Apples and Oranges, 25 U.C. DAvis L. REv. 679, 681 (1992) (discussing the inplementation of guidelines sentencing systems in Florida, Kansas, Louisiana, Michigan, Minnesota, North Carolina, Ohio, Oregon, Pennsylvania, South Carolina, Tennessee, Texas, and Washington). For a discussion of the state court experience under guidelines sentencing, see Frase, supra note 3; John M. Junker, Guidelines Sentencing: The Washington Experience, 25 U.C. DAvis L. REV. 715 (1992); Laird C. Kirkpatrick, Mandatory Felony Sentencing Guidelines: The Oregon 
Under each of these approaches, trial courts determine sentences in individual cases by weighing the aggravating and mitigating circumstances of the offense.

While determinate sentencing statutes seek proportionality by balancing multiple factors, mandatory sentencing statutes generally provide that when a specified circumstance exists in comrection with the comunission of a crime (1) the court must sentence the defendant to prison and (2) the duration of the defendant's incarceration will be substantially longer than it would have been in the absence of the circumstance. Unlike the comprehensive determinate sentencing reforms, the singlefactor sentence enhancement laws have been enacted piecemeal, usually during election years. ${ }^{9}$ Increasingly, legislatures have enacted mandatory sentencing laws with severe penalty provisions to send a deterrent message to those contemplating committing serious crimes, with the result that mandatory pumishment now pervades the criminal justice system at both the state and federal levels. By 1990, forty-six states had enacted mandatory sentence enhancement laws, ${ }^{10}$ and most

Model, 25 U.C. Davis L. Rev. 695 (1992). Congress authorized the most ambitious and comprehensive guidehine sentencing system in the Federal Sentencing Reform Act of 1984, which created the United States Sentcncing Commission and authorized it to promulgate an elaborate set of guidelines for district courts to follow. 28 U.S.C. $\$ 994$ (1988). Similar reform has occurred in England. See Andrew Ashworth, The New English Sentencing System, 25 U.C. DAvis L. Rev. 755 (1992) (discussing the sentencing reforms included in the English Criminal Justice Act of 1991). Finland and Sweden also have adopted determinate sentencing reforms. Id. at 755-56.

9. Congress enacted the primcipal federal mandatory sentence laws during election years. In 1968, when Richard Nixon made street crime a major issue in the presidential campaign, Congress enacted a law that required a consecutive sentence for the use of a firearm in the commission of an offense. 18 U.S.C. $\$ 924$ (c) (1988 \& Supp III 1991). In 1984, Congress amended $\S 924$ (c) to increase the mandatory minimum sentence. Act of Oct. 12, 1984, Pub. L. No. 98-473, §§ 223(a), 1005(a), 98 Stat. 1837, 2028, 2138. Congress toughened the gun law again in 1986, see Fircarms Owners' Protection Act, Pub. L. No. 99-308, § 104(a)(2), 100 Stat. 449, $456-57$ (1986), in 1988, see Undetectable Firearms Act of 1988, Pub. L. No. 100-649, § 2, 102 Stat. 3816, 3816-17, and in 1990, see Crime Control Act of 1990 , Pub. L. No. 101-647, §1702(b)(3), 104 Stat. 4789, 4845, each time shortly before congressional elections. Similarly, Congress enacted each of the federal punishment provisions related to drug trafficking in election years. One mouth beforc the 1984 congressional elections, Congress enacted the Controlled Substances Penalties Amendment Act, a chapter of the Comprehensive Crime Control Act of 1984, Pub. L. No. 98-473, \& 501, 98 Stat. 1837, 2068. The Act provided mandatory minimum sentences for several drug offenses. Congress continued its election year "war on drugs" with the Anti-Drug Abuse Act of 1986, Pub. L. No. 99-570, 100 Stat. 3207 , setting mandatory minimum sentences according to the weight of mixtures or substances containing controlled substances. See 21 U.S.C. $\$ 841$ (b)(1) (1988 \& Supp. III 1991). In the AntiDrug Abuse Act of 1988, Congress toughened the mandatory minimum drug distribution sentence provisions yet again; it established a potential mandatory minimum sentencc of five years for the simple possession of a small amount of "crack" cocaine and increased the required punishment for other offenses. See Pub. L. No. 100-690, §6371, 102 Stat. 4181, 4370 (codified at 21 U.S.C. § 844(a) (Supp. III 1991)). In 1990, when the Judicial Conference recommended the repeal of existing mandatory minimum sentences, Congress responded by enacting legislation providing for additional mandatory minimums. See Donald P. Lay, Rethinking the Guidelines: A Call for Cooperation, 101 YALE L.J. 1755, 1756 (1992) (describing congressional action as "politically expedient").

10. Marc Mauer, Americans Behind Bars, CRIM. JusT., Winter 1992, at 16. 
states had a wide variety of these provisions. ${ }^{11}$ Over 100 separate federal provisions currently require mandatory minimum sentences, ${ }^{12}$ accounting for over 60,000 federal sentences between 1984 and $1990 .{ }^{13}$

I argue in this Article that the interaction between determinate sentencing and mandatory pumishment results in precisely the same type of unwarranted sentencing disparity that characterized indeterminate sentencing laws. If the trend toward superimposing severe mandatory sentencing on guideline systems is not reversed, it may destroy consistency and proportionality in punishment and thwart the very purpose of sentencing reform. I also argue that mandatory sentencing laws have untoward effects on the processing of criminal cases. The threat of harsh inandatory punishment often deters persons accused of felony offenses from asserting their constitutional rights and defending themselves in court.

Part I of this Article discusses the principal purposes of mandatory punishment, provides a brief history of mandatory sentencing in the Umited States, and identifies the primcipal forms of mandatory punishinent statutes enacted in recent years. Mandatory sentencing laws serve the utilitarian ends of crime deterrence and the incapacitation of serious offenders. Legislatures have targeted particular classes of offenders and offenses for certain and severe punishment and have employed a wide variety of inechanisms to achieve these goals. Part I describes common characteristics of these devices, categorizes the cases in which mandatory punishment is used, and discusses the effects of mandatory punishment on correctional resources.

In Part II, this Article explores the effect of mandatory sentencing legislation on criminal procedure. Severe sentencing laws force jurisdictions to choose between two approaches for establishimg the facts necessary to trigger mandatory sentence provisions. The first approach is charge-based sentencing; it requires courts to impose mandatory punishment ouly when the prosecution has alleged the facts triggering the sentencing provisions as part of the charging instrument and has proven thein at trial, or the defendant has adimitted them. ${ }^{14}$ This gives prosecutors powerful bargaining leverage to force defendants to plead guilty on terms dictated by the government and makes it risky for defendants to exercise their constitutional right to trial. The second approach is conduct-based sentencing; it directs the court to determine the facts that trigger the mandatory minimum sentence at the time of sentencing, even

11. See infra Section I.B.

12. U.S. Sentencing Comm'n, Mandatory Minimum Penalties in the federal CRIMINAL JUSTICE SYSTEM 10 (1991). The Sentencing Commission's report also described over 30 mandatory sentencing bills before Congress as of August 1991. Id. at app. B.

13. Id. at 13 .

14. See infra notes $57-63$ and accompanying text. 
if they have not been alleged in the charging instrument and proven at trial. ${ }^{15}$ This approach leads to informal and potentially unreliable factfinding and threatens the ability of the exclusionary rule to enforce constitutional rights.

Part III discusses the incompatibility of the recent proliferation of mandatory pumishment legislation with the goals of the contemporaneous determinate sentencing inovement. I argue that mandatory sentencing laws inherently result in unwarranted disparities because they require substantially increased punishment based on the presence of a simgle aggravating circunistance, without regard to the total mix of aggravating and mitigatimg circunistances present in individual cases. ${ }^{16}$ Mandatory punishment provisions also tend to be enforced unevenly; the defendants punished inost severely are often those who exercised their coustitutional rights. ${ }^{17}$ Mandatory sentencing legislation thus severely undermines the determinate sentencing objectives of consistent punishment for similar crimes and proportional punishment for different offenses.

Part IV examines constitutional issues related to the severity and rigidity of sentencing laws, as well as the Supreme Court decision im Harmelin v. Michigan. ${ }^{18}$ In Harmelin, the defendant was convicted of simple possession of cocaine and sentenced to life miprisonment without parole. ${ }^{19}$ Although the Court split five to four in favor of upholding the defendant's sentence, a clear message einerged from the various opimions: rehef froin the larsh effects of mandatory punishment inust come from legislatures, not courts. ${ }^{20}$

In the Conclusion I argue that legislatures inust act on Harmelin's inessage. Although the repeal of nost inandatory sentencing laws is unlikely in today's political chmate, I suggest alternative measures that may be more palatable. I suggest that the legislative branch can reduce the rigidity of sentence enhancement laws by authorizing trial courts to depart froin them when substantial and compelling mitigating circumstances exist. Additionally, legislatures can decrease the severity of inost mandatory punishment laws. Only then will guideline sentencing serve the goals of consistency and proportionality it seeks to achieve.

15. See infra notes $64-68$ and accompanying text.

16. See infra text accompanying notes 223-38.

17. See infra text accompanying notes 239-47.

18. 111 S. Ct. 2680 (1991).

19. Although the defendant had 672 grams of cocaine in his possession, id. at 2684 (plurality opinion), an amount far larger than one could plausibly argue was for personal consumption, the prosecutor chose not to charge him with possession with intent to distribute the drug, id. at 2718 (White, J., dissenting).

20. Id. at 2703 (Kennedy, J., concurring in part and in the judgment) ("[T] he fixing of prison terms for specific crimes involves a substantive penological judgment that, as a general matter, is 'properly withm the province of legislatures, not courts.' ") (quoting Rummel v. Estelle, 445 U.S. 263, 275-76 (1980)). 


\section{Common Themes of Mandatory Punishment Legislation}

The principal rationales of inandatory sentencing laws are utilitarian. $^{21}$ Long prison sentences for recidivists, drug traffickers, and those who commit violent crimes isolate thein froin the general community and thereby prevent them from committing further crimes outside prison walls. Mandatory sentencing provisions are also designed to deter, sending the message to potential offenders that harsh consequences follow from their criminal conduct. Legislatures have made imprisonment both more certain and more severe in order to respond to constituent concerns about crime and safety, and to fulfill the broad purpose of general criminal deterrence. ${ }^{22}$ Prohibiting courts front suspending seutences or placing defendants on probation niakes imprisonment more certain. ${ }^{23}$ Several statutory devices increase the severity of sentences.

Some statutes, for example, require the convicted offender to serve a mandatory minimum prison tern that otherwise would not be applicable to commission of the offense. ${ }^{24}$ Other provisions increase both the statutory minimum and nraximum sentences that otherwise may be iniposed. ${ }^{25}$ Some statutes require consecutive sentences for the underlying offense and the enhancing (triggering) circumstance. ${ }^{26}$ Others

21. See U.S. SENTENCING COMM'N, supra note 12, at 13-15 (citing retribution, deterrence, incapacitation, elimination of disparity, inducement of cooperation, and inducement of pleas as reasons for inandatory minimums). Deterrence, inducement of cooperation, and inducement of pleas can cach be seen as utilitarian in that each depends on changes in the potential offender's and accused's utility function. Increased certainty and severity of punishment are assumed to cause the potential offender or accused to weigh the cost of nonconforming behavior more heavily before acting.

22. Id. at 14.

23. See, e.g., CAL. PENAL CODE $\S 462$ (West 1988) (requiring a prison sentence for first-time residential burglars except in unusual cases where the interests of justice are best served if the person is granted probation); ILL. ANN. STAT. ch. 38, para. 1005-5-3(c)(2) (Smith-Hurd Supp. 1992) (enumerating classes of offenders who are not ehgible for probation); MINN. STAT. ANN. § 609.11(5) (West 1987) (no probation or suspended sentence if defendant or an accomplice used or displayed a firearm in the coinumission of the offense).

24. See, e.g., 21 U.S.C. \$ 841(b)(1)(A) (1988 \& Supp. III 1991) (unandatory mininum 10-year prison term for possession, nuanufacture, or distribution of at least one kilogram of heroin, five kilograms of cocaine, or specified quantities of other controlled substances); FLA. STAT. ANN. $\S 775.087(2)(a)(2)$ (West 1992) (mandatory minimum three-year sentence for battery committed on a law enforccment officer while possessing a firearm); N.J. STAT. ANN. § 2C:43-6(c) (West Supp. 1992) (Inandatory minimum sentence of at least three years in prison or one-third to one-half of total sentence, whichever is greater, for use or possession of a firearm in the commission of specified felonies); 42 PA. CoNs. STAT. ANN. § 9712(a) (1982) (mandatory mininuun five-year sentence for visibly possessing a firearm when committing one of several specified felonies).

25. See, e.g., FLA. STAT. ANN. \$ 775.087(1) (West 1992) (higher classification for offense, increasing both minimum and maximum sentences, for possession or use of a weapon in commission of the offense); N.Y. PENAL LAw $\S \S 70.04-06$ (McKinney 1987) (both minimun and nuaximum sentence increased for repeat offenders); WASH. REV. CODE ANN. § 9.94A.310(3) (West Supp. 1992) (both presumptive sentence and sentencing range are iucreased if defendant or an acconuplice were armed with a deadly weapon during the coinmission of the offense).

26. See, e.g., 18 U.S.C. $\$ 924$ (c) (1988 \& Supp. III 1991) (five-year nuandatory sentence for use 
increase severity by restricting administrative discretion, either by delaying or eliminating parole eligibility or by prohibiting sentence credit for good behavior in prison. ${ }^{27}$ Most statutes coinbine inany of these features and thus require judges to sentence offenders to prison and assure that the incarceration is lengthy. This achieves the twin goals of general deterrence and incapacitation, without regard to judicious punishment in individual cases.

The concept of mandatory punishment is not new. Colonial legislatures establislied fixed penalties for most criminal offenses and allowed courts little or no flexibility when imposing punishment in individual cases. ${ }^{28}$ By the early years of the nineteenth century, lowever, inandatory fixed sentences had become increasingly rare. Most states, reacting to the rigidity of colonial sentencing scliemes, revised their criminal laws to give trial courts greater sentencing discretion. ${ }^{29}$ Mandatory punishment resurfaced a century later, when the New York Legislature enacted a statute in 1926 requiring a life sentence if a person convicted of

of a firearm in the commission of an offense, to be served consecutive to the sentence for the underlying offense); CAL. PENAL CODE $\$ 667$ (West Supp. 1992) (mandatory five-year consecutive sentence in addition to the sentence for the underlying felony if defendant has a prior serious felony conviction and is convicted of a serious felony or any offense in another jurisdiction that includes all the elements of a serious felony); UTAH CODE ANN. § 76-3-203(4) (1990) (mandatory 5- to 10-year addition to sentence for use of a frearm in the commission of an offense).

27. See, e.g., ALA. CODE § 13A-12-231(2)(d) (Supp. 1991) (mandatory life imprisonment without possibility of parole for certain drug offenders); ARIZ. REV. STAT. ANN. $\S 13-604.02$ (1989) (a serious felony conviction while on probation or parole precludes eligibility for parolc, work furlough, or release from confinement until the entire sentence has been served); CAL. PENAL CODE $\S 667.75$ (West 1988) (minimum 17-year incarceration required before parole eligibility for certain drug offenses); Mich. COMP. LAws ANN. $\$ 791.234$ (4) (West Supp. 1992) (limited parole eligibility for a person committing a "major" controlled substance offense); MINN. STAT. ANN. $\$ 609,11(6)$ (West 1987) (no parole eligibility for persons convicted of specified offenses); N.D. CENT. CODE $\S 12.1-32-02.1$ (1985) (no parole eligibility if the person convicted has inflicted bodily injury or has used or threatened to use a dangerous weapon in the commission of the offense).

28. Legislatively determined punishments in colonial courts included fines, whipping, forced labor, the pillory, and death. See Alan M. Dershowitz, Background Paper to TweNTIETH Century Fund Task Force on Criminal. Sentencing, Fair and Certain Punishment 67, 83-84 (1976) [hereinafter FAIR AND CERTAIN PUNISHMENT] (describing colonial sentencing systems). The French Penal Code of 1791 is another example of legislatively fixed sanctions for each offense category with no flexibility allowed for sentencing individual offenders. Paul W. Tappan, Sentencing Under the Model Penal Code, 23 LAw \& ConTEMP. ProBs. 528, 529 (1958).

29. Many of these revisions restricted capital punishment, abolished many forms of corporal punishment, and made imprisonment the principal nethod of punishing offenders. Dershowitz, supra note 28 , at $87-88$. Early 19 th-century legislatures typically set maximum permissible punishments for each offense category, which depended on the generic seriousness of the offense, but left the decision concerning the actual duration of imprisonment to trial courts to determine on a case-by-case basis. For example, an early New York statute provided that the maximum prison sentence for the offense of assault was 14 years. 1801 N.Y. Laws 58. The trial court in an individual case could impose a specific sentence of any duration not exceeding the statutory maximum. Sinilarly, a Massachusetts law provided that the maximum punishment for maiming another person was confinement for up to 10 years, but the actual term of incarceration was to be determined by the court, based on the court's assessment of the "nature and aggravation of the offence." Act of Mar. 15,1805 , ch. 123, $\S 4,1804$ Mass. Acts 179, 180. 
a felony offense had two prior felony convictions. ${ }^{30}$ In the years preceding World War II, most states enacted similar measures aimed at habitual offenders, typically requiring courts to impose life sentences for a third or fourth felony conviction. ${ }^{31}$ However, apart from these early recidivist laws and a few provisions enacted in the 1950s, most of the current mandatory enhancement laws did not appear until the 1970 s. $^{32}$

\section{A. Operation}

Modern mandatory sentence enhancement legislation differs from the fixed sentences imposed in colomal times. Most of the current laws do not set the penalties for criminal offenses themselves, but instead require substantially increased punishment when a specified aggravating circumstance exists in connection with the commission of a crime. For example, 21 U.S.C. $\$ 841$ (a) prohibits trafficking in certain drugs, imcluding cocaine. ${ }^{33}$ The basic penalty for a first violation of this statute is imprisonment with no minimum term and a maximum term of twenty years. The offender is ehgible for a suspended sentence or a grant of probation as an alternative to incarceration. ${ }^{34}$ However, the penalties increase dramatically as the amount of drugs involved mcreases. If the offender distributes 500 grains or more of a mixture or substance contaming a detectable amount of the drug, the statute enhances the pumshment to a term of imprisonment that may not be less than five years, nor more than forty. Additionally, the defendant is no longer eligible for probation or a suspended sentence. ${ }^{35}$ When the weight is five kilograins or more, the mandatory minimum sentence becomes ten years in prison and the maximum term is life innprisonment, with no probation ehigibility. ${ }^{36}$

The sentence enhancement provisions of the statute accomphish two things. First, increases in the minimum sentence-from no imprisonment to five years and then to ten years-assure that convicted offenders serve substantial prison terms. Second, elimination of probation and sus-

30. See Paul W. Tappan, Habitual Offender Laws in the United States, Fed. Probation, Mar. 1949, at 28, 28 (describing the New York law and similar legislation in other states).

31. By 1949, 43 of the 48 states had enacted habitual offender statutes, but not all of them required courts to impose enhanced sentences on repeat offenders. Id.

32. In 1953, California enacted a statute providing that if a person was armed with a firearm in the commission of a felony, the court was to impose a consecutive 5- to 10-year sentence in addition to the sentence for the underlying offense. See CAL. Penal Code $\S 12022$ (a) (West Supp. 1992). This provision has been amended to comport with California's determinate sentencing laws, and now requires a one-year consecutive sentence. Id. Congress also enacted a mandatory punishment statute which established mandatory minimum sentences for certain categories of drug importation and distribution offenses in the Narcotic Control Act of 1956, Pub. L. No. 84-728, 70 Stat. 567.

33. The statute prohibits manufacturing and distributing drugs, in addition to possessing them with the intent to distribute. 21 U.S.C. $\$ 841$ (a) (1988).

34. 21 U.S.C. $\$ 841$ (b)(1)(C) (1988).

35. Id. $\S 841(\mathrm{~b})(1)(\mathrm{B})(1988$ \& Supp. III 1991).

36. Id. $\S 841(\mathrm{~b})(1)(\mathrm{A})$. 
pended sentences as alternative punishments makes imprisonment mandatory.

\section{B. Types of Sentence Enhancement Provisions}

A wide variety of circumstances trigger enhanced penalties under the statutes. Most jurisdictions have adopted provisions requiring substantially longer prison sentences when a person possesses or uses a dangerous weapon during the commission of an offense. ${ }^{37}$ Enhanced sentences for repeat felony offenders are also common. ${ }^{38}$ Other common targets of enhancement legislation are persons who possess or distribute

37. See 18 U.S.C. $\$ 924(c)$ (Supp. III 1991) (mandatory minimum five-year addition to sentence for use of firearm in commission of violent or drug trafficking offense); ALA. CODE $§ 13 \mathrm{~A}$ 5-6(a)(4), (a)(5) (1982) (mandatory minimum sentence when a deadly weapon is used in the commission of an offense); ARIZ. REV. STAT. ANN. § 13-604(F)-(G) (1989) (substantially increased punishment for use or exhibition of a deadly weapon or dangerous instrument in the commission of a felony); CAL. Penal Code $\S \S 12022,12022.3, .5$ (West Supp. 1992) (inandatory consecutive sentence for possession or use of a firearm in the commission of an offense); COLO. REV. STAT. § 1611-309(1)(b) (Supp. 1991) (mandatory sentence for use of a deadly weapon in a crime against an elderly or handicapped person); FLA. STAT. ANN. $\$ 775.087(1)$ (West 1992) (possession or use of a weapon in the commission of an offense increases sentencing classification); 38 ILL. ANN. STAT. ch. 38, para. 33A-3 (Smith-Hurd Supp. 1992) (dangerous weapon used in the commission of a felony results in its reclassification with substantially enhanced punishment); ME. REV. STAT. ANN. tit. 17A, $\S 1252(5)$ (West 1983) (mandatory minimum sentence if a felony is committed with the use of a firearm against another person); MINN. STAT. ANN. §609.11(4)-(5) (West 1987) (mandatory iminimum sentence if defendant or an accomplice possesses, uses, or displays a dangerous weapon or firearm); N.J. STAT. ANN. § 2C:43-6(c) (West Supp. 1992) (mandatory minimum sentence for use or possession of a firearm in the commission of specified felonies); N.Y. PENAL LAw $\$ \S 265.08-09$ (McKinney 1989) (separate statutory offense to commit a serious felony while possessing a loaded firearm or displaying what appears to be a firearm); N.D. CENT. CODE § 12.1-32-02.1 (1985) (mandatory ininimum sentence for inflicting bodily injury or threatening use of a dangerous weapon in the commission of an offense); 42 PA. CoNs. STAT. ANN. § 9712(a) (1982) (mandatory five-year minimum sentence for possessing a firearm when committing certain offenses); UTAH CODE ANN. § 76-3-203 (1990) (inandatory consecutive sentence for use of a firearm in the commission of the offense); WASH. REV. CODE ANN. \$ 9.94A.310(3) (West Supp. 1992) (enhanced guideline sentence if the offender or an accomplice is armed with a deadly weapon in the commission of specified offenses).

38. See ALA. CODE § 13A-5-9 (1982) (sentence range increased for repeat offenders); ARIZ. REv. StAT. ANN. \&13-604(A)-(C) (1989) (substantially enhanced prison sentence with delayed parole eligibility for repetitive offenders); CAL. PENAL Code $\S \S 667,667.5(a), .6$ (West Supp. 1992) (added sentence if defendant has prior convictions); CoLo. REv. STAT. § 16-13-101 (1990) (habitual criminal sentence enhancement); ILL. ANN. STAT. ch. 38, paras. 1005-5-3(c)(8), -8-2 (Smith-Hurd Supp. 1992) (higher classification and enhanced punishment for various classes of repeat offender); IOWA CODE ANN. § 902.8 (West 1979) (mandatory three-year minimurn for repeat offender); MrCH. COMP. LAWS ANN. $\$ \S 769.10-.12$ (West Supp. 1992) (enhanced penalties for subsequent convictions); N.Y. PENAL LAW $\S \S 70.04-10$ (McKinney 1987) (both maximum and minimum sentences increased for repeat offenders); OHIO REv. Code ANN. § 2929.11(B) (Anderson Supp. 1991) (increased ininimum term and no eligibility for probation or suspended sentence if the offender has a prior conviction); OKLA. STAT. ANN. tit. 21, $\$ 51$ (West Supp. 1992) (increased sentences for repeat offenders); 42 PA. CONS. STAT. ANN. $§ 9714$ (1982 \& Supp. 1992) (mandatory minimum sentences for a second conviction for specified offenses); Tex. PENAL CODE ANN. $\S 12.42$ (West 1972 \& Supp. 1992) (enhanced punishments for repeat offenders); WYO. STAT. § 6-10-201 (1988) (habitual criminal statute). 
prohibited drugs exceeding a specified weight or amount, ${ }^{39}$ those who commit crimes against vulnerable victims such as children or elderly persons, ${ }^{40}$ and those who commit crimes while released from custody for other offenses. ${ }^{41}$

In addition to these common enhancement laws, legislatures have targeted specific categories of offenders for particularly harsh sentences, usually in response to a highly publicized or ennotionally charged offense or crime spree. ${ }^{42}$ A California law inandates a consecutive sentence if a sex offense is committed by a day-care provider; ${ }^{43}$ a Pennsylvania statute requires a five-year minimum sentence for a serious offense committed in or near a public transportation facility; ${ }^{44}$ a Texas statute requires increased punishment for a felony against a child victim committed during a ritual or ceremony; ${ }^{45}$ a Florida provision increases a sentence when an offender wears a mask during the commission of a felony; ${ }^{46}$ a federal statute mandates a twenty-year prison sentence for an offense committed aboard an aircraft outside the United States; ${ }^{47}$ and another federal provision requires an enhanced sentence for transporting a minor with knowledge that the minor will be sexually exploited..$^{48}$

39. See 21 U.S.C. § 841(b)(1)(A)-(B) (1988 \& Supp. III 1991) (mandatory minimum sentences for possession, manufacture, or distribution of a mixture or substance containing specified weights of heroin, cocaine, LSD, etc.); CAL. HeALTh \& SAFETY CODE $\$ 11370.4$ (West 1991) (enhanced consecutive sentences for drug offenses when the weight or volume of the drug is over statutory amounts); MrCH. CoMp. Laws ANN. §333.7403(2)(a)(i) (West Supp. 1991) (mandatory hife imprisonment for possession of 650 grams or more of cocaine).

40. See 18 U.S.C. § 2251A (1988) (mandatory 20-year sentence for knowingly buying or selling a child for use in child pornography); id. $\$ 2252$ (1988 \& Supp. III 1991) (mandatory fiveyear sentence for a second offense of shipping or receiving sexually explicit material involving children); ARIz. REV. STAT. ANN. §13-604.01 (1989) (mandatory prison enhancements for dangerous crimes against children); CAL. PENAL CODE § 667.9(a) (West 1988) (two-year sentence enhancement when the offender has a prior conviction and the victim is age 65 or older, blind, paraplegic, quadriplegic, or under age 14); CoLo. REv. STAT. § 16-11-309(1)(b) (Supp. 1991) (enhanced sentence for use of a deadly weapon in a crime against an elderly or handicapped person); FLA. STAT. ANN. § 775.087(2) (West 1992) (mandatory three-year minimum sentence for battery committed against a law enforcement officer); TEX. PENAL Code ANN. $\$ 12.47$ (West Supp. 1992) (enhanced punishment for the commission of a crime against a child in a ritual or ceremony).

41. See ARIz. REv. STAT. ANN. \$13-604.02 (1989) (substantially enhanced mandatory prison sentences for felonies committed while the offender is released from custody for another offense); CAL. PENAL CODE $\S 12022.1$ (b) (West Supp. 1992) (two-year sentence enhancement for committing a felony offense while free on bail for a separate offense).

42. Some mandatory sentence provisions have unique triggers. For example, a federal statute requires a 10-year prison term for obstructing a person who is trying to escape from a wrecked or stranded vessel. 18 U.S.C. $\S 1658$ (b) (1988). Another requires a one-year sentence for bribing a meat inspector. 21 U.S.C. $\S 622$ (1988).

43. Cal. Penal Code $\S 674$ (West 1988).

44. 42 Pa. Cons. Stat. ANN. $\S 9713$ (1982).

45. Tex. Penal Code ANn. $\S 12.47$ (West Supp. 1992).

46. FLA. Stat. ANN. $\S 775.0845$ (West Supp. 1992).

47. 49 U.S.C. $\S 1472(\mathrm{n})(1)(\mathrm{A})(1988)$.

48. 18 U.S.C. $\$ 2251 \mathrm{~A}$ (1988). 


\section{Effects on Prison Populations}

Not surprisingly, prison populations have imcreased dramatically since the proliferation of mandatory punishment laws. ${ }^{49}$ Pinpointing the precise causes of the ever-expanding prison population is difficult because many factors-such as improved law enforcement, changes in prosecutorial or investigative priorities, and greater severity in sentencing laws in general-may have contributed to the increase in the nuniber of persons sentenced to prison and to the length of their sentences. Nevertheless, mandatory punishment provisions must be counted as a major contributor for several reasons..$^{50}$ First, elimination of trial court discretion to suspend prison sentences and/or place defendants on probation naturally increases the percentage of arrested offenders who are sentenced to prison. ${ }^{51}$ Second, the average sentence imposed in court for persons imprisoned with mandatory enhancements is inuch longer than the average sentence for offenders sent to prison without them. ${ }^{52}$ Third, even when courtrooin sentences are equal, the actual period of confine-

49. The California prison system is typical. In 1980, it housed 22,000 prisoners at 12 facilities. Ten years later it held 97,000 inmates in 20 facilities. Andrew H. Malcolm, More Cells for More Prisoners, but to What End?, N.Y. TIMES, Jan. 18, 1991, at B16. The federal prison population is expected to increase by $119 \%$ from 1987 to 1997 , as a result of the Federal Sentencing Guidelines and harsh mandatory punishments for drug offenses. U.S. SENTENCING CoMm'N,

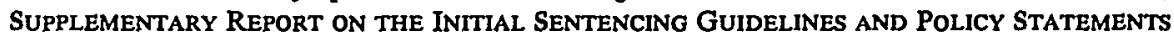
71 (1987). While the overall crime rate in the United States dropped by 3.5\% between 1980 and 1991, the number of persons incarcerated in American prisons doubled in that period. Mauer, supra note 10, at 16. The United States has by far the world's highest known rate of incarceration. Id. at 14. The total cost of incarcerating the more than one million Americans in prisons and jails reached $\$ 16$ billion a year in 1991. Id.

50. Concerned with the impact of rigid and severe determinate sentencing provisions on prison populations, guidelines-sentencing commissions in some states have taken the availability of correctional resources into account when establishing guidelines-sentencing ranges. See Kirkpatrick, supra note 8, at 695 (Oregon guidelines linked to prison resources); Knapp \& Hauptley, supra note 8, at 688 (analyzing how resource availability affects state versus federal practice).

51. In 1980, 196 offenders were sentenced to prison for every 1,000 felony arrests. Mauer, supra note 10, at 16. Seven years later, that figure had increased by $54 \%$ to 301 per 1,000 arrests. Id. Trial judges have frequently complained that mandatory punishment laws have required them to send many persons to prison who do not belong there. See Aaron Epstein, Judges Protesting Mandatory Drug Sentences, Seattle Times/Post Intelligencer, May 19, 1991, at A7 (quoting numerous judges complaining about mandatory prison sentences). United States District Judge Lawrence Irving, appointed by President Reagan in 1982, felt so strongly about the rigidity of mandatory sentencing laws that he resigued from the bench in 1990. Alan Abrahamson, Judge Irving May Play Role in Suits Facing Lincoln S\&L, L.A. TMES, Dec. 7, 1990, at D1.

52. In many jurisdictions, the exhibition or use of a weapon in the commission of an offense effectively triples the punishment authorized for the underlying offense. See, e.g., FLA. STAT. ANN. $\S 775.087$ (West 1992) (seriousness of the offense increases by one degree, so that a 5-year penalty becomes a 15 -year penalty). In the aggregate, the disparity between sentences with and without mandatory enhancements is considerable. A study of ease dispositions in Arizona for the 12-month period between July 1,1989 , and June 30,1990 , showed that the average sentence imposed for 3,552 offenders without mandatory enhancements was 51.2 months, while the average sentence for 1,297 offenders with mandatory enhancements was 117.8 months. INSTITUTE FOR RATIONAL PUBLIC Policy, arizona Criminal Code and Corrections Study: Final Report to the LEGISLATIVE COUNCIL $\vee(1991)$. 
ment for persons sentenced with mandatory enhancements is normally longer than for other offenders because parole eligibility is eitlier delayed or denied. ${ }^{53}$

Mandatory punishment provisions also are likely to liave a substantial, though imdirect, impact on prison populations by giving prosecutors enormous plea bargaining leverage. ${ }^{54} \mathrm{~A}$ prosecutor can cliarge a severe sentence enhancement tliat a court must impose if a defendant is convicted at trial. The harsher tlie sentence the defendant risks by going to trial, the greater the prosecutorial power to dictate the terms of plea agreements. The prosecutor can thus force a defendant to plead guilty to more punitive terms than the defendant otherwise would have accepted. This use of statutory sentencing provisions as leverage in plea bargaining mdirectly leads to higlier percentages of defendants sentenced to prison, longer periods of imcarceration, and increased pressure on correctional resources. ${ }^{55}$

Legislatures have increased determinate sentencing ranges and liave enacted mandatory minimun sentencing statutes in response to political pressures from constituents. These changes embody legislative judgments about deterrence and severe, mandatory punishment. However, by their very nature they also affect and alter tlie processes of the criminal justice systein. Their influence and its implications are explored further in Part II.

II

Mandatory Punishment and Criminal Process

Herbert Packer observed a generation ago that the manner im which criminal cases are processed bears significantly on the wisdom of sentencing decisions. ${ }^{56}$ The converse of Packer's observation is also true. Sentencing policy sliapes the processing of criminal cases, particularly with regard to whether the defendant is given a fair opportunity to contest the allegations against her. By requiring courts to impose severe sentences in

53. Sentences imposed under the federal Anti-Drug Abuse Act of 1986 are illustrative. In 1984, two years before the statute was enacted, the median sentence for drug distribution was 36 months; the period of incarceration before parole eligibility was 12 months (one-third of the sentence). U.S. SENTENCING COMM'N, supra note 12, at 44 . In 1990, however, the median courtroom sentence for drug distribution was 66 months, and the defendant would likely serve $85 \%$ of the sentence, or 56 months. Id.

54. The prosecutor's plea bargaining leverage is greatest in charge-based sentencing systems. See infra text accompanying notes 102-05.

55. For an illustration in a hypothetical case, see infra text accoinpanying notes 57-67. If the defendant is convicted after trial, she faces a mandatory presumptive sentence of 19 years in prison without possibility of parole. The prosecutor could use the enhanceinents as powerful bargaining chips if the prosecutor offers to dismiss all of the sentence enhancement allegations in returu for a guilty plea with the stipulation that the defendant serve the presumptive prison term for robbery. This kind of plea bargaining illustrates the indirect impact of mandatory sentencing laws on prison populations.

56. Herbert L. Packer, Two Models of the Criminal Process, 113 U. PA. L. REv. 1, 1-2 (1964). 
certain circumstances, niandatory punishment statutes cast a long shadow over plea bargaining practices, factfinding procedures, and the scope of the Fourth Amendment exclusionary rule.

\section{A. Two Types of Sentencing: Charge-Based and Conduct-Based}

A jurisdiction's choice between charge-based and conduct-based sentencing in criminal prosecutions influences the interaction between mandatory sentencing provisions and the criminal process. In chargebased sentencing, the formal charges the state brings against the defendant must contain the factual allegations that trigger the inandatory minimum sentence. In conduct-based sentencing, the court imposes the enhanceinent sentence based on the defendant's actual conduct and criminal history, regardless of the charges for which she is convicted. ${ }^{57}$ The two approaches differ in the extent to which prosecutorial plea bargaining practices influence judicial sentencing discretion.

This is best illustrated by a hypothetical case. A defendant with two prior felony convictions is prosecuted for allegedly robbing an elderly victim. The prosecution also claims that the defendant displayed a gun during the robbery. The victim identifies the defendant's photograph, but the defendant has a credible alibi defense that might raise a reasonable doubt if the case goes to trial. The jurisdiction has statutes requiring punishment enhancelnents for repeat offenders, for offenses committed with guns, and for crimes against elderly victims.

In a charge-based sentencing jurisdiction, such as California, the court may not impose the sentence enhanceinents unless they are formally charged and are either proven at trial or admitted by the defendant. $^{58}$ The presumptive sentence for robbery in California is three years

57. For discussions of the distinction between conduct- and charge-based sentencing, sec PARENT, supra note 3, at 52-55 (describing the operation of and problems with the two approaches); Coffee \& Tonry, supra note 3, at 171-92 (discussing the impact of real offense sentencing across various fact patterns); Heaney, supra note 3, at 208-30 (noting the power of federal judges to enhance sentences for conduct that was not charged or was not proven beyond a reasonable doubt, and arguing that conduct should only be penalized if it was part of a criminal conviction); Barbara $S$. Meierhoefer, Individualized and Systemic Justice in the Federal Sentencing Process, 29 AM. CRIM. L. REV. 889, 893-95 (1992); Stephen J. Schulhofer, Due Process of Sentencing, 128 U. PA. L. REv. 733, 757-82 (1980) (noting that conduct-based sentencing limits the prosecutorial discretion found in charge-based sentencing guideline systcms); Louis B. Schwartz, Options in Constructing a Sentencing System: Sentencing Guidelines Under Legislative or Judicial Hegemony, 67 VA. L. REV. 637, 680-81 (1981) (noting the principles that are in tension in the debate between charge- and conduct-based sentencing); Michael H. Tonry, Real Offense Sentencing: The Model Sentencing and Corrections Act, 72 J. CRIM. L. \& CriminologY 1550 (1981) (objecting to the Model Sentencing Act's real offense sentencing because it violates accepted norms of criminal law and gives too much import to judge's perceptions of what really happened); Wilkins, supra note 4, at 576-77 (detailing U.S. Sentencing Commission's move toward a hybrid of charge- and conduct-based sentencing).

58. See, e.g., Cal. PeNal CODE $\S 667.9$ (West 1988). Originally, California Penal Code $\S 667$ was not construed to be mandatory for sentencing courts. People v. Fritz, 707 P.2d 833 (Cal. 1985). However, the California Legislature abrogated the holding in Fritz in 1986 by clarifying that the statute restricted the authority of the trial court to strike the prosecutor's allegation of a prior 
in prison..$^{59}$ If the defendant is convicted of a serious felony against an elderly victim, the court must add a two-year sentence enhancement for the age of the victim. ${ }^{60}$ If the defendant admits or the prosecution proves that the defendant has one or more prior convictions for serious felomes, the court must impose a five-year sentence enhancement for each prior conviction. ${ }^{61}$ Similarly, displaying a firearm in the commission of a felony, if admitted or proven at trial, results in an additional sentence enhancement of four years. ${ }^{62}$

As a result, if convicted of all the allegations at trial, the defendant faces a presumptive sentence of nineteen years in prison without discretionary parole release. Unless the defendant is acquitted, the prosecutor's charging and plea bargaining decisions effectively determine the sentence. By offering a dismissal of one or more of the enhancement allegations to induce a guilty plea, the prosecutor can fix the presumptive sentence at either seventeen, fifteen, fourteen, twelve, ten, seven, five, or three years in prison. ${ }^{63}$ Moreover, as the tariff of sentence enhancements becoines steeper and the prosecutor offers significant reductions, the defendant will be less likely to take the gamble of trying to raise a reasonable doubt at trial, despite the existence of an alibi defense.

In contrast, the sentence in a conduct-based sentencing system depends on the judge's findings made at the time of sentencing concerning the circumstances of the offense and the defendant's criminal history, without regard to whether allegations concerning these matters are included in the charging instrnment. In our hypothetical case, the indictment or infornation charges only the robbery offense. The prosecution need not charge separate allegations related to the gun, the prior convictions, and the victim's age. If the defendant is convicted of the robbery charge, the court must determine whether the enhancement circumstances related to the offense are true, even though the prosecutor has not charged them. The purest forn of conduct-based sentencing is an indeterminate system in which the court's sentencing options are not even limited by a statutory sentencing range for the specific offense of conviction. Thus, in our hypothetical case, if the defendant pleads guilty to the lesser included offense of theft in exchange for dismissal of the robbery charge, the court still inust determine if a robbery was committed. Even

conviction. See Career Criminal Punishment Act, ch. 85, § 3, 1986 Cal. Stat. 211, 211-12; see also People v. Jackson, 244 Cal. Rptr. 37, 39 \& n.4 (Ct. App. 1986) (decided before the revision of $\S 667$ and limiting the holding of Fritz).

59. Cal. Penal Code $\S 213$ (West Supp. 1992).

60. Id. $\S 667.9$ (a) (West 1988).

61. Id. $\S \S 667-667.9$.

62. Id. $\S 12022.5$ (a) (West Supp. 1992). The presumptive sentence is four years, with a range between three and five years. Id.

63. In addition, the prosecutor can offer to reduce the robbery charge to a lesser offense, further limiting the range of sentences available to the court. 
though the defendant has been convicted of the lesser offense, the sentence is based on the court's findings at the time of sentencing that in fact the defendant committed a robbery, used a gun to threaten an elderly victim, and had two prior convictions.

Although no jurisdiction uses a pure conduct-based sentencing system, the federal guidelines include both charge-based and conduct-based sentencing features. If our hypothetical robber is convicted in federal court, the starting point for determining the defendant's sentence is the base offense level of the charge of conviction. ${ }^{64}$ The court then calculates the actual sentence using a set of postconviction factual findings that include such matters as the use of a gun, the value of property taken, the age of the victim, and the defendant's prior record, even though no specific factual allegations concerning these matters have been proven at trial. $^{65}$

This approach gives federal prosecutors less bargaining leverage than their counterparts in states that rely more extensively on chargebased sentencing. Federal prosecutors cannot offer sentencing concessions on such matters as the defendant's prior convictions or the victim's age to induce a guilty plea. ${ }^{66}$ However, federal prosecutors still bargain effectively by offering charge reductions to lesser offenses, such as theft, which has a lower guidelines offense level than robbery, and consequently a lower punishment range. ${ }^{67}$ The federal system also delays the

64. There are 43 guideline offense levels, scaled according to the seriousness of each offensc in the federal criminal code. See U.S. SEnTEncing Comm'N, Federal Sentencing Guidelines MANuAL § 5A (1992) (Sentencing Table) [hereinafter Guidelines MANUAL].

65. Under the federal sentencing guidelines, the range of possible sentences for robbery, without consideration of aggravating circumstances or prior record, is 33 to 41 months. Id. $\S \S 2 \mathrm{B3} .1,5 \mathrm{~A}$. If the judge finds at the time of sentencing that the defendant displayed a firearm, the victim was elderly, and the defendant had served prison terms for his two recent felony convictions, the sentence range is 100 to 125 months. Id. $\S \S 2 \mathrm{B3} .1(\mathrm{~b})(2), 3 \mathrm{~A} 1.1,4 \mathrm{~A} 1.1,5 \mathrm{~A}$ (the "offense levcl" is raised from 20 to 27 because 5 points are added for displaying the firearm and 2 for harming a vulnerable victim; the "criminal history category" would be IV with 8 "criminal history points," 6 stemming from the two felony convictions and 2 from the recency of prior confinement).

66. With regard to the gun, federal prosecutors have a choice between charge-based sentencing and conduct-based sentencing. Possession of the gun in the commission of the robbery is a separatc federal offense, with a mandatory minimum five-year sentence. 18 U.S.C. $\$$ 924(c) (1988 \& Supp. I1I 1991). If the prosecutor charges this offense, it operates as a charge-based enhancement. However, even if the prosecutor does not charge the separate firearm count, the judge is required to take the gun into account when calculating the sentence for the robbery. See, e.g., United States v. Mocciola, 891 F.2d 13, 17 (1st Cir. 1989) (defendant's sentence was enhanced for possession of a weapon despite his acquittal on a separate weapons charge).

67. In the federal system, a plea agreement to reduce the offense from robbery to theft would result in a significant reduction in the maximum permissible sentence, even if the aggravating circumstances were taken into account. Under the federal sentencing guidelines, a plea to theft would reduce the base offense level of 20 (for robbery) to a base offense level of only 4 . However, the judge may accept such an agreement only "if the court determines, for reasons stated on the record, that the remaining charges adequately reflect the seriousness of the actual offense behavior and that accepting the agreement will not undermine the statutory purposes of sentencing." GUIDELINES MANUAL, supra note $64, \S 6 \mathrm{~B} 1.2(\mathrm{a})$; see infra text accompanying notes 140-47.

The federal prosecutor can also charge the defendant with the separate federal offensc of using a 
determination of disputed facts from the trial stage to a more informal sentencing hearing. The defendant at a federal sentencing hearing has no right to a jury trial, hearsay is admissible, and the government's evidentiary burden may be lower than at trial. ${ }^{68}$

No sentencing system rehes entirely on either charge-based or conduct-based sentencing alone. Courts in virtually all charge-based systems have at least a narrow range of sanctions from which to choose for each offense category or enhancement allegation; the aggravating or mitigating circumstances that the court finds at sentencing influence the choice of sanction. In a conduct-based sentencing system, the charge of conviction normally himits the range of sanctions available to the sentencer. Although each jurisdiction is unique in the extent to which it requires the inclusion of sentence enhancement allegations in charging documents, a dichotomy exists between state and federal practice. Most states utilize a strict charge-based approach for mandatory sentence enhancements, ${ }^{69}$ while federal courts follow a hybrid of charge-based and conduct-based sentencing. ${ }^{70}$ The consequences of this divergence are considered in the following subsections.

\section{B. The State Court Experience with Charge-Based Sentencing}

The combination of mandatory enhancements and charge-based sentencing gives state prosecutors enormous sentencing power because courts can consider leniency only if prosecutors permit it. ${ }^{71}$ The prose-

gun in commission of a robbery under 18 U.S.C. $\$ 924$ (c), which can then be bargained away. Under $\$ 924$ (c), the mandatory sentence is a five-year term to be served consecutively to the robbery term. This is substantially greater than the conduct-based guidelines enhancement for use of the gun. As such, it becomes a powerful and effective prosecutorial bargaining tool. See infra text accompanying notes $158-63$.

68. See infra text accompanying notes 185-203.

69. A number of states have explicit provisions to this effect. See, e.g., Cal. PENAL CodE $\S 667.9$ (c) (West 1988); ME. REv. STAT. ANN, tit. 17-A, $\S 1252(4)-(5)$ (West 1983); N.D. CENT. CODE $\S 12.1-32-02.1$ (1985).

70. See infra text accompanying notes 121-31. There are notable exceptions to this general dichotomy. For example, a Pennsylvania conduct-based sentencing statute provides that anyone convicted of certain felonies must receive a minimum sentence of five years imprisonment if the sentencing judge finds, by a preponderance of the evidence, that the person "visibly possessed a firearm" during the commission of the offense. 42 PA. CoNS. STAT. ANN. $\S 9712$ (a) (1982). This provision was upheld in McMillan v. Pennsylvania, 477 U.S. 79, 91,93 (1986). Additionally, states adopting guidelines sentencing systems generally determine a defendant's prior criminal history level at the time of sentencing, regardless of whether prior convictions are explicitly charged in the indictment. See, e.g., WASH. REV. CODE ANN. § 9.94A.110 (West Supp. 1992).

71. On the relationship between prosecutorial charging and plea bargaining discretion and sentencing power, sec Albert W. Alschuler, Sentencing Reform and Prosecutorial Power: $A$ Critique of Recent Proposals for "Fixed" and "Presumptive" Sentencing, 126 U. PA. L. REv. 550, 551 (1978) (arguing that this sentencing discretion "is concentrated in an inappropriate agency" and that the benefits of the prosecutor's sentencing discretion "are made available only to defendants who sacrifice their constitutional rights"); Terance D. Miethe, Charging and Plea Bargaining Practices Under Determinate Sentencing: An Investigation of the Hydraulic Displacement of Discretion, $78 \mathrm{~J}$. CRIM. L. \& CRIMINologY 155, 175-76 (1987) (concludimg from empirical research that "[e]ven 
cutor can then use this sentencing influence to deter defendants from exercising their right to a trial in which the state must prove guilt beyond a reasonable doubt. Prosecutors can charge mandatory enhancement allegations in all cases in which there is a factual basis for doing so, even when sufficiently mitigating circumstances indicate that the enhanceinent provisions should not be enforced. The mandatory sentencing consequences of a guilty verdict pressure defendants, who otherwise might test the state's evidence, into accepting guilty pleas. Indeed, a legislature can inake charge-based inandatory pumshment so commonplace and severe that few if any defendants will be willing to chance a trial.

Available evidence suggests that this is beginning to occur in states, like California, that have a large and growing number of harsh chargebased sentence enhancement statutes. ${ }^{72}$ The percentage of felony prosecutions resulting in guilty pleas in California counties is among the highest in the nation. ${ }^{73}$ Of course, factors unrelated to harsh charge-based inandatory punishment laws might have influence on these high guilty plea rates. Prosecutorial and judicial caseloads ${ }^{74}$ and cooperative relations between defense lawyers and prosecutors ${ }^{75}$ could also contribute to

when sentencing guidelines do not explicitly regulate prosecutorial discretion, various mechanisms of social control still operate to limit its use and possible abuse").

72. See, e.g., Cal. Health \& SAFETY CoDE $\$ \S 11370,11370.2, .4$ (West 1991) (mandatory sentence enhanceinents for various drug offenses); CAL. PENAL CODE $\S \S 667-667.9$ (a) (West 1988 \& Supp. 1992) (numerous provisions requiring consecutive sentences for prior convictions and prison terms); id. $\S 12022.6$ (West Supp. 1992) (inandatory consecutive sentence for taking, destroying, or damaging property in the commission or atteinpted commission of a felony offense); id. $\$ \S 12022.7$ .8 (mandatory consecutive sentences for inficting great bodily injury in the commission of an offense); id. $\S 12022.9$ (mandatory five-year consecutive sentence for assault causing termination of pregnancy); id. $\S 12022(\mathrm{a})(2)$ (consecutive three-year sentence for committing an offense while armed with an assault weapon); id. $\S 12022$ (b) (additional one-year sentencc for using a deadly weapon in the commission of an offense); id. $\S 12022$ (c) (presumptive four-year consecutive sentence for coinınitting a drug offense while armed with a firearm); id. $\$ 12022.1(\mathrm{~b})$, (e) (mandatory consecutive sentences for offenses committed while released froin custody for another offense).

73. See Bureau of Justice Statistics, U.S. Dep'T of Justice, The Prosecution of FeloNy ARRESTS, 1987, at 7 (1990) (showing that the guilty plea rate in San Diego and Riverside, California, were the highest of 31 jurisdictions in a national survey of felony dispositions; Los Angeles and Bakersfield, Califormia, were involved in a four-way tie for third).

74. The inost coinmonly offered explanation for plea bargaining is caseload pressure. See Santobello v. New York, 404 U.S. 257, 260 (1971) (plea bargaining necessitated by caseloads); People v. Griffth, 349 N.Y.S.2d 94, 97 (App. Div. 1973) (elinination of plea bargaining would result in "total breakdown" of court operations (quoting Harold A. Stevens, Little Concern or Support Seen for Needs of Courts, N.Y. L.J., May 1, 1973, at 25, 29)); MARTIN MAYER, THE LAWYERS 159 (1967) ("If even one percent of [New York city] arraignments were actually to proceed to a fullfledged trial, the systein would break down instantly."); Peter Arenella, Reforming the Federal Grand Jury and the State Preliminary Hearing to Prevent Conviction Without Adjudication, 78 Mich. L. REV. 463, 523-24 (1980) (criminal justice systein would collapse if inore defendants went to trial); Warren Burger, The State of the Judiciary-1970, 56 A.B.A. J. 929, 931 (1970) (small changes in guilty plea rates have a large impact on court resources); Welsh $\mathrm{S}$. White, $A$ Proposal for Reform of the Plea Bargaining Process, 119 U. PA. L. REV. 439, 440 (1971) (removing incentives to plead guilty would place an intolerable strain on the system).

75. Several observers lave depicted the crininal justice system as a bureaucracy through which lower-class persons are hustled expeditiously, "just as they are in health care, welfare, public 
the extensive plea bargaining in California.

However, an examination of trial rate changes occurring after the enactment of sentence enhancement legislation strongly supports the case for a causal relationship between severe charge-based mandatory punishment and the coercion of guilty pleas. Analysis of Arizona's trial rates before and after mandatory punishment legislation bears this out. The Arizona Legislature enacted a series of increasingly severe charge-based mandatory pumishment statutes from the mid-1970s to the mid-1980s. As detailed below, these statutes have effectively changed the nature of criminal process in that state.

In 1976, the Arizona Legislature passed a typical charge-based mandatory sentence enhancement law. Anyone found to have used a firearm while committing robbery, kidnapping, rape, various forms of aggravated assault, or resisting a police officer was no longer eligible for a suspended sentence, probation, parole, or other release froin custody before serving a mandatory prison sentence. ${ }^{76}$ The statute gave prosecutors a powerful new opportunity to induce guilty pleas by charging the firearm provision whenever a defendant was eligible, then offering to

housing, and other meeting grounds of poverty with bureaucracy." Lawrence B. Mohr, Organizations, Decisions, and Courts, 10 LAw \& Soc'y REv. 621, 621 (1976). Under this view, proseeutors cooperate with judges and defense lawyers to avoid conflict, reduce uncertainty, and maintain group cohesion. See James EISENSTEIN \& Herbert JaCob, Felony JusticE: AN ORGANIZATIONAL ANALYSIS OF CRIMINAL COURTS 19-38 (1977) (characterizing the relationships among the judge, prosecutor, and defense counsel as forming a work group with defined roles and authority relationships as well as common goals); MARCIA J. LIPETZ, Routine JUSTICE: Processing CASES IN WoMEN's CoURT 71 (1984) (proseeutors, public defenders, and court employees have negotiated a routine that promotes organizational and individual goals while minimizing sources of couflict); Peter F. NARdulli, The Courtroom Elite: AN Organizational Perspective on CRiminal Justice 66 (1978) (all organizationally oriented studies of criminal courts share the behief that judges, prosecutors, and defense counsel cooperate to pursue the common interest in processing cases expeditiously); George F. Cole, The Decision to Prosecute, 4 LAw \& Soc'y REv. 331, 332 (1970) (legal system may be viewed as a set of interorganizational exchange relationships in which the participants share a common territorial field and collaborate for different and particular ends); Malcolm M. Feeley, Two Models of the Criminal Justice System: An Organizational Perspective, 7 LAW \& Soc'y REv. 407, 415-16 (1973) (noting that all parties involved in the criminal justice process share an interest in guilty pleas); Maureen Mileski, Courtroom Encounters: An Observation Study of a Lower Criminal Court, 5 LAW \& Soc'Y REV. 473, 479 (1971) (in one court, 72\% of the cases are handled in one minute or less); Mohr, supra, at 638 (compatibility of judges', prosecutors', and defense attorneys' goals leads to plea bargaining); Peter F. Nardulli, The Caseload Controversy and the Study of Criminal Courts, 70 J. CRIM. L. \& CRIMINolOGY 89, 97 (1979) (judges, prosecutors, and defense attorneys have a common interest in processing cases expeditiously); Jerome H. Skolmick, Social Control in the Adversary System, $11 \mathrm{~J}$. CoNflict Resol. 52, 61 (1967) (most public defenders argue that cooperating with prosecutors produces better results for their clients).

76. Act of June 23, 1976, ch. 111, 1976 Ariz. Sess. Laws 438, 438-45. A 1974 statute had provided that anyone committing robbery while armed with a firearm was ineligible for probation. Act of May 13, 1974, ch. 144, § 3, 1974 Ariz. Sess. Laws 666, 667-68. The 1976 statute extended the scope of the 1974 law to include aggravated assault, kidnapping, resisting an officer, rape, and setting off an explosive device. Act of June 23, 1976, ch. 111, §§ 2-5, 7, 1976 Ariz. Sess. Laws 438, 439-42. In connection with rape prosecutions, the 1976 law applied to all dangerous weapons, not just guns. Id. § 5 , at $440-41$. 
TABLE 1

Felony Trial Rate, Maricopa County, Arizona Before and After SENTENCINg Law Changes ${ }^{77}$

\begin{tabular}{|c|c|c|c|c|}
\hline & Year & $\begin{array}{c}\text { Total Cases, } \\
\text { Trial or } \\
\text { Plea }^{78} \\
\end{array}$ & $\begin{array}{l}\text { Number } \\
\text { Going } \\
\text { to Trial } \\
\end{array}$ & $\begin{array}{c}\text { Percentage } \\
\text { Going to } \\
\text { Trial } \\
\end{array}$ \\
\hline (Before chauges) & 1976 & 3673 & 382 & 10.40 \\
\hline (1976 law in effect) & $\begin{array}{l}1977 \\
1978 \\
\end{array}$ & $\begin{array}{r}3639 \\
3384 \\
\end{array}$ & $\begin{array}{l}321 \\
293 \\
\end{array}$ & $\begin{array}{l}8.82 \\
8.66 \\
\end{array}$ \\
\hline $\begin{array}{l}\text { (Soine cases terminated } \\
\text { under } 1976 \text { law, some } \\
\text { under } 1978 \mathrm{Code} \text { ) }\end{array}$ & 1979 & 3812 & 244 & 6.40 \\
\hline $\begin{array}{l}\text { (First three full } \\
\text { years under } 1978 \text { Code) }\end{array}$ & $\begin{array}{l}1980 \\
1981 \\
1982 \\
\end{array}$ & $\begin{array}{l}3864 \\
5489 \\
4848 \\
\end{array}$ & $\begin{array}{l}219 \\
328 \\
267 \\
\end{array}$ & $\begin{array}{l}5.67 \\
5.98 \\
5.51 \\
\end{array}$ \\
\hline $\begin{array}{l}\text { (First four full years } \\
\text { under } 1982 \text { law) }\end{array}$ & $\begin{array}{l}1983 \\
1984 \\
1985 \\
1986\end{array}$ & $\begin{array}{l}4662 \\
4826 \\
5530 \\
6982\end{array}$ & $\begin{array}{l}208 \\
182 \\
238 \\
312\end{array}$ & $\begin{array}{l}4.46 \\
3.77 \\
4.30 \\
4.47\end{array}$ \\
\hline
\end{tabular}

\section{GRAPH 1}

Trial Rate inMaricopa County (Phoenix Area) After Legislative CHANGES INARIZONA SENTENCING LAW

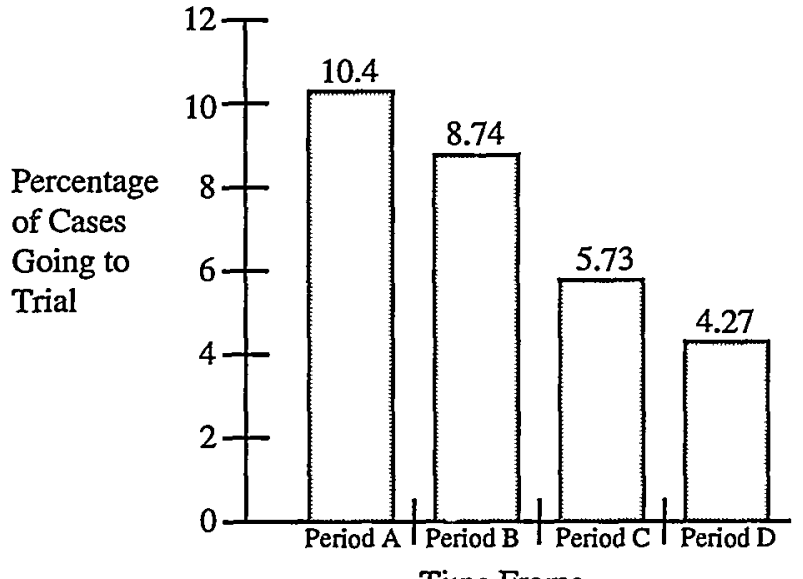

Key:

Tine Frame

Period A: Year Immediately Preceding 1976 Statute.

Period B: Two-Year Period Under 1976 Statute and Preceding 1978 Code.

Period C: First Three FuIl Years Under 1978 Code.

Period D: First Four Years Under I982 Amendment to 1978 Code.

77. Data were gathered from Maricopa County Superior Court Records by the author and his research assistants (notes on file with author).

78. This excludes cases that were dismissed. 
dismiss it in return for a plea. Immediately after the statute went into effect the guilty plea rate in the state's largest court systein increased significantly. ${ }^{79}$ As shown in Table 1 and Graph $1,10.40 \%$ of criminal cases proceeded to trial in 1976 , the calendar year immediately preceding the effective date of the new law. During the following two years, while the new law was in effect, the trial rate fell to $8.74 \% .^{80}$

The Arizona Legislature enacted a new criminal code in 1978 that superseded the 1976 mandatory sentencing law. The new code mcluded two groups of exceptionally severe charge-based sentence enhancement provisions that are still in effect today. ${ }^{81}$ The first group requires long prison terms for persons convicted of "dangerous" offenses, defined as felonies in which the offender either inflicts serious physical injury or uses a weapon or other dangerous instrument. ${ }^{82}$ These provisions are far broader in scope than the 1976 law because the 1976 law applied only to firearms and was limited to certain enumerated felomes. The second group of enhancement ineasures provide that "repetitive" felony offenders are not eligible for probation or a suspended sentence, and their release from prison is delayed until they have served substantially enlianced terms. ${ }^{83}$ Moreover, if the state consolidates into one prosecution two or more charges based on offenses committed on separate occasions, the state has discretion to count one of the offenses as a prior conviction. As such, it triggers a repetitive offender enhanceinent for the second offense. ${ }^{84}$

79. The trial rates discussed in the text are based on criminal prosecutions in the Maricopa County Superior Court, which serves the Phoenix metropolitan area.

80. $Z=2.823, p<0.005$.

81. The Arizona Legislature appointed a commission to study the state's sentencing laws. The commission conducted a study based on the sentences imposed in 15,720 felony cases and found that the average length of time actually served in prison by persons sentenced under the mandatory sentencing provisions of the 1978 Code is more than twice the time served by those who are not sentenced under these provisions. INSTITUTE FOR RATIONAL PUBL1C POLICY, supra note 52, at 3334. The commission recommended an overhaul of the state's sentencing practices. $I d$. at vii-xi.

82. ARIZ. REV. STAT. ANN. § 13-604(F)-(G) (1989).

83. Id. § 13-604(A)-(C).

84. Id. $\$ 13-604(\mathrm{H})$. The Arizona Supreme Court has held that the conviction used to invoke the enhancement provisions may occur either before or after the to-be-enhanced offense, so long as the two offenses are committed on separate occasions. See State v. Hannah, 617 P.2d 527 (Ariz. 1980) (a prior felony conviction may be used for enhanced punishment even if prior conviction occurs after commission of principal offense). Contemporary, current convictions also serve as "prior" offenses for sentence enhancement purposes in a few other states. See Conley v. State, 612 S.W.2d 722, 726 (Ark. 1981) (holding that a prior conviction counted against defendant in sentencing where the act on which the earlier conviction was based preceded the act currently the subject of sentencing); State v. Hernandez, 311 N.W.2d 478, 481 (Minn. 1981) (holding that, where a defendant is convicted at one hearing for crimes committed on three separate occasions, the convictions for the earlier committed crimes can be used to enhance the sentence for those cominitted later); Jordan v. State, 383 So. 2d 495, 497 (Miss. 1980) (holding that prior convictions could be considered in the sentencing for a later conviction even if the prior convictions occurred after the commission of the offense leading to the later conviction).

An analogous rule applies in the federal courts. A first conviction for the use of a firearm in the 
Together, the dangerous and repetitive offender provisions potentially affect more than half the felony cases in Arizona. ${ }^{85}$ The recent prosecution of a Phoenix house painter illustrates the effectiveness of these provisions in coercing guilty pleas. The state charged the painter with selling small quantities of marijuana to an undercover agent on two occasions. ${ }^{86}$ The painter insisted that he was innocent, the victim of a misidentification. ${ }^{87}$ Absent inandatory sentencing laws, he probably would have gone to trial to contest his guilt. If convicted, he would not have beell a likely candidate for a prison sentence because the chargcd offenses were not especially serious, he had no prior criminal record and he supported a pregnant wife and three children. However, under Arizona's sentencing framework, the prosecutor charged him as a repetitive offender. A couviction carried a mandatory prison sentence with a presumptive term of seven and a half years. The state later offered to dismiss the repetitive offender allegation if he would plead to a lesser offense with a short jail term and probation. ${ }^{88}$ Although he continued to assert his innocence, he accepted the offer. ${ }^{89}$

Prosecutors appear to use the dangerous and repetitive offender provisions frequently as plea bargaining chips by charging defendants with seitence enhancement allegations, only to dismiss them later. In a recent year, for exainple, prosecutors dismissed repetitive offender allegations in $76 \%$ of all cases in which they were initially alleged, and dangerous felony allegations $77 \%$ of the tine. ${ }^{90}$ Although some of these dismissals

commission of a violent or drug offense requires a minimum consecutive sentence of five years in prison. 18 U.S.C. $\$ 924$ (c) (1988 \& Supp. III 1991). A second conviction carries a minimum consecutive sentence of 20 years. Id. A number of courts have interpreted the statute to require stacking of the mandatory penalties when the defendant is convicted of multiple counts under \$ 924(c), even if alleged in the same indictment. See, e.g., United States v. Rawlings, 821 F.2d 1543, 1546 (11th Cir.) (imterpreting an earlier version of $\$$ 924(c) and holding that where defendant is convicted at one hearing for two separate armed robberies, the gun enhancement provision can be applied as if defendant were a repeat offender), cert. denied, 484 U.S. 979 (1987).

85. Of 15,720 felony cases in Arizona between July 1, 1989, and June 30, 1990, the defendant was factually eligible for repetitive offender status in 7472 instances (47\%). INSTITUTE FOR Rational Public Policy, supra note 52, at 26. The defendant was factually eligible for dangerous offender status in 2148 cases (14\%). Id. at 27 . There was overlapping eligibility for repetitive offender and dangerous felony status in 872 cases. Id. at 28 . Thus, in $56 \%$ of all felony cases ( $(7472$ $+2148-872) / 15,720)$, the defendant qualified for a mandatory sentence enhancement if the prosecutor chose to charge it.

86. The painter's case is described in a newspaper article co-authored by his lawyer. See Nicholas Hentoff \& Christopher Johns, Packing Them In, ARIz. REPUBLIC, July 21, 1991, at C1.

87. The defendant consistently averred his innocence after he was arrested for the two sales. Interview with Nicholas Hentoff, attorney for the painter, in Phoenix, Ariz. (Feb. 2, 1992) [hereinafter Hentoff Interview].

88. The proposed plea agreement also called for community service and a stiff fine. Hentoff \& Johns, supra note 86 , at $C 2$.

89. Hentoff Interview, supra note 87 . The defendant was required to serve three months in county jail as a condition of probation. $I d$.

90. From 1989 to 1990 , repetitive offender charges were alleged in 3975 cases. Of these, defendants were convicted with the enhancement in 939 cases. INSTITUTE FOR RATIONAL PUBLIC 
may have been related to the sufficiency of the state's evidence, most reflected plea bargaining concessions. ${ }^{91}$

Not surprisimgly, the percentage of cases proceeding to trial decreased sharply after the 1978 Code went into effect. As illustrated in Graph 1, the average trial rate in the state's largest trial court was $8.74 \%$ during the two years immediately preceding the implementation of the new sentencing provisions. However, the average percentage of cases going to trial dropped to $5.73 \%$ during the first three full years of sentencing under the new code. ${ }^{92}$ This rate remained fairly constant until 1982, when the Legislature enacted another charge-based mandatory enhanceinent law that increased prosecutors' discretionary sentencing influence.

The 1982 law altered the sentencing of persons convicted of felomes while on probation or parole. If a parolee or probationer is convicted of a felony drug offense or a dangerous felony offense, the original parole or probation must be revoked. ${ }^{93}$ Additionally, the statute requires a sentence of life imprisonment for the new offense with no ehigibility for release from confinement for twenty-five years. ${ }^{94}$ A person convicted of any other felony while on probation or parole loses probation or parole status, must be sentenced to an enhanced term im state prison, and is not eligible for release durimg the sentence. ${ }^{95}$ The prosecutor invokes these provisions by mcluding in an indictment or information a separate allega-

Policy, supra note 52, at 27. Dangerous offender enhancements were alleged in 1232 cases, but the defendant was convicted with this enhancement in only 285 cases. Id. at 28.

91. In a forthcoming paper, I discuss a study I am conducting of lawyer-client interactions in 162 felony cases that were prosecuted in the Phoenix metropolitan area. The study is based on court records in the cases, as well as individual interviews with each of the defendants and most of the lawyers. Court records indicate that the prosecutor mitially charged and later dismissed mandatory sentence allegatious in over 100 of the cases. Of these, less than $20 \%$ were dismissed for evidentiary rcasons, according to defense counsel. In a majority of cases, the prosecutor agreed to disiniss allegations triggering mandatory sentences in return for a guilty plea to lesser charges. Records on file with author.

92. This difference is statistically significant. $Z=8.3611, p<0.005$. The 1978 Code applied to all offenses committed on or after October 1, 1978. Act of May 31, 1977, ch. 142, $\$ 188,1977$ Ariz. Sess. Laws 678, 800. As in most other jurisdictions, Maricopa County Superior Court records are conniled by identifying cases that have been terminated in court each month. Almost all of the felony cases that were terminated in the Maricopa County Superior Court during calendar year 1978 were prosecuted under the old code. Some of the cases terminated during the first half of 1979 were prosecuted under the old code, while others were prosecuted under the new code. Therefore, calendar year 1979 is not a useful year for assessing the effects of the new code on plea bargaining. Graph 1 compares the trial rate for the last two calendar years in which virtually all cases were terminated under the old code (1977 and 1978) with the first three calendar years in which virtually all cases were terminated under the new code (1980-1982). The trial rate dropped from $8.74 \%$ during the last two years under the old code to $5.73 \%$ for the first three years under the new code. Interestingly, as shown in Table 1, the trial rate for 1979 , the "mixed" code year, was $6.40 \%$. This rate is consistent with the theory that the new code had an immediate and dramatic effect on the incidence of plea bargaining.

93. ARIz. Rev. StAT. ANN. § 13-604.02(A) (1989).

94. Id.

95. Id. § $13-604.02(\mathrm{~B})$. 
tion that the defendant was on probation or parole at the time of the offense. If the prosecutor later amends the charging document to delete the allegation as part of a plea agreement, the defendant no longer receives the sentence enhancement.

State v. Barger ${ }^{96}$ demonstrates the harsh effects of the 1982 legislation. Barger, a parolee, struck his former landlady with his hand after she had tried to spray him with a garden hose outside her house. ${ }^{97} \mathrm{~A}$ friend of the landlady witnessed this, grabbed a machete, stepped toward Barger, and demanded that he leave. Barger then obtamed a pistol from another person at the scene, brandished it, and threatened to kill the landlady. No shots were fired, no one was physically injured, and Barger soon left.98 His troubles, however, had just begun.

The local prosecutor charged Barger with committing two dangerous offenses (aggravated assault) while on parole and a jury found him guilty of one of the counts despite a claim of self-defense. ${ }^{99}$ Barger received the required sentence under the 1982 statute: a mandatory term of life imprisonment, with no eligibility for release for twenty-five years. ${ }^{100}$ In upholding the sentence, the appellate court noted the trial judge's frustration over statutes that gave prosecutors the power to shape sentences by their charging decisions, "regardless of [the] experience or motive" of the prosecutor. ${ }^{101}$

Although Barger risked a trial under the 1982 law, other defendants

96. 810 P.2d 191 (Ariz. Ct. App. 1990).

97. Id. at 193.

98. Id.

99. Id.

100. Barger was charged under ARIz. REv. STAT. ANN. § 13-604.02 (1989), which requires a life sentence if a dangerous offense is committed while the offender is on release from confinement for another offense. Aggravated assault, a violation of ARIz. REV. STAT. ANN. $\S 13-1204$ (1989), is a dangerous offense when it involves the "exhibition of a deadly weapon." Id. $§ 13-604(\mathrm{~F})$.

101. Barger, 810 P.2d at 197. The trial judge addressed the defendant at the time of sentencing: Mr. Barger, I am inclined to agree with your attorney that under all the circumstances of this case, the sentenee that I am required to impose by law is wholly inappropriate. Unfortunately, there is not a thing in the world I can do about it other than state on the record that under no circumstances, even if the court had discretion, would I ever impose a sentence this severe for the actions that you took on that date.

$\cdots$

I have seen many cases where the aggravated assaults were far more serious than what you did, and the punishment was far, far less. The prosecutors do this every day. I don't know why this was prosecuted this way, but they have the discretion to prosecute you in the way that they see fit, and this Court doesn't have any discretion in what it has to do. Id. at 197-98.

In upholding the sentence, the appellate court expressed its own misgiving over a potential separation-of-powers issue:

[T]oday we express our concern that a junior officer in the executive branch of county government (deputy county attorney) is given great discretion and power to affect sentencing in a state court while denying to the state judicial officer who presides over that court any discretion in what has traditionally and inherently been a function of the court. Id. at 198. Separation-of-powers challenges to similar sentencing schemes in other jurisdictions have failed. See cases cited infra note 307. 
were more cautious. The percentage of cases gomg to trial in Maricopa County declined sharply after 1982 . In the three years immediately preceding the implementation of the 1982 law, the trial rate had been $5.73 \%$. This figure fell to $4.27 \%$ during the four years immediately after the 1982 law went into effect. ${ }^{102}$ While the 1982 statute may not have been the sole cause of this statistically significant decline in the trial rate, the bargaining leverage it granted prosecutors suggests that it was the primary cause. Defense attorneys claim that prosecutors "routinely" invoke the threat of mandatory sentences to deter defense counsel from filing pretrial motions, as well as to pressure defendants into plea agreements. ${ }^{103}$ The substantial deterrent effect of such threats is sufficient to cause the trial rate to drop significantly. In less than a decade the criminal trial rate was reduced from $10.40 \%$ to $3.77 \% .{ }^{104}$ During the same period, judicial, prosecutorial, and pubhic defender resources increased at a greater rate than the court's caseload. ${ }^{105}$ This suggests that the decline in the trial rate caimot be attributed to caseload pressure.

Reducing trial rates may be teinpting to pohicyınakers facing annual budget deficits, but such savings are illusory. As noted earher, the same mandatory sentence laws that induce guilty pleas have contributed substantially to recent increases in the cost of correctional services as prison populations have multiphed. ${ }^{106}$ Thus the fiscal consequences of chargebased mandatory pumshment statutes are probably greater than legislatures anticipated. Additionally, nonmonetary costs must be considered. Highly punitive mandatory sentencing laws that coerce guilty pleas threaten the continuing vitality of the Sixth Amendment right to trial. In many cases, legitimate doubts exist before trial concerning the defendant's guilt. The availability of a jury trial as a public forum to resolve those doubts serves the public, as much as the defendant, by legitimizing

102. See supra Table 1. $Z=6.3755, p<0.005$. The 1982 statute applied to offenses committed on or after July 24,1982 . Thus, almost all of the cases terminated in superior court during calendar year 1982 were prosecuted under the law existing before the 1982 statute went into effect. Almost all of the cases terminated in calendar 1983, however, were commenced after the effective date of the 1982 law.

103. Hentoff \& Johns, supra note 86, at C2; see also MiLton HeUMaNN, Plea BargalN1NG: The EXPeriences of Prosecutors, Judges, AND Defense ATtorneys 61-66 (1977) (prosecutorial "sanctions" against defense lawyers increase when defense counsel file adversarial pretrial motions).

104. The $10.40 \%$ rate refers to 1976 , while the $3.77 \%$ rate refers to 1984 . See supra Table 1.

105. The annual caseload of the Maricopa County Superior Court imcreased by $14 \%$ during the period of 1975 to 1984 . During the same period, the number of Superior Court judges increased by 46.8\%. Administrative OfFice OF THE Superior CoURT, Maricopa County Superior COURT HISTORY BOOK 112 (1990). The number of prosecutors in the County Attorney's Office increased by $43 \%$ between 1975 and 1984. Compare 1975 MARICOPA COUNTY ATTORNEY, ANNUAL REPORT with 1984 MARICOPA COUNTY ATrORNEY, ANNUAL REPORT. During the same years, the number of public defenders available for felony assignments incrcased by $45.8 \%$. Compare 1975 Maricopa Pub. Defender, ANnUal Report with 1984 Maricopa Pub. DEFENDER, ANNUAL, REPORT.

106. See supra Section I.C. 
the imposition of criminal punishment. When the risk of going to trial is so great that defendants are rarely willing to risk a trial, the values the Sixth Amendment seeks to protect are undermined.

\section{The Federal Hybrid of Charge-Based and Conduct-Based Sentencing}

Like most state legislatures, Congress has recently enacted inany statutes that establish mandatory minimum sentences and prohibit courts from suspendimg sentences or placing defendants on probation. ${ }^{107}$ The large majority of these provisions target violations of a few statutes relating to drug trafficking and one concerning firearms. ${ }^{108}$ The drug provisions require substantial prison terms for importation, nuanufacturing, distribution, and possession of narcotics or controlled substances. In most cases the weight of a substance containing drugs determines the sentence. ${ }^{109}$ For example, the minimum sentence for possession with intent to distribute five kilograms or more of a mixture containing a detectable amount of cocaine is ten years in prison for a first offender. If the defendant has one prior drug conviction, the niandatory minimuin sentence increases to twenty years. If the defendant has two or more prior convictions, the sentence is life imprisonment. ${ }^{110}$

Anotlier federal provision requires a five-year minimum sentence for possessing in excess of five grams of crack cocaine, without regard to whether the defendant intends to distribute the drug. ${ }^{111}$ The firearms provision is similar; it requires consecutive sentencing for the possession or use of a gun in the commission of violent crimes and drug offenses. ${ }^{12}$ The mandatory minimum punishment is five years in prison for a first offense and twenty years for each subsequent offense. ${ }^{13}$

Unlike most state enhanceinent laws, federal mandatory mininum sentence statutes are enforced in conjunction with intricate sentencing

107. In August 1991, the U.S. Sentencing Commission identified approximately 100 separate mandatory minimum penalty provisions located in 60 different federal statutes, with about 30 bills with similar provisions pending before Congress. U.S. SENTENCING COMM'N, supra note 12, at 10, 13.

108. Ninety-four percent of the 59,780 federal defendants sentenced pursuant to mandatory minimum sentence provisions between 1984 and 1990 involved violations of only four statutes relating to drug distribution and possession of firearms in the commission of other offenses. Id. at 10.

109. See 21 U.S.C. $\$ 841$ (b)(1)(A)-(B) (1988 \& Supp. III 1991) (establishing penalties for manufacturing, distributing, or possessing with intent to distribute, mixtures or substances containing detectable amounts of various controlled substances, with penalties determined by weight); id. $\S 960$ (1988) (establishing penalties for importing and exporting controlled substances).

110. Id. $\$ 841(\mathrm{~b})(1)(\mathrm{A})(1988$ \& Supp. III 1991). The mandatory minimum sentence for possession with intent to distribute between 500 grams and 5 kilograms of cocaine is 5 years for a first offense and 10 years for subsequent offenses. Id. $\S 841(\mathrm{~b})(1)(\mathrm{B})$.

111. See 21 U.S.C. § 844(a) (Supp. III 1991).

112. 18 U.S.C. $\S 924(c)$ (1988 \& Supp. III 1991).

113. Id. 
guidelines. The federal enhancement laws and sentencing guidelines went into effect at approximately the same time ${ }^{114}$ and each has influenced the other. The federal guidelines include detailed procedural requirements for calculating sentences in individual cases within the sentencing parameters set by Congress. ${ }^{115}$ In most instances, guidelines sentencing ranges closely track the gradations set forth in federal mandatory minimum sentence statutes. ${ }^{116}$ Commentators have often criticized the guidelines, not ouly for their severity and rigidity, but also for their contribution to the problem of prison overcrowding. ${ }^{117}$ However, the harshness of federal sentencing derives not just from the guidelines theinselves,

114. The principal federal mandatory minimum sentence provisions were enacted or expanded in 1984, 1986, and 1988. See supra note 9. The Federal Sentencing Reform Act of 1984 establislied the United States Sentencing Commission as an independent agency of the judicial branch and directed the Colnmission to prolnulgate sentencing guidelines for district court judges to follow. See 28 U.S.C. $\S 994$ (1988). The guidelines went into effect on Noveinber 1, 1987. GuideliNes MANUAL, supra note 64 , at 1 . However, many courts initially lield the guidelines unconstitutional, and thus they were not applied in all federal districts until February 1989, when the Supreine Court upheld their constitutionality in Mistretta v. Umited States, 488 U.S. 361 (1989).

115. See, e.g., GuIDELINEs MANUAL, supra note 64 , $\S 3$ A1.1-3E1.1 (sentencing adjnstments for victim-related factors, role in the offense, obstruction, multiple counts, and acceptance of responsibility).

116. See, e.g., infra notes $150-57$ and accoinpanying text.

117. See, eg., Federal Courts Study Comm., Report of the Federal Courts Study COMMITTEE 137 (1990) (federal judges and lawyers repeatedly coinplain of the guidelines' undue rigidity); $i d$. at 142 (Statennent of Honorable Judith N. Kecp) (the guidelines do not permit sentencing consideration of personal factors relating to individual defendants); Alscliuler, supra note 3 , at 915-24, 929-34 (rigidly using aggregation of liarms under the guidelines to determine sentences forces courts to impose tle same sentences on offenders of differing culpability); Freed, supra note 3 , at 1690, 1730-40 (U.S. Sentencing Commission proinulgated guidelines that are unnecessarily rigid, coinplex, and severe; appellate courts lave been unduly rigid in interpreting the guidelines); Heaney, supra note 3, at 164 (the guidelines result in unwarranted disparities, the average time served under guidelines sentences is twice as long as pre-guidelines averages, and fewer defendants are eligible for probation); Marc Miller, True Grid: Revealing Sentencing Policy, 25 U.C. DAvis L. REv. 587 (1992) (guidelines sentencing grid was not mandated by Congress, is too coinplex, and hides policy decisions); Charles J. Ogletree, $\mathrm{J}_{\mathrm{r}}$, The Death of Discretion? Reflections on the Federal Sentencing Guidelines, 101 HARV. L. REV. 1938, 1952-55 (1988) (the guidelines take insufficient account of differences in offenders or their inpact on prison overcrowding); Scliulhofer, supra note 3, at 851-70 (tlie federal guidelines result in excessive uniformity in sentencing); Gerald F. Uelmen, Federal Sentencing Guidelines: A Cure Worse than the Disease, 29 AM. CRIM. L. REV. 899, 905 (1992) (the guidelines are unnecessarily coinplex and confusing, resulting in a "federal bureaucracy" of sentencing); Owen S. Walker, Litigation-Enmeshed Sentencing: How the Guidelines Have Changed the Practice of Federal Criminal Law, 25 U.C. DAvis L. REv. 639, 647 (1992) (unforeseen byproduct of the guidelines is a dramatic increase in appellate litigation contesting sentences inposed by district courts); Jack B. Weinstein, A Trial Judge's First Impression of the Federal Sentencing Guidelines, 52 ALB. L. REV. 1, 14-29 (1987) (the guidelines are likely to canse a great increase in prison population).

Others have defended the federal sentencing guidelines. See, e.g., Joe B. Brown, The Sentencing Guidelines Are Reducing Disparity, 29 AM. CRIM. L. REV. 875 (1992) (sentencing disparity reduced under tlie guidelines); William W. Wilkins, Jr., Response to Judge Heaney, 29 AM. CRIM. L. REV. 795, 808-20 (1992) (Sentencing Commission's study of sentencing under the guidelines shows disparity reduced from pre-guidelines levels); Ronald F. Wriglit, Complexity and Distrust in Sentencing Guidelines, 25 U.C. DAVIS L. REV. 617 (1992) (complexity of tle federal guidelines serves policies of rational sentencing and limiting prosecutorial discretion). 
but in large part from the interaction between the guidelines and the inandatory minimum sentencing scheine enacted by Congress. ${ }^{118}$

\section{Guideline Implementation of Federal Mandatory Punishment Statutes}

The United States Sentencing Commission desigued the procedural frainework of the guidelines to best assure that all defendants who qualify for mandatory sentence enhanceinents receive those sentence enhanceinents. The guidelines also include several measures that seek to avoid the prosecutorial control of sentencing that occurs in state courts. The Commission utilized two inethods to achieve these goals. First, three guidelines provisions require conduct-based sentencing. ${ }^{119}$ Second, the guidelines' grading of aggravating circuinstances-particularly in connection with drug offenses-closely corresponds to the inain provisions of existing inandatory minimuin punishment laws. ${ }^{120}$

\section{a. The Use of Conduct-Based Sentencing Provisions to Enforce Mandatory Minimum Penalties}

Under the guidelines, the district court begins its sentencing calculations by determining the base offense level of the offense of conviction. ${ }^{121}$ The court determines the base offense level for drug offenses by its finding concerming the weight of the drugs. ${ }^{122}$ Findings of fact concerning specific offense characteristics, such as possession of a weapon, increase the offense level. ${ }^{123}$ The court also adjusts the offense level for such fac-

118. See infra text accompanying notes $150-53$ (how the guidelines and mandatory minimums lead to harsh sentences). At least one commentator has noted that an analysis of the federal guidelines must take into account the influence of statutory mandatory minimum sentence provisions. See Joseph F. Weis, Jr., The Federal Sentencing Guidelines-It's Time for a Reappraisal, 29 AM. CRIM. L. REV. 823, 824 (1992) (some of the inequities attributed to the guidelines are actually caused by mandatory minimums).

119. See Guidelines MaNual, supra note 64, $\$ \$ 1 B 1.3,6 \mathrm{~B} 1.2(\mathrm{a}), 6 \mathrm{~B} 1.4(\mathrm{a})$ (dealing respectively with defendant's acts and omissions, the seriousness of the offense behavior, and relevant facts and circumstances of the offense). Several courts have concluded that certain of thc guideline provisions serve to mitigate the disparate effects of charge bargaining. See United States v. Fernandez, 877 F.2d 1138, 1144-45 (2d Cir. 1989) (adherence to "real offense' sentencing" may undercut " "charge bargaining" "); United States v. Wright, 873 F.2d 437, 440-41 (1st Cir. 1989) (as a result of guidelines, charge bargains are no longer of much value to defendants in drug cases). Whether this conclusion is justified is highly debatable. See infra text accompanying notes 256-59.

120. See infra notes $150-52$ and accompanying text.

121. The court's first task under the guidelines is to determine the appropriate offense guideline section from Chapter Two of the Guidelines Manual. See Guidilines MANUAL, supra note 64, $\S \S 1 \mathrm{~B} 1.1, .2$. Each offense guidelines section has a base offense level corresponding to the seriousness of the offense of conviction; there are 43 offense levels. Id. $\$ 5 \mathrm{~A}$ (Sentencing Table).

122. Id. $\S 2 \mathrm{D} 1.1$. The offense levels for drug offenses correspond to the requirements of federal mandatory minimum sentence statutes. See infra text accompanying notes 150-57.

123. For example, the offense level for drug offenses is increased by two levels if the defendant possessed a dangerous weapon during commission of the offense. GUIDELINES MANUAL, supra note 64, § 2D1.1(b)(1). 
tors as the defendant's role in the crime and the defendant's awareness that the victim was unusually vulnerable because of age or physical or mental condition. ${ }^{124}$ The court then makes findings concerning the defendant's criminal history ${ }^{125}$ and identifies the appropriate sentencing range from the Guidelines Sentencing Table by reference to the defendant's adjusted offense level and criminal history. ${ }^{126}$ Finally, the court imposes a sentence within the appropriate range unless it finds a specific ground for departure. ${ }^{127}$

An important part of this scheine is guidelines $\S 1 \mathrm{~B} 1.3$, which addresses conduct-based sentencing. This provision instructs the court to determine the defendant's base offense level, specific offense characteristics, and adjustments to the offense level based on the defendant's "relevant conduct." 128 Relevant conduct for sentencing includes: (1) all acts or ornissions occurring during commission of the offense, in preparation for the offense, or in the course of attenpting to avoid detection of the offense; and (2) all acts or omissions in connection with offenses that were part of the same course of conduct or common scheme or plan. ${ }^{129}$ This requires a court to determine at the tinne of sentencing if a firearm was used in the commission of an offense, regardless of whether the defendant has pled guilty to, or has been found guilty of, using a firearm. ${ }^{130}$ Section 1B1.3 also requires the district court to look beyond the offense of conviction to crimes committed on other occasions, if together with the offense of conviction, they formed a common scheme or plan. In drug cases, this requires the court to aggregate the weight of drug substances, even when the defendant has not been convicted of possess-

124. Id. $\S \S 3 \mathrm{~A} 1.1,3 \mathrm{~B} 1.1$. The court also adjusts the offense level downward if the defendant has demonstrated an acceptance of responsibility for the offense. Id. § 3E1.1.

125. Id. § 4A1.1.

126. Id. § 5A (Sentencing Table).

127. Id. $\S 1 \mathrm{~B} 1.4$. The principal grounds for departure from applicable guidelines ranges are set forth in $\S \S 5 \mathrm{~K} 1.1,5 \mathrm{~K} 2.0$. The first of these provisions permits the court to depart from the guidelines on motion by the government stating that the defendant has provided substantial assistance in the investigation or prosecution of another person. $I d$. $\S 5 \mathrm{~K} 1.1$. The second provision permits a departure if the court finds " 'that there exists an aggravating or mitigating circumstance of a kind, or to a degree, not adequately taken into consideration by the Sentencing Commission in formulating the guidelines that should result in a sentence different from that described." "Id. $\S 5 \mathrm{~K} 2.0$ (quoting 18 U.S.C. $\S 3553(b)$ (1988)).

128. Id. § $1 \mathrm{~B} 1.3$.

129. Id.

130. A number of courts have held that sentence enhancements based on a judge's finding that the defendant possessed a firearm are constitutionally permissible even when the defendant has been acquitted of a charge under 18 U.S.C. $\$ 924$ (c). See, e.g., United States v. Rodriguez-Gonzalez, 899 F.2d 177, 179-82 (2d Cir.) (double jeopardy not violated when defendant's sentence is enhanced on the basis of conduct for which defendant has been aequitted), cert. denied, $111 \mathrm{~S}$. Ct. 127 (1990); United States v. Moceiola, 891 F.2d 13, 17 (1st Cir. 1989) (defendant acquitted of violating $\S 924(c)$, but sentence still enhanced for possession of a firearm); United States v. Juarez-Ortega, 866 F.2d 747, 749 (5th Cir. 1989) (defendant's punishment enhanced by sentencing departure based in part on defendant's possession of a firearm in the commission of the offense, even though defendant aequitted of violating $\S 924(\mathrm{c})$ ). 
ing or distributing some of those substances. ${ }^{131}$

United States v. Silverman ${ }^{132}$ illustrates how application of the relevant conduct proviso can enhance a sentence significantly. Silverman pleaded guilty to possession with intent to sell 52.9 grams of cocaine. ${ }^{133}$ This amount was approximately one tenth the 500 grams that triggers a inandatory five-year sentence. ${ }^{134}$ Silverman's offense carried a guideline range sentence of twenty-one to twenty-seven inonths incarceration. ${ }^{135}$ However, the presentence investigation report disclosed that a confidential informant told DEA agents investigating Silverman's case that Silverman was the head of a cocaine trafficking ring. The informant also stated that Silverman had supplied the informant with a kilograin of cocame several months before the current offense. The district court found that this information deinonstrated a common scheine or plan under $\S 1 B 1.3$. The court then added the kilogram to the 52.9 grains and sentenced Silverman to eighty-seven months in prison. ${ }^{136}$ The court thus applied the mandatory sentence statute despite the U.S. Attorney's decision not to seek a conviction for the alleged one-kilogram transaction. ${ }^{137}$

Silverman deinonstrates low $\S 1 \mathrm{~B} 1.3$ constrains federal prosecutors from using mandatory minimum sentence statutes in drug cases to induce guilty pleas. Assume that the government liad sufficient cvidence of the alleged one-kilogram sale to the informant to proceed with a prosecution of that charge. ${ }^{138}$ A plea agreement including a government promise not to charge the one-kilogram sale would liave been of little value if the court was required to enhance the defendant's punishment even in the absence of formal cliarges. Thus, judicial use of relevant con-

131. See, e.g., United States v. Hicks, 948 F.2d 877, 879-82 (4th Cir. 1991) (2.1 kilograms of cocaine enhanced to 9.8 kilograms as a result of $\$ 279,000$ found in defendant's home); United States v. Perdomo, 927 F.2d 111, 112-15 (2d Cir. 1991) (371 grams of cocaine enhanced to over two kilograms because of telephone conversation defendant had months earlier); United States v. Colon, 905 F.2d 580, 582-84 (2d Cir. 1990) (12 grams of heroin enhanced to 500 grams because defendant admitted ongoimg sales to probation officer).

132. 889 F.2d 1531 (6th Cir. 1989).

133. Id. at 1532-33.

134. See 21 U.S.C. $\S 841(b)(1)(B)$ (1988 \& Supp. III 1991).

135. See Guidelines MANUAL, supra note $64, \S \S 2 \mathrm{D} 1.1,5 \mathrm{~A}$.

136. Silverman, 889 F.2d at 1533-35.

137. The Sixth Circuit remanded the case to determine if the sentence violated the spirit and intent of the defendant's plea agreement. Id. at 1539. On remand, the district court held that the sentence did not contravene the plea agreement. United States v. Silverman, 730 F. Supp. 1418, 1422 (S.D. Ohio 1990), aff'd en banc, 976 F.2d 1502 (6th Cir. 1992). In a second appeal of the sentence, Silverman argued that his Sixth Amendment right to confront the witnesses against him was violated when the district court calculated the 87 -month sentence based on the hearsay statements of the government's confidential informer. The Sixth Circuit agreed and vacated the sentence, holding that Silverman was entitled to cross-examine the informant. United States v. Silverman, 945 F.2d 1337 (6th Cir. 1991), vacated en banc, 976 F.2d 1502 (6th Cir. 1992). However, three months later a rehearing en banc was granted and the decision vacating the sentence was itself vaeated. United States v. Silverman, 976 F.2d 1502 (6th Cir. 1992) (en banc).

138. This is probably an incorrect assumption in the actual Silverman case since there is no indication in the court's opimion that the one kilogram of cocaine was recovered. 
duct findings at the time of sentencing limits the ability of prosecutors to use the threat of additional charges that trigger inandatory punishment as leverage in plea bargaining. ${ }^{139}$

A pohicy statement of the guidelines, $\S 6 \mathrm{~B} 1.2(\mathrm{a})$, makes it difficult for prosecutors to use charge reductions to circumvent enhanceinents for relevant conduct. This provision instructs courts to accept plea agreements that include the dismissal of charges or promises not to pursue potential charges only "if the court determines, for reasons stated on the record, that the remaining charges adequately reflect the seriousness of the [defendant's] actual offense behavior." 140 In the absence of such a provision, parties could easily use charge reductions to evade mandatory minimum punishments because federal courts are not permitted to inpose sentences that exceed the statutory maximun for each offense for which a defendant is convicted. ${ }^{141}$

In many drug trafficking cases the prosecutor may be willing to dismiss charges carrying mandatory minimum enhancements if the defendant pleads guilty to simple possession of a controlled substance. This offense has a maximum penalty of one year in prison for a first offense. ${ }^{142}$ Or, if the facts of the case permit, the defendant may plead guilty to a "phone count," which is using a commumication facility to facilitate a drug transaction. This offense carries a maximuin punishment of four years. ${ }^{143}$ If the court accepts such a plea agreement, it cannot impose a longer sentence than the statutory maximuin for the offense of conviction, despite finding a sufficient amount of drugs to trigger a mandatory minimum sentence. Section 6B1.2(a) requires the court to reject the agreenrent if it finds that the phone count or simple possession charge does not adequately reflect the seriousness of the defendant's behavior. ${ }^{144}$

A third guidelines provision, $\$ 6 \mathrm{~B} 1.4(\mathrm{a})$, is a pohicy statement concerning plea agreements that include fact stipulations relevant to sentencing. It prohibits the parties from including "misleading facts" in such

139. Although prosecutorial plea bargaining power is reduced, it is not eliminated. See infra text accompanying notes 164-76.

140. Guidelines MANUAL, supra note $64, \S 6 \mathrm{~B} 1.2(\mathrm{a})$. This section implenients the congressional directive that judges should "examine plea agreenents to make certain that prosecutors have not used plea bargaining to undermime the sentencing guidelines." $S$. REP. No. 225, 98th Cong., 1st Sess. 63 (1983), reprinted in 1984 U.S.C.C.A.N. 3182, 3246.

141. The guidelines provide that when relevant conduct enhancements result in a sentencing range with a ninimun sentence higher than the statutorily authorized maxinum sentence for the offense of conviction, the court must sentence the defendant to the statutory maximum for the offense of conviction. GU1DELINES MANUAL, supra note 64, § SG1.1(a).

142. 21 U.S.C. $\$ 844$ (a) (Supp. III 1991).

143. 21 U.S.C. $\$ 843($ b), (c) (1988).

144. See GuIDELINES MANUAL, supra note $64, \S 6 \mathrm{~B} 1.2$ (setting standards for judges' acceptance of plea agreements). The key word in $\S 6 \mathrm{~B} 1.2$ is "adequately." Whenevcr trial courts are inclined to go along with plea bargains that include substantial charge reductions, they will find that reduced charges "adequately" reflect the seriousness of defendants' actual criminal behavior. See infra text accompanying note 260 . 
stipulations and requires them to set forth the circumstances of the defendant's "actual offense conduct and offender characteristics."145 The guideline seeks to prevent judicial findings of relevant conduct that are based on misleading or inaccurate stipulations. ${ }^{146}$ Otherwise, an erroneous determination of relevant conduct could hamper the imposition of mandatory minimum sentences. Section 6B1.4(a) thus seeks to ensure that all defendants factually eligible for mandatory minimum sentences receive them. ${ }^{147}$

\section{Coordination of Sentencing Guidelines with Mandatory Minimum Sentences}

Apart from the guidelines relating to drug trafficking offenses, the Sentencing Commission sought to assure that in each case the pumshment is proportional to the defendant's offense. The Commission accomphished this by estabhishing a contmuum of graduated increases and decreases in sentence severity for a wide variety of aggravating and mitigating circumstances. ${ }^{148}$ In contrast, each mandatory minimum sentence statute isolates a simgle aggravating circumstance and requires a disproportionate morease in pumshment whenever the circumstance is present. $^{149}$

This presented a dilemma for the Commission in setting the sen-

145. GUIDELINES MANUAL, supra note 64, § 6B1.4(a).

146. For example, the parties might stipulate to a weight of drugs that is far less than that actually possessed or sold by the defendant. Such stipulations could be used to circumvent a mandatory minimum sentence.

147. For a discussion of the effectiveness of these provisions, see infra Section III.B. The limitations in preventing plea negotiations from determining sentences stem from two problems. First, the court's access to relevant sentencing information, independent of the facts supplied by counsel, is severely limited. Second, even when the court learns of relevant conduct not reflected in a plea agreement, it may have its own reasons for going along with the agreement and declining to enforce harsh statutory punishments.

148. For example, the base offense level of the crime of robbery is 20. GuIDELINES MANUAL, supra note $64, \S 2 \mathrm{B3} .1$. The offense level increases by 2 if the property of a financial institution or post office was taken. Id. The offense level increases as follows: by 7 if a firearm was discharged in the robbery; by 6 if a firearm was otherwise used; by 5 if a firearm was brandished, displayed, or possessed; by 4 if a dangerous weapon was otherwise used; by 3 if a dangerous weapon was brandished, displayed, or possessed; and by 2 if an express threat of death was made. Id. If the robbery victim sustained bodily injury, the offense level is increased aecording to the seriousness of the injury. Id. If any person was abducted to facilitate the commission of the robbery or escape, the offense level increases by 4 . Id. If any person was physically restrained to facilitate the commission of the robbery or escape, the offense level increases by 2. Id. If a flrearm, destructive device, or controlled substance was taken in a robbery, the offense level increases by 1 . Id. The offense level also increases in proportion to the value of the loss. Id. Similarly, there are proportional increases in the sentencing range corresponding to the extent of the defendant's criminal history. Id. $\S 4 A 1.1$.

Mitigating circumstances serve to decrease the offense level. If the defendant was a "minimal" participant in the crime, the offense level decreases by 4 ; if the defendant was a "minor" participant, the offense level decreases by 2. Id. §3B1.2. If the defendant demonstrates an acceptance of personal responsibility for the offense, the offense level decreases by 2 . Id. §3E1.1.

149. See supra text accompanying notes 33-36. 
tence ranges for drug trafficking offenses. On the one hand, it could coordinate the drug trafficking guidelines with the mandatory minimum sentence statutes, thereby sacrificing individualized determinations of proportionality. On the other, it could draft guidelines that increase penalties for drug amounts in proportion to other aggravating circumstances, thereby creating an inconsistency with the mandatory minimum sentence laws. The Commission took the former approach.

For example, the Drug Quantity Table of $\S 2 \mathrm{D} 1.1(\mathrm{c})$ establishes gradations that correspond to inandatory sentence provisions of the AntiDrug Abuse Act of 1986. ${ }^{150}$ The Act requires a minimum of ten years in prison for distributimg, or possessing with intent to distribute, at least five kilograms of cocaine. ${ }^{151}$ The guidelines reflect this minimum sentence; they set the sentencing range at 121 to 151 months for possessing or distributing at least five but not more thian fifteen kilograms of cocaine. ${ }^{152}$ Moreover, altlough the Act does not require the guidelines to do so, the guidelines provide a graduated scale of pumshment for both greater and lesser weights of cocaine to make sentences proportionate. The pumishment for distributing between fifteen and fifty kilograms of cocaine is 151 to 188 months, and the punishment for distributing between 3.5 and 5.0 kilograins is 97 to 121 months. ${ }^{153}$ By using the mandatory minimum statutory provisions as a starting point and coordinating all penalties with the statutory provisions, the Sentencing Commission created severe punishments for all federal drug distribution offenses, even those below statutory threshold amounts.

In at least one instance, coordinating the guidelines for drug offenses with statutory inandatory minimum pumishment provisions results in a bizarre disparity in punishment. The guidelines sentencing range is two to eiglit inontlis for a first conviction of possessing 5.00 grams of crack cocaine. ${ }^{154}$ However, a first conviction of possessing 5.01 grams of crack cocaine carries a sentencing range of sixty-three to seventy-eight montlis. ${ }^{155}$ This enormous difference results froin the gap between the five-year mandatory minimum sentence for simple possession of inore thian five granis of crack-established by Congress as part of the Omnibus Anti-Drug Abuse Act of $1988^{156}$-and the maximum statutory

150. 21 U.S.C. $\$ 841$ (b)(1) (1988 \& Supp. III 1991) (offenses and penalties under the Anti-Drug Abuse Act of 1986).

151. Id. $\S 841(\mathrm{~b})(1)(\mathrm{A})$ (10-year minimum and life maximum sentence for manufacturing, distributing, or possessing with intent to distribute five kilograms or more of mixture or substance containing detectable amount of cocaine).

152. See GuIDELINES MANUAL, supra note 64, §§ 2D1.1, 5A.

153. See id. $\S$ 2D1.1(c)(5), (c)(7), 5A.

154. See id. §§ 2D2.1(a)(1), 5A.

155. See id. $\S \S 2 \mathrm{D} 1.1(\mathrm{c})(9), 2 \mathrm{D} 2.1(\mathrm{~b})(1), 5 \mathrm{~A}$.

156. Pub. L. No. $100-690, \S 6371,102$ Stat. 4181,4370 (codified as amended at 21 U.S.C. § 844(a) (Supp. III 1991)). 
punishment for simple possession of five grams or less of crack. ${ }^{157}$ The mandatory minimuni sentence statute thus compromises the proportionality of the guideline sentencing structure.

The Sentencing Commission's pohicy regarding 18 U.S.C. § 924(c) contrasts with its treatment of drug trafficking penalties. The Commission excluded the severe mandatory minimum enhanceinents of $\S 924$ (c) from the guidelines' grading structure. Section 924(c) requires a minimum consecutive sentence of five years for a first conviction of using or possessing a firearm while committing any crime of violence or drug trafficking. ${ }^{158}$ A second conviction carries a minimum consecutive sentence of twenty years. ${ }^{159}$ Several guidelines include less substantial enhancements for the possession or use of firearms. ${ }^{160}$ Pursuant to guideline $\S 1 \mathrm{~B} 1.3$, these lesser enhancements apply when the defendant has not been convicted of violating 18 U.S.C. $\S 924(c) .{ }^{161}$

When a defendant is convicted of violating $\S 924(c)$, guideline $\S 2 \mathrm{~K} 2$.4(a) instructs that the guideline enhancement for firearm possession is superseded and the court must impose the consecutive sentence required by the statute. ${ }^{162}$ This choice between sentencing alternatives enables prosecutors to use $\S 924(\mathrm{c})$ as a powerful bargaining chip to convince defendants to plead guilty. ${ }^{163}$ When this occurs, defendants are

157. See 21 U.S.C. § 844(a) (Supp. III 1991).

158. 18 U.S.C. $\$ 924(c)$ (1) (Supp. III 1991).

159. Id.

160. For example, guideline $\S 2 B 3.1(b)(2)$ sets forth the enhancements for the presence or use of a firearm in a robbery. Before it was amended in 1991, § 2B3.1(b)(2)(c) provided that if the offender possessed or displayed a dangerous weapon, including a firearm, the offense level increased by three. U.S. Sentencing Comm'n, Federal Sentencing Guidelines Manual § 2B3.1(b)(2)(c) (1990). Accordingly, the sentencing range for a first offender convicted of bank robbery increased from a range of 33 to 41 months to one of 46 to 57 months-an increase of 13 to 16 months-if he possessed a gun. See Guidelines Manual, supra note $64, \S 5$ A. This increase was far less than the mandatory five-year enhancement under 18 U.S.C. \$ 924(c). In 1991, § 2B3.1(b)(2)(c) was amended, increasing the offense level by five if a firearm was displayed or possessed in the commission of a robbery. GUIDELINES MANUAL, supra note $64, \S 2 \mathrm{B3} .1(\mathrm{~b})(2)$. The sentence range for a first offender convicted of bank robbery can now be increased from a range of 33 to 41 months to one of 57 to 71 months-an increase of 24 to 30 inonths-for possessing a firearm in the commission of the offense. Id. § 5A. This is still substantially less than the five-year enhaneenent under the statute.

161. GUIDELINES MANUAL, supra note $64, \S 1 \mathrm{~B} 1.3$ (establishing allowable factors in setting guideline range).

162. Id. $\S 2 \mathrm{~K} 2.4(\mathrm{a})$.

163. A federal judge accused the United States Attorney for the Eastern District of New York of having a policy of clarging under $\$$ 924(c) merely as a bargaining tactic. Memorandum of Sentencing Hearing \& Report of Statement of Reasons, United States v. Stanley, No. 88-CR-499(S2) (E.D.N.Y. July 19, 1990) (discussing low such policies created unwarranted sentencing disparities between defendants who chose to go to trial and those who pleaded guilty), reprinted in part in Tony Garoppolo, Confusion and Distortion in the Federal Sentencing Process, 27 CRIM. L. BuLL. 3, 16-17 (1991), aff'd in part and vacated in part, 928 F.2d 575 (2d Cir.), cert. denied, 112 S. Ct. 141 (1991). The judge also noted that probation officers and Legal Aid Society lawyers had advised the court that $\S 924(\mathrm{c})$ is "commonly" used by the governnent as a bargaining chip. Id. at 17. On appeal, the United States Attorney disputed the trial court's findings regarding the 
charged with $\S 924(c)$ in addition to their underlying offense and are subsequently offered the inore inodest guideline enhanceinent if they plead guilty.

\section{Federal Mandatory Punishment Statutes and Trial Rates}

Conventional wisdom regarding the guidelines' impact on the criminal trial rate holds that the guidelines have caused inore cases to go to trial since their implementation because their conduct-based sentencing structure takes away many of the incentives for plea bargaining. ${ }^{164}$ Many district judges have expressed the belief that the guidelines produce fewer plea bargains than existed under prior practice. ${ }^{165}$ Soine observers have predicted also that inore defendants will opt to go to trial as the plea bargaining dismcentives of the guidelines becoine better known. ${ }^{166}$

However, a close exannination of U.S. district court trial data indicates that these assumptions are wrong. Table 2 shows that during the five-year period preceding Noveinber 1987, when Congress authorized the guidelines to go into effect, $13.3 \%$ of criminal prosecutions im federal courts went to trial. In 1991, however, the federal criminal trial rate actually had declined shightly, to $12.9 \% .^{167}$ Other studies of trial rates under the guidelines have been consistent with these findings. One such comparison found that the overall trial rate did not change significantly; although the trial rate for offenses involving weapons and drugs

prosecutorial use of $\S 924(\mathrm{c})$ as a bargaining chip. United States v. Stanley, 928 F.2d 575, 579 n.1 (2d Cir.), cert. denied, 112 S. Ct. 141 (1991).

164. Attributing changes in federal court criminal trial rates to particular causes can be hazardous because several developnients, in addition to the enactment of the principal inandatory mininum sentence statutes and the implententation of the guidelines, have influenced federal practice in recent years. For example, prosecutorial plea bargaining policies have changed on nore than one occasion during the past several years. The Justice Department issued its "Redbook," setting forth new policies for Assistant United States Attorneys with regard to charging and plea bargaining on Noveniber 1, 1987, the day the guidelines were to go into effect. U.S. Dep't of Justice, Prosecutor's Handbook on Sentencing Guidelines (1987) (on fle with the California Law Review). This policy statenient was modified by a inemorandum to U.S. Attorneys from Attorney General Thornburgh shortly after the Suprenie Court decided Mistretta v. United States, 488 U.S. 361 (1989). Meniorandum from Richard Thornburgh, U.S. Attorney General, to Federal Prosecutors (Mar. 13, 1989) (on file with the California Law Review).

165. At the direction of Congress, a committce appointed by the Chief Justice to study congestion, delay, and expense in the federal courts conducted a survey of federal district judges concerning their workload. When questioned about the sentencing guidelines, $49.7 \%$ of the judges stated the opinion that the percentage of guilty pleas had decreased under the guidelines, $5.4 \%$ believed that the percentage had increased, and $44.9 \%$ beheved that the percentage remamed unchanged. See Summary of Responses to the Survey of District Court Judges, in 2 FEDERAL Courts Study Comm., Working Papers and SubCommittee Reports (1990).

166. E.g., Theresa W. Karle \& Thomas Sager, Are the Federal Sentencing Guidelines Meeting Congressional Goals? An Empirical and Case Law Analysis, 40 EMORY L. J. 393, 406 (1991) (speculating on the effects of the guidelines on plea bargaining in the federal system).

167. This decrease is not statistically siguificant at the 0.05 level. $Z=1.538, p<0.10$. 
increased, the trial rate for certain other offenses decreased. ${ }^{168}$

TABLE 2

Disposition of Defendants In U.S. District CourtS

BEFORE AND AFTER SENTENCING GUIDELINES ${ }^{169}$

\begin{tabular}{|c|c|c|c|c|}
\hline \multirow[b]{2}{*}{ Year } & \multirow[b]{2}{*}{$\begin{array}{c}\text { Total } \\
\text { Defendants }\end{array}$} & \multicolumn{3}{|c|}{ Percentage of Cases Resulting in: } \\
\hline & & Dismissal & Trial & $\begin{array}{c}\text { Plea of Guilty } \\
\text { or Nolo Contendere }\end{array}$ \\
\hline $7 / 82-6 / 83$ & 43,329 & 15.2 & 14.4 & 70.4 \\
\hline $7 / 83-6 / 84$ & 44,501 & 15.8 & 13.5 & 70.7 \\
\hline $7 / 84-6 / 85$ & 47,360 & 15.8 & 12.8 & 71.4 \\
\hline $7 / 85-6 / 86$ & 50,040 & 15.8 & 13.4 & 70.8 \\
\hline$\underline{7 / 86-6 / 87}$ & 54,168 & 16.2 & 12.8 & 71.0 \\
\hline 7/82-6/87 & 239,398 & 15.8 & 13.3 & 70.9 \\
\hline $1 / 91-12 / 91$ & 56,829 & 14.5 & 12.9 & 72.6 \\
\hline
\end{tabular}

Certain features of the guidelines counteract the expected effects of conduct-based sentencing ${ }^{170}$ and may lead to lower trial rates. First, a defendant who pleads guilty can expect a guideline sentencing discount of twenty to thirty-five percent for "acceptance of responsibility." 171 Second, a defendant who goes to trial is less likely to receive a sentence at the lower end of the sentencing range for the offense of conviction and is more likely to receive a sentence nearer to the maximum of the range. ${ }^{172}$ Third, a defendant who goes to trial and testifies in his own defense may risk an upward sentencing adjustment under the guidelines for obstruc-

168. Terence Dunworth \& Charles D. Weisselberg, Felony Cases and the Federal Courts: The Guidelines Experience, 66 S. CAL. L. REV. 99 (1992). Another study compared plea bargaining practices in district courts in Louisiana, Mississippi, and Texas before and after the implementation of the guidelines, with regard to 13 offense categories. The authors reported a decrease in plea bargaining in certain categories (including distribution of cocaine) but no statistically significant change in the overall guilty plea rate for all 13 offenses. Karle \& Sager, supra note 166 , at $402-04$. A study reporting data from four districts in the Eighth Circuit in 1989 found an overall decrease in the percentage of defendants pleading guilty in both drug and nondrug cases. Heaney, supra note 3 , at $175-76$.

169. Data come from the 1991 survey of courts by the Administrative Office of the U.S. Courts, Statistical Division (data on file with the California Law Review).

170. See supra Section II.C.1.a.

171. Guidehines $\S 3 E 1.1$ provides that if a defendant "clearly demonstrates a recognition and affirmative acceptance of personal responsibility for his criminal conduct," the court should "reduce the offense level by 2 levels." GuIDELINEs MANuAL, supra note 64, §3E1.1(a). This two-level discount corresponds to a $25 \%$ to $35 \%$ reduction in sentence, depending on the seriousness of the offense of conviction. See Schulhofer \& Nagel, supra note 3, at 243-45.

172. See Heaney, supra note 3 , at $\mathbf{1 8 0 - 8 1}$ (study in four federal districts showing that defendants who pleaded guilty were inore likely to be sentenced in lower the quartile of the sentencing range than defendants who went to trial; defendants who went to trial were more likely to be sentenced in the upper quartile of the sentencing range than defendants who pleaded guilty). 
tion of justice. ${ }^{173}$ Fourth, the guidelines authorize a downward departure from an otherwise apphicable sentencing range when the prosecutor avers that the defendant has provided substantial assistance to investigating authorities. ${ }^{174}$ Many prosecutors offer this opportunity as an incentive for defendants to plead guilty. ${ }^{175}$ Finally, despite exphicit guidelines to the contrary, district courts continue to accept plea bargains that reduce charges to offenses with lower maximuni sentences, thus limitimg guideline enhanceinents for relevant conduct. ${ }^{176}$

Although the criminal trial rate in general may have declined shightly under the guidelines, it has increased measurably in drug cases. Table 3 shows that the trial rate for all offenses imvolving controlled substances or drugs other than inarijuana was $16.9 \%$ during the last preguidelines fiscal year, while the trial rate for these offenses in 1991 was $19.7 \% .{ }^{177}$

TABLE 3

Trial Rates of Defendants in Drug Cases in U.S. District COURTS BEFORE AND AFTER GUIDELINES ${ }^{178}$

\begin{tabular}{cccccc}
$\begin{array}{c}\text { Year } \\
\text { ending }\end{array}$ & $\begin{array}{c}\text { Number of } \\
\text { Defendants } \\
\text { im Drug } \\
\text { Cases }\end{array}$ & $\begin{array}{c}\text { Nuniber of } \\
\text { Defendants } \\
\text { Going to } \\
\text { Trial }\end{array}$ & $\begin{array}{c}\text { Percentage } \\
\text { Going to } \\
\text { Trial }\end{array}$ & $\begin{array}{c}\text { Number } \\
\text { Acquitted } \\
\text { at Trial }\end{array}$ & $\begin{array}{c}\text { Percentage } \\
\text { Acquitted } \\
\text { at Trial }\end{array}$ \\
\hline $6 / 30 / 87$ & 10,726 & 1,808 & 16.9 & 258 & 14.3 \\
$12 / 31 / 91$ & 14,197 & 2,795 & 19.7 & 374 & 13.4
\end{tabular}

This significant increase in the percentage of drug prosecutions proceeding to trial suggests that federal prosecutors are not using mandatory sentence statutes for plea bargaining leverage as frequently as their counterparts in states that rely more extensively on charge-based sentenc-

173. Guideline $\S 3$ C1.1 provides a two-level increase in offense level for "[o]bstructing or [i]mpeding the [a]dministration of [i]ustice." GuIDELINES MANUAL, supra note $64, \S 3 \mathrm{Cl}$.1. The application notes to this section include as examples "committing, suborning, or atteinpting to suborn perjury," as well as "providing inaterially false information to a judge or inagistrate." Id. $\S 3$ C1.1 application notes $3(\mathrm{~b})$, (f). The Supreme Court recently affirmed a trial court's application of $\S 3 \mathrm{Cl} .1$ to increase a defendant's sentence when the judge believed the defendant had testified untruthfully. United States v. Dunnigan, 113 S. Ct. 1111 (1993).

174. GUIDELINES MANUAL, supra note $64, \S 5 \mathrm{~K} 1.1$.

175. See Ilene H. Nagel \& Stephen J. Schulhofer, A Tale of Three Cities: An Empirical Study of Charging and Bargaining Practices Under the Federal Sentencing Guidelines, 66 S. CAL. L. REv. 501 (1992) (prosecutors acknowledge that sometimes they offer substantial assistance sentencing departures to induce pleas even when facts do not show much cooperation by defendant).

176. See infra Section III.B.

177. This increase is statistically significant. $Z=2.3916, p<0.01$.

178. Data coine from the 1991 survey of courts by the Administrative Office of the U.S. Courts, Statistical Division (data on file with the California Law Review). 
ing. ${ }^{179}$ A combination of three factors can explain this circumstance: (1) the severity of mandatory statutory penalties for drug offenses, (2) the Sentencing Commission's decision to base sentence ranges for drug offenses on the mandatory sentence statutes, and (3) the actual conductbased sentencing scheme of the guidelines.

The great majority of offenders who are eligible for and receive federal mandatory minimum sentences are defendants in federal drug prosecutions. ${ }^{180}$ The guidelines for drug trafficking offenses reflect the severity of the penalties in the Anti-Drug Abuse Act of $1986 ;{ }^{181}$ guidelines punishment enhancements based on the weight of substances in drug transactions are disproportionate to the penalty adjustments for all other aggravating and mitigating circumstances. ${ }^{182}$ The guidehines' conductbased sentencing provisions require courts to impose severe sanctions for drug offenses even in cases $m$ which the defendant has not been convicted of trafficking the drugs in question. ${ }^{183}$ Thus, unless defendants qualify for sentencing departures for substantial assistance or prosecutors offer charge reductions to lesser offenses without mandatory penalties, drug trafficking defendants have hittle reason to plead guilty. The guidelines do provide a plea bargaining incentive by mcluding a sentencing discount for "acceptance of responsibility." 184 However, this reduction is modest even when the defendant's sentence is at the lowest end of the guideline range. A small reduction in an otherwise long mandatory sentence offers little incentive to plead guilty.

\section{Procedural Effects of Federal Mandatory Punishment Statutes}

While the federal trial rate of drug prosecutions suggests that federal prosecutors have not used mandatory minimum sentences to induce plea bargaining as frequently as have state prosecutors, the conduct-based sentencing scheme of the federal guidelines impacts the fairness of the procedures used in federal criminal cases in two other important ways. First, the guidehines' emphasis on conduct-based sentencing leads to a less reliable factfinding process than that occurring under charge-based

179. See supra text accompanying notes 76-105 (discussion of Arizona's experience).

180. Of the 6685 defendants convicted under mandatory minimum provisions, 5752 defendants-86\%-were convicted of controlled substance offenses between October 1, 1989, and September 30, 1990. U.S. SENTENCING COMM'N, supra note 12, at 51. Federal drug prosecutions generally involve allegations of drug trafficking-including importation, possession with intent to distribute, distribution of drugs within the United States, and use of a communication facility in the commission of a drug offense. Id. at 51 n.4.

181. The Anti-Drug Abuse Act of 1986, Pub. L. No. 99-570, 100 Stat. 3207, set mandatory minimum sentences for drug trafficking offenses according to the weight of mixtures or substances containing controlled substances. See 21 U.S.C. § 841(b)(1) (1988 \& Supp. III 1991).

182. For a discussion of these guidelines, see supra text accompanying notes 148-57.

183. For a discussion of the guidelines' conduct-based sentencing provisions, see supra text accompanying notes 121-31.

184. See supra note 171 and accompanying text. 
sentencing. Second, application of conduct-based sentencing to drug prosecutions may weaken the Fourtl Amendment exclusionary rule in federal courts.

\section{a. Factfinding}

An important feature of mandatory sentence enhancement laws is the extent to whicl substantial deprivations of liberty turn on the disputed existence of aggravating circumstances. A conduct-based sentencing system delays the resolution of these factual issues from the trial stage of a criminal prosecution to the sentencimg stage, calling into question the fairness and accuracy of the factfinding process. For example, a defendant who has been cliarged witl possessing a small amount of crack cocaine for personal use may not contest his possession of the drug, but may deny the prosecutor's claim tliat it came from a supply of more than five grams. Sliould the court accept, at the guidelines sentencing liearing, the government's contention concerning the source of the drug, a sixmonth sentence for possession becomes a six-year sentence. ${ }^{185}$ Moreover, the defendant does not liave the right to a jury at the sentencing learing, ${ }^{186}$ hearsay is admissible, ${ }^{187}$ and the prosecution's burden of persuasion is reduced from proof beyond a reasonable doubt to a preponderance of the evidence. ${ }^{188}$

185. The guideline sentencing range for a first offense of possession of less than five grams of crack cocaine is 2 to 8 inonths imprisonment. See GuIDELINES MANUAL, supra note 64, $\S \S 2 \mathrm{D} 2.1(\mathrm{a})(1), 5 \mathrm{~A}$. If the crack caine from a supply that exceeded five grams, the range is 63 to 78 months. See id. §§ 2D2.1(b)(1), 2D1.1(c)(9), SA.

186. Spaziano v. Florida, 468 U.S. 447,459 (1984) (holding that the Sixth Amendinent does not guarantee the right to jury determination of the senteuce).

187. See Williams v. New York, 337 U.S. 241, 252 (1949) (holding that use of information obtained outside the courtrooin froin people whom defendant cannot confront or cross-examine at the sentencing stage does not violate due process). A policy statement included in the federal sentencing guidelines provides that a court may determine the facts related to a sentencing decision by considering relevant information "without regard to its adinissibility under the rules of evidenee applicable at trial, provided that the information has sufficient indicia of reliability to support its probable accuracy." GUIDELINES MANUAL, supra note 64, §6A1.3(a). One study of guideline sentencing practices in four districts noted that sometimes the only proof of facts requiring sentence enhanccinents is a hearsay statement in the presenteuce report, taken from a prosecutor, or investigator's case file. Heaney, supra note 3, at 209-10.

188. In McMillan v. Pennsylvania, 477 U.S. 79 (1986), the Supreme Court upheld a Pennsylvania mandatory sentence statute that required a five-year minimuin sentence if the sentencing court found, by a preponderance of the evidence, that the defendant possessed a firearm during the cominission of the offeuse. The Court concluded that since the firearm possession allegation was a seutencing consideration and not an eleinent of the underlying offense, it need not be proved beyond a reasonable doubt. Id. at $85-86$. The Court went on to hold that proof by a preponderance of the evideuce in the sentencing context was sufficient to satisfy the Due Process Clause. Id. at 91-93. Federal courts have followed McMillan's reasoning in approving a preponderance of the evidence standard for determinations of relevant conduct uuder the federal sentencing guidelines. See United States v. Silverman, 889 F.2d 1531, 1535 (6th Cir. 1989); United States v. Urrego-Linares, 879 F.2d 1234, 1237-38 (4th Cir.), cert. denied, 493 U.S. 943 (1989); United States v. Wright, 873 F.2d 437, 441 (1st Cir. 1989); see also United States v. Ebbole, 917 F.2d 1495, 1499-500 (7th Cir. 1990) (defendant's due process rights were not violated when the guidelines 
This delayed factfinding also results in a critically important role for a probation officer's presentence investigation report. Although trial judges have traditionally rehed and continue to rely heavily on probation officers' sentencing recommendations, ${ }^{189}$ a probation officer engaged in a presentence investigation may not have the time, resources, or expertise to conduct an exhaustive inquiry. Often, she must rely on the reports of the law enforcenent officers who have conducted criminal investigations in the case. ${ }^{190}$ Those reports may be filled with hearsay information relating to criminal activity and speculation concerning suspects' roles in that activity. In a drug trafficking case, judicial findings of relevant conduct can derive from presentence reporting of extensive drug activity. Such relevant conduct findings can then translate directly into a substantial sentence enhancement, even though the defendant is arrested with only a sinall quantity of drugs in her possession and is convicted of possessing only that sinall amount. ${ }^{191}$

United States v. Perdomo ${ }^{192}$ graphically illustrates this. Perdomo pled guilty to conspiracy to distribute cocaine based on his July 1988 arrest in Vermont for possessing a package containing 371 grams of cocaine that had been shipped froin Miaini. ${ }^{193}$ According to the presentence report, federal agents had investigated Perdoino several months earlier for participating in a larger conspiracy involving the transportation of substantial quantities of cocaine froin Miami to

required the sentencing judge to increase the sentence because of uncharged conduct proved by a preponderance of the evidence); cf. United States v. Lee, 818 F.2d 1052, 1057 (2d Cir.) (preponderance of the evidence standard approved in pre-guidelines sentencing, citing McMillan), cert. denied, 484 U.S. 956 (1987). For a discussion of the preponderance of the evidence standard under the federal guidelines, see Steven M. Salky \& Blair G. Brown, The Preponderance of Evidence Standard at Sentencing, 29 AM. CRIM. L. REV. 907 (1992).

189. A recent study of guideline sentencing practices in four federal districts found that the sentencing court followed the probation officer's calculation of the appropriate sentencing range in $90 \%$ percent of all cases. See Heaney, supra note 3, at 169 n.22. For a coinparison of the role of federal probation officers preparing presentence reports before and after the guidelines went into effect, see Jerry D. Denzlinger \& David E. Miller, The Federal Probation Officer: Life Before and After Guideline Sentencing, Fed. Probation, Dee. 1991, at 49-52.

190. Heaney's study of sentencing practices in the Eighth Circuit found that probation officers rely "almost exclusively on ... government-provided information." Heaney, supra note 3, at 173. William W. Wilkins, chairman of the U.S. Sentencing Commission, commented on Heaney's finding by noting that probation officers have always relied priniarily on information in the government's files, both before and after the guidelines. See Wilkins, supra note 117, at 802. Another cominentator has opined that Heaney's finding of excessive judicial reliance on probation officers' reports is "exaggerated." See Schulhofer, supra note 3, at 843.

191. See, e.g., United States v. Silverman, 889 F.2d 1531, 1534-35, 1538-39 (6th Cir. 1989) (relevant conduct finding of sale of one kilogram of cocaine increased defendant's sentence from between 21 and 27 months to 87 inonths).

192. 927 F.2d 111 (2d Cir. 1991).

193. The package actually contained 2.5 kilograms of white powder; of this, only 371 grams were pure cocaine. Id. at 113 . Since the 2.5 kilograms of white powder were a "mixture or substance containing a detectable amount" of cocaine, 21 U.S.C. § 841(b)(1)(B)(ii) (Supp. III 1991), it is not clear why the court counted only 371 grams in determining Perdouno's sentence. See 927 F.2d at 114 . 
Canada. ${ }^{194}$ DEA agents' reports indicated that they had overheard a March 1988 telephone conversation in which Perdoino agreed to dekiver two kilograms of cocame to a group of buyers in Montreal. ${ }^{195}$ Relying on this hearsay information, the district court calculated Perdono's sentence by adding two kilograms of cocaine to the 371 grams found in his possession. The court then adjusted the sentence again because the presentence report supported the conclusion that Perdoino was a manager or supervisor of criminal activity involving five or inore participants. ${ }^{196}$ As a result, Perdomo received a sentence of 168 inonths incarceration, instead of the 41-51-month range applicable to the 371 grams of cocaine lie possessed at the time of his arrest. ${ }^{197}$ Thus, his sentence was increased by approximately ten years based on the probation officer's liearsay account of teleplione conversations overheard months earher by DEA agents.

Presentence reports are also based on the probation officer's interview of the defendant. This sometimes leads to problems when inandatory enhancements are based on the sentencing court's findings concerning the totality of the defendant's offense beliavior. In United States v. Colon, ${ }^{198}$ for example, tlie defendant pled guilty to selling four grams of leroin in Manhattan's Hell's Kitclien and possessing an additional 4.1 grams when he was arrested. ${ }^{199}$ During his interview with the probation officer preparing the presentence report, Colon admitted to a $\$ 150$ a day liabit, stating that lie purcliased 100 glassine envelopes of heroin every few days, used soine himself, and sold the reinamder to support his liabit. ${ }^{200}$ From this confession, the trial court estimated tliat Colon liad sold 500 grams of lieroin over the two years before his arrest. Based on this estimate, the court sentenced him to fifteen years in prison. ${ }^{201}$ The Second Circuit lield that the defendant's confession to the probation officer could be used to determine the defendant's relevant conduct for sentencing. ${ }^{202}$

194. 927 F.2d at 113.

195. Id.

196. Id. The Second Circuit affirmed these aspects of the defendant's sentence. Id. at 115, 117 .

197. The guideline offense level for conspiracy to distribute 371 grams of cocaine is 22 . GuideLiNES MANUAL, supra note 64, §2D1.1(c)(11). The sentence range for a first offender at level 22 is 41 to 51 inonths. Id. $\S 5 A$ (Sentencing Table).

198. 905 F.2d 580 (2d Cir. 1990).

199. Id. at 582. Colon had sold the heroin within 1000 feet of a school, which doubled the applicable quantity from four to eight grams for sentencing purposes, under Guideline $\S 2 D 1.3(\mathrm{a})(2)(\mathrm{b})$. Id.; see GUIDELINES MANUAL, supra note $64, \S 2 \mathrm{D} 1.2$ (current codification of $\S 2 \mathrm{D} 1.3$ ). Together with the 4.1 grams in his possession, the base amount was approximately 12 grams. Colon, 905 F.2d at 582 .

200. Colon, 905 F.2d at 582 .

201. Id. at 583 .

202. Id. at 588. Without disturbing this finding, the Second Circuit remanded for resentencing because the trial judge had considered the earlier sales involving 500 grams as allowing him discretion to depart from the guidelines. The Second Circuit held that these earlier sales should have 
The Perdomo and Colon courts both imposed severe punishment based on factual allegations that had not undergone the rigors of the trial process. Cases like these exemplify the difficulties inherent in applying mandatory enhancements in a conduct-based sentencing system. First, potential for abuse exists when the principal sources of information for calculating the length of sentences im drug prosecutions are the investigative reports of law enforcement personnel. Nothing prevents government agents from preparing slanted reports, including information purportedly from umidentified "confidential informants," in order to influence sentencing decisions. Second, the use of defendants' confessions to probation officers as the basis for severe sentence enhancements contradicts criminal justice principles such as the corpus delicti rule and the notion that acceptance of responsibitity for criminal behavior sliould operate as a mitigating factor in punishment. ${ }^{203}$

\section{b. Fourth Amendment Considerations: Use of Unlawfully Obtained Evidence}

The interaction between mandatory minimum punishments and conduct-based sentencing has also severely undermined the value of the Fourtl Amendment exclusionary rule in federal drug prosecutions. Eacl of the circuits addressing the issue has ruled that in the determination of relevant conduct for sentencing purposes, trial courts may consider evidence seized in violation of the Fourtl Amendment. ${ }^{204}$

been considered as relevant conduct for determining the base level of offense, not as grounds for a departure. Id. at 586-88. Although the appellate court opined that the trial court's error had "no practical impact" on the outcome, it remanded anyway. Id. at 587. On remand, the trial court's determination was substantially the same, holding that Colon distributed 400 grams and sentencing him to 14 years in prison; on appeal, the sentence was affirmed. United States v. Colon, 961 F.2d 41, 43-44 (2d Cir. 1992).

203. The guidelines do provide a modest sentencing discount for acceptance of responsibility. See GuIDELINES MANUAL, supra note $64, \S 3 E 1.1$ (a) (downward adjustment of two levels froin base offense if defendant "clearly demonstrates a recognition and affirmative acceptance of personal responsibility for his crimmal conduct"). When the defendant in Colon honestly told his probation officer about the drug distribution activity that supported his habit, the resulting mandatory sentence enhancement dwarfed the downward adjustment for showing remorse.

204. See, e.g., United States v. McCrory, 930 F.2d 63, $67-69$ (D.C. Cir. 1991) (additional deterrent effect of applying the exclusionary rule in sentencing is outweighed by the detrimental effects of exclusion), cert. denied, 112 S. Ct. 885 (1992); United States v. Torres, 926 F.2d 321, 325 (3d Cir. 1991) (evidence suppressed at trial for a Fourth Amendment violation may be used to determine the base offense level under the guidelines). Pre-guidelines caselaw is similar. See United States v. Graves, 785 F.2d 870, 873 (10th Cir. 1986) (extending the exclusionary rule to sentencing proceedings would unduly complicate sentencing for minimal deterrent effect); United States v. Butler, 680 F.2d 1055, 1056 (5th Cir. 1982) (broad mquiry at sentencing may include consideration of evidence inadmissible at trial); United States v. Lee, 540 F.2d 1205, 1211 (4th Cir.) (extending the exclusionary rule to sentencing would have only minimal deterrent effect), cert. denied, 429 U.S. 894 (1976). But see Verdugo v. United States, 402 F.2d 599, 610-13 (9th Cir. 1968) (illegally seized evidence is not admissible for consideration by the judge in determining sentence), cert. denied, 402 U.S. 961 (1971). 
United States v. McCrory ${ }^{205}$ is illustrative. Ten minutes after the defendant sold less than a gram of crack cocaine to undercover agents, a group of police officers broke down the door to the defendant's apartment, rushed inside, arrested the defendant, and later searched the premises, finding about one and one-half kilograms of crack cocaine. ${ }^{206}$ Although McCrory was convicted of the initial sale, he was not prosecuted for possessing the large stash in his apartment after the U.S. Attorney stipulated, in response to the defendant's motion to suppress, that the evidence would not be used in the government's case-in-chief. ${ }^{207}$ The applicable guideline sentencing range for the sale was 27 to 33 months incarceration, but the trial court sentenced McCrory to 235 months in prison, counting the one and one-half kilograms as relevant conduct. ${ }^{208}$ The Court of Appeals for the District of Columbia Circuit affirmed, ${ }^{209}$ basing its reasoning on decisions of the United States Supreme Court in Williams v. New York ${ }^{210}$ and United States v. Calandra. ${ }^{211}$

In Williams, the Court rejected a due process challenge to a death sentence based in part on hearsay information and the inflammatory opinions of a probation officer. ${ }^{212}$ The trial court overruled a jury recomniendation of life imprisoninent for a defendant convicted of murder in the course of burglary, and imstead imposed a death sentence after considering a presentence report that stated that the defendant had committed thirty other uncharged burglaries, was a "menace to society," and had a "morbid sexuality."213 In upholding the sentence, the Court noted that New York had sound reasons for not requiring sentencing courts to follow the rules of evidence apphicable during criminal trials, since information of all kinds and from all sources was useful in tailoring punish-

205. 930 F.2d 63 (D.C. Cir. 1991), cert. denied, 112 S. Ct. 885 (1992).

206. Id. at 64-66.

207. Id. at 65 . However, the "government exphicitly stated that it would introduce all of the seized evidence at sentencing and, should [the defendant] 'open the door,' would seek to introduce the evidence at trial." Id.

208. Counting both the large amount of drugs and the weapons found in the apartinent, the court calculated the applicable sentencing range to be 235 to 293 months and imposed a sentence of 235 months. Id. The court noted that had McCrory been charged and convicted for possession of the additional cocaine and firearms recovered in the illegal search, his sentence would have ranged from 248 to 295 months, 2 to 13 inonths greater than the range he actually received. Id. at 66 \& n.1. Nonetheless, $\mathrm{McCrory}$ is a chilling deinonstration of how evidence seized unconstitutionally may operate to increase a defendant's sentence vastly when the offense is neither charged nor proven.

209. Id. at 69 .

210. 337 U.S. 241 (1949).

211. 414 U.S. 338 (1974).

212. 337 U.S. at 244 . The defendant argued in his due process claim that he had not been given fair notice of the charges the court relied on when imposing the death sentence and that he was denied an opportunity to confront his accusers. Id. at 245.

213. Id. at 244. The report indicated that Williams "had confessed to some [of the burglaries] and had been identified as the perpetrator of soine of the others." Id. 
ment to "fit the offender and not merely the crime."214 The more information the sentencing court had concerning the offender's life and characteristics, the better it could achieve the primary goals of punishinent: reformation and rehabilitation. ${ }^{215}$

Rehance on Williams to justify the use of unlawfully seized evidence in guidelines sentencing is misplaced. The Court decided Williams in 1949, during the era of indeterminate sentencing. At that time information concerning other crimes committed by the defendant was relevant to the sentencing decision not because the punishment was to be commensurate with the harm he had caused, but because his criminal activity reflected on his character and fitness for rehabilitation. ${ }^{216}$ Today, however, Congress has expressed its legislative judgment that rehabilitation of the offender is no longer a legitimate purpose of punishment under the guidelines. ${ }^{217}$ The guidelines prohibit courts from considering inany offender characteristics that were central to indeterminate sentencing, such as age, einployment status, and family relationships. ${ }^{218}$ Judges no longer have discretion to tailor an appropriate sentence to each case. Instead, current sentencing law requires them to follow mechanistic, inflexible sentencing formulae.

In contrast to Williams, United States v. Calandra offers support for the introduction of unlawfully seized evidence in guidelines sentencing hearings. Calandra exemplifies the post-Warren Court's determination to limit Fourth Amendment application to the prosecution's case-in-chief at trial. The Calandra Court held that a grand jury witness inay not refuse to answer questions on the ground that they are based on illegally seized evidence. ${ }^{219}$ Justice Powell's opmion for the Court balanced the costs of applying the exclusionary rule in grand jury proceedings against the benefits derived from excluding testimony based on unlawfully obtained evidence. ${ }^{220}$ Justice Powell concluded that permitting witnesses to invoke the exclusionary rule would result in substantial delay and disruption of grand jury proceedings, while the "incremental deterrent

214. Id. at 247.

215. Id. at $248-49$.

216. Justice Black's opinion for the Williams Court emphasized the rejection of retribution and the importance of reformation and rehabilitation as the principal purposes of sentencing in the mid20th century. Id. at 248 ("Retribution is no longer the dominant objective of the criminal law. Reformation and rehabilitation of offenders have become important goals of criminal jurisprudence.").

217. One provision of the Sentencing Reform Act of 1984 states: "The Commission shall insurc that the guidelines reflect the inappropriateness of imposing a sentence to a term of imprisonment for the purpose of rehabilitating the defendant or providing the defendant with needed educational or vocational training, medical care, or other correctional treatment." 28 U.S.C. $\$ 994(\mathrm{k})$ (1988).

218. See GuIDELINES MANUAL, supra note $64, \S \S 5 \mathrm{H} 1.1, .5-6$ (prohibiting courts from considering age, employment record, and fanily responsibilities as reasons to depart from narrow guidelines sentence ranges).

219. United States v. Calandra, 414 U.S. 338, 353-55 (1974).

220. Id. at 349-52. 
effect" of excluding evidence at the grand jury stage was "uncertain at best.".221

While excluding the fruits of illegally seized evidence from grand juries inay have hittle deterrent effect on police misconduct, excluding this evidence in the sentencing context may impact police behavior substantially. When police officers, as in $\mathrm{McCrory}$, liave already coinpleted a drug purchase and suspect that a larger amount is inside a residence, an exclusionary rule applied at sentencing may be the most important deterrent to a police search violative of the Fourth Amendinent. An illegal entry and searcli of the residence will not jeopardize the probable conviction for the completed drug sale, and a drug dealer is not likely to be a successful plaintiff im a civil action. Without an exclusionary rule apphed at sentencing, the court can consider anything uncovered during the illegal search when it determines relevant conduct. Evidence obtained in violation of federal constitutional guarantees can thus become relevant conduct and operate to increase the defendant's sentence significantly. Without an exclusionary rule at sentencing, Fourth Amendment protection is severely eroded.

On the other land, just as exclusion of illegally seized evidence can disrupt the grand jury's investigative function, the principal goals of federal guidelines sentencing are best served if the exclusionary rule does not apply at sentencing. Harm-based retribution is the principle of the guidelines; punishment is to be proportional to the liarm caused by the defendant's conduct. The Commission structured its sentencing rules on actual conduct to achieve this proportionality: regardless of the prosecutor's clioice of cliarges and the outcome of plea bargaining, the guidelines grade punishments by reference to the defendant's actual conduct. Given these retributive goals, the exclusion of relevant sentencing information about the defendant's conduct for reasons unrelated to the defendant's behavior-even constitutional violations-conflicts with the purposes of this liarm-based sentencing structure. As a result, courts lave lield that the Calandra balance weighs more heavily in favor of not applying the exclusionary rule. ${ }^{222}$ In light of the Commission's policy decisions and sentencing procedures, the Fourtl Amendment will have substantially diminished efficacy in future federal drug prosecutions.

III

MaNdatory Punishment and the Goals of Determinate SENTENCING

The mandatory sentence enhancement laws enacted during the past two decades liave underinined the goals of the conteinporaneous sentenc-

221. Id. at 351 .

222. See cases cited supra note 204. 
ing reform movement. The primcipal purpose of determinate sentencing has been to end the substantial and widespread disparities that existed when trial courts had broad, unguided discretion in imposing punishment. $^{223}$ Legislatures have tried to assure, as nuch as possible, that persons committing similar offenses receive similar punishments. ${ }^{224}$ The object of state and federal sentencing guidelines, ${ }^{225}$ presumptive sentences and limited sentencing ranges, ${ }^{226}$ prosecutorial plea bargaining guidelines, ${ }^{227}$ and appellate review of sentencing ${ }^{228}$ has been to eliminate unwarranted disparity in the punishment of offenders. Although soine critics claim that the reforms have failed in their mission, ${ }^{229}$ the worst of today's disparities derive more from mandatory punishment than fron sentencing guidelines or statutory presumptive sentences.

223. The foundation of the sentencing reform movement was a large and varied literature that emerged in the 1970s and early 1980 s and demonstrated the many disparities resulting from indeterminate sentencing schemes. See FAIR AND CERTAIN PUNISHMENT, supra note 28; DAvid Fogel, “. . . We ARE THE LIVINg PROOF . . .” THE JUSTICE MOdel For CORRECTIONS (1975); Marvin E. Frankel, Criminal SeNTENCES: LAW WIThout ORDER 103-24 (1973); Jessica Mitford, Kind and Usual Punishment: The Prison Business (1973); ANTHony Partridge

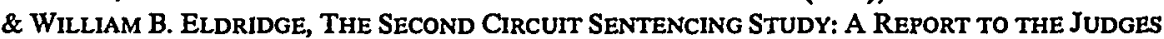
OF THE SECOND CIRCUIT (1974); ANDREW VON Hirsch, DOING JUSTICE: THE ChOICE OF Punishments 98-100 (1976); William Austin \& Thomas A. Williams, III, A Survey of Judges' Responses to Simulated Legal Cases. Research Note on Sentencing Disparity, 68 J. CRIM. L. \& Criminology 306 (1977); Shari S. Diamond \& Hans Zeisel, Sentencing Councils: A Study of Sentence Disparity and Its Reduction, 43 U. CHI. L. REv. 109 (1975); Joseph C. Howard, Racial Discrimination in Sentencing, 59 JUDICATURE 121 (1975); llene H. Nagel \& John Hagan, Gender and Crime: Offense Patterns and Criminal Court Sanctions, 4 CRIME \& JusTICE 91 (1983).

224. For example, Congress identified uniformity in sentencing similar offenders committing similar offenses as a central purpose of the Sentencing Reform Act of 1984:

Sentencing disparities that are not justified by differences among offenses or offenders are unfair both to offenders and to the public. A sentence that is unjustifiably high compared to sentences for similarly situated offenders is clearly unfair to the offender; a sentence that is unjustifiably low is just as plainly unfair to the public.

S. REP. No. 225 , supra note 140 , at $45-46$, reprinted in 1984 U.S.C.C.A.N. at 3228-29.

225. See supra note 8 .

226. See supra notes 6-7 and accompanying text.

227. The state of Washington may have been the first jurisdiction to attempt to structure prosecutorial discretion when its legislature enacted a set of recommended standards for prosecutorial charging and plea bargaining practices as part of its Sentencing Reform Act of 1981. See WASH. REV. CODE ANN. $§ \S 9.94 A .430-.460$ (West 1988 \& Supp. 1992).

Less formal methods are used to channel prosecutorial discretion in other jurisdictions. For example, the Justice Department issued its "Redbook," setting forth Department policy on charging and plea bargaining under the guidelines, on the day the guidelines were to go into effect. See U.S. Dep't of Justice, supra note 164; see also Memorandum from Richard Thornburgh, supra note 164 (modifying the Redbook).

228. Many of the determinate sentencing systems adopted in recent years provide for appellate review. One approach is to permit trial courts to depart from otherwise applicable sentencing ranges only if they state the reasons for departure on the record, with either party allowed to challenge the adequacy of the stated grounds on appeal. See, e.g., WASH. REv. CoDE ANN. § 9.94A.210(2) (West Supp. 1992) (either defendant or the State may appeal a sentence outside the sentence range for the offense).

229. See sources cited supra note 3. 


\section{A. Charge-Based Sentencing Disparity}

Sentencing disparity resulting froin mandatory punishment is very likely to occur in those state courts that apply sentence enhancements im a charge-based format, because individual prosecutors in these courts enjoy broad discretion. ${ }^{230}$ Unlike legislators or sentencing commissioners, deputy prosecutors inust balance the needs of disposing of their caseload and maintaining conviction rates with the competing and sometimes conflicting goal of ensuring consistent punishment withm their jurisdiction. ${ }^{231}$ Plea bargaining thus becomes an appealing tool. Plea agreements ease burdensomc prosecutorial caseloads and eliminate risks associated with trial, such as the exposure of weaknesses in the state's case and the chance of a merciful jury. By offering the dismissal of mandatory sentence enhancements as an inducement for guilty pleas, prosecutors are also able to devote more attention to the preparation and trial of high priority prosecutions.

Available evidence suggests that charge-based inandatory sentence provisions are in fact used primarily as prosecutorial bargaining chips and are only infrequently enforced in actual sentences. A study commissioned by the Arizona Legislative Council exainined the felony sentences imposed in that state during a recent twelve-month period. ${ }^{232}$ The study's authors found that about ten percent of the defendants factually ehigible for the state's three principal mandatory sentence enhancements received those enhanceinents. ${ }^{233}$ Over half the defendants eligible for long mandatory prison sentences under the dangerous offender provision instead received probation. ${ }^{234}$ Twenty-six percent of those eligible for mandatory life sentences under another provision also received probation. ${ }^{235}$ In addition, the study found substantial disparities in the imposition of mandatory punishment. Many of the offenders who received sentences without the mandatory enhancements for which they were eligible had committed offenses as serious as those of the offenders who did

230. See text accompanying notes 71-105 (discussing state prosecutors' broad discretion).

231. On the prosecutor's plea bargaining imcentives, see HeUMANN, supra note 103, at 110-17; Albert W. Alschuler, The Prosecutor's Role in Plea Bargaining, 36 U. CH1. L. Rev. 50, 52-53 (1968). See generally Abraham S. Blumberg, Criminal Justice: Issues \& Ironies 122-44 (2d ed. 1979).

232. Institute for Rational Public Policy, supra note 52, at 8-9 (describing data collection in the study).

233. See id. at 26-31. Of 7472 felony defendants who qualified for a statutory enhancement as "repetitive offenders" because of multiple felony convictions, only 939 (12.5\%) were convicted with the enliancement. See id. at 26-27. Of 2148 felony defendants factually eligible for a statutory enliancement as "dangerous offenders," only 285 (13.2\%) were convicted witl the enhancement. See id. at 27-28. Finally, of 2876 felony defendants wlio had committed their offense while released from confinement for anotlier felony, only $87(3.0 \%)$ were convicted witl tlie applicable sentence enhancement. See id. at 30-31.

234. Id. at 27-28 (these defendants either used a dangerous weapon or inflicted serious injury).

235. Of 640 offenders eligible for mandatory life sentences for committing a dangerons felony wliile released from custody for anotlier felony, $167(26.0 \%)$ were placed on probation. Id. at 30 . 
receive enhanced sentences. ${ }^{236}$

Ad hoc decisionmaking and lack of uniformity inevitably lead to sentence disparities, regardless of who makes the decisions; prosecutors, no less than judges, are susceptible to arbitrariness when exercising unguided discretion. ${ }^{237}$ When deputy prosecutors, sometimes fresh out of law school, determine on a case-by-case basis whether to enforce mandatory enhancement provisions, uneven results are inevitable. ${ }^{238}$ The most troubling aspect of this disparity is that sentences are based partially on whether defendants exercise their constitutional right to trial. Those who are convicted after trial must receive mandatory sentence enhancements while those who plead guilty are eligible for lesser sentences, all at the whim and discretion of prosecutors.

State v. Cocio $^{239}$ vividly illustrates the disparity in sentencing that can result from charge-based mandatory pumishinent when a defendant exercises his right to trial. Cocio's truck collided with a car driven by Rodriguez, killing a passenger in the Rodriguez vehicle. ${ }^{240}$ Both Cocio and Rodriguez were charged with manslaughter and driving under the influence of alcohol. ${ }^{241}$ The prosecution also charged both defendants with mandatory punishment allegations because the two vehicles qualified as "dangerous instruments," 242 and each was on probation at the time of the fatal incident. ${ }^{243}$ Rodriguez entered into a plea agreement with the prosecution and was sentenced to two days in jail, a fine, and a year of probation. ${ }^{244}$ Cocio, however, rejected an identical plea bargain offer and was convicted. Simce he had committed a dangerous felony while on probation, Cocio received a mandatory life sentence with no possibility of parole for twenty-five years. ${ }^{245}$ Ironically, the evidence sug-

236. See id. at 32-33.

237. Commentators predicted the likely disparity that would result from shifting sentencing discretion to prosecutors. See Alschuler, supra note 71 , at $563-76$ (predicting the effects of prosecutors' charge bargaining practices on determmate sentencing systems); Schulhofer \& Nagel, supra note 3, at 238-41 (discussing concern in Congress that prosecutorial plea bargaining discretion could undermine federal sentencing reform).

238. This is demonstrated in State v. Barger, 810 P.2d 191, 197-98 (Ariz. Ct. App. 1990). See supra notes 96-101 and aceompanying text.

239. 709 P.2d 1336 (Ariz. 1985).

240. Id. at 1338 .

241. Id. at 1349-50 \& n.2 (Feldman, J., dissenting).

242. As part of Rodriguez's plea agreement, the state dismissed the "dangerous instrument" addition to his manslaughter charge. Id. at 1350 n.2. In most jurisdictions, a wide variety of instruments qualify as deadly weapons for sentence enhancement purposes. See State v. Meador, 645 P.2d 1257, 1261 (Ariz. Ct. App. 1982) (rock qualifies as a dangerous weapon); Wynn v. Unitcd States, 538 A.2d 1139, 1144 n.14 (D.C. 1988) (pencil); People v. Van, 483 N.E.2d 666, 668 (Ill. App. Ct. 1985) (karate sticks); Cuminings v. State, 384 N.E.2d 605, 606 (Ind. 1979) (stapler).

243. Cocio had successfully completed four years and five inonths of a five-year probationary sentence for an earlier offense. 709 P.2d at 1349 (Feldman, J., dissenting).

244. Id. at 1350 n.2.

245. Id. at 1349,1350 n.2. 
gested that Rodriguez was the more culpable of the two drivers. ${ }^{246}$ Yet Cocio, because of the mandatory sentencing regime, received a punishment vastly harsher than Rodriguez. In effect, Cocio received a life sentence for going to trial. ${ }^{247}$

\section{B. Conduct-Based Sentencing Disparity}

One might expect disparity to be less of a problein in the federal courts because the guidelines' conduct-based sentencing system lessens the importance of prosecutorial discretion. ${ }^{248}$ However, a recent study conducted on behalf of the U.S. Sentencing Commission found substantial unevemiess in the imposition of federal mandatory minimum sentences. Of the 1165 sample cases in which the defendant was factually eligible for a mandatory minimuni sentence, ${ }^{249}$ nearly forty percent of the actual sentences imposed were less than the prescribed statutory minimum. ${ }^{250}$ Thirty-five percent of those defendants possessing or distributing especially large amounts of drugs received sentences without apphicable mandatory minimum penalties, ${ }^{251}$ and approximately fortythree percent trafficking in relatively small amounts of drugs received nonmandatory sentences. ${ }^{252}$ Additionally, defendants involved in ongoing drug trafficking activity were just as likely to be sentenced below mandatory minimums as those for whom only a single incident relating to drugs was known. 253

Most troubling, however, is that $67.7 \%$ of eligible black defendants

246. Id. Justice Feldman, dissenting from the court's rejection of Cocio's Eighth Amendment challenge to the sentence, noted the irony of the case:

It is evident [from the facts shown at trial] that of the two, Rodriguez was the more culpable in terms of both conduct and causation. . . . In my view, the serious disproportionality in the sentences imposed upon Rodriguez and Cocio is not mitigated by the fact that Cocio chose to make the state prove a very close case at trial. Because this defendant chose to exercise his constitutional right to trial, he faces twenty-four years and Id. three hundred and sixty-three days longer in prison than the more culpable actor.

247. The Arizona Supreme Court upheld Cocio's life sentence on appeal. 709 P.2d at 1341-43.

248. See supra text accoinpanying notes 121-47.

249. U.S. SENTENCING CoMm'N, supra note 12, at 55.

250. Id. at 59. Similarly, Gerald W. Heaney, a judge on the United States Court of Appeals for the Eighth Circuit, conducted an empirieal study of guidelines sentencing in the Eighth Circuit, concluding that sentencing disparity was widespread. See Heaney, supra note 3. However, some commentators have questioned Judge Heaney's methodology. See Brown, supra note 117, at 877; Schulhofer, supra note 3, at 837-41; Wilkins, supra note 117, at 799-801.

251. U.S. SENTENCING COMM'N, supra note 12, at 65-66. The study divided cases into three drug ainount categories. The highest category included defendants whose drug amount was at least one kilogram of heroin or an equivalent amount of another drug under guidelines $\S 2 \mathrm{DI} .1$. Id. at 66 n.2.

252. Id. at 66. The "low" drug amount category in the study included defendants whose drug amount was less than 100 grams of heroin or an equivalent amount of another drug under $\S 2 D 1.1$ of the guidelines. Id. at 66 n.2. The "medium" drug amount category included defendants with more than 100 grams of heroin (or equivalent) but less than one kilogram. Id.

253. Id. at 69 . 
received sentences at or above mandatory minimum levels, compared to only $54.0 \%$ of eligible whites. This statistically significant finding held true even when sophisticated multivariate analysis was used to test the data. ${ }^{254}$ These data suggest that in actual practice, mandatory punishinent in the federal courts does not translate into consistent, evenhanded pumishment.

Arguably, prosecutorial discretion justifies soine of this disparity. Defendants who have provided substantial assistance in the investigation or prosecution of others are eligible for departures from the guidelines, on inotion of the prosecution. ${ }^{255}$ The frequency with which mandatory minimums are not applied in the more serious cases most likely reflects the practice of rewarding defendants who provide substantial assistance to the government. Perversely, this disproportionately benefits the defendants most leavily involved in drug trafficking because an offender who is closer to the upper levels of drug distribution organizations is more likely than a lower-level street dealer or a mule to have useful information to sell to the prosecution in plea bargaining.

Prosecutors at times may also wisl to avoid inposition of liarsh mandatory punishments when a punishment would be seriously disproportionate in cases of sympatlietic defendants. Substantial assistance motions and otler plea bargaining practices enable federal prosecutors to evade legislative policy and avoid mandatory punishment in individual cases. In their multiyear study of plea bargaining practices under the gnidelines, Professor Schulhofer and Commissioner Nagel amply demonstrated that prosecutors frequently circumvent harsh penalty structures by means of several devices. ${ }^{256}$ In some cases, prosecutors make substantial assistance motions when defendants in fact liave not provided useful information to the government. ${ }^{257}$ In others, drug trafficking charges are dismissed on grounds that they are "not readily provable."258 Assistant

254. Id. at 76, 82. The data was tested using regression analysis, which is designed to isolate the influence of one variable (here race) while holding other variables constant. Id. at $82 \mathrm{n} .124$. Racerelated disparity in the imposition of federal inandatory punishment increased between 1984 and 1988, and reinained constant thereafter. Id. at 82.

255. GUIDELINES MANUAL, supra note 64 , § 5K1.1.

256. See Nagel \& Schulhofer, supra note 175 (reporting results of an empirical evaluation of plea bargaining practices in three districts); Schulhofer \& Nagel, supra note 3, at 260-84 (reporting pre-Mistretta data on guideline compliance and prosecutorial methods of circumvention). Mandatory minimum sentences were involved in $71 \%$ of the cases in which Nagel and Schulhofer found that federal prosecutors entered into questionable plea bargaining practices to circumvent the Guidelines. llene H. Nagel, U.S. Sentencing Coinınissioner, Address at Judicial Conference of D.C. Circuit (June 12, 1992).

257. See Nagel \& Schulhofer, supra note 175 , at 10.

258. Id. at 8. The "not readily provable" terminology derives from a inemorandum from Attorney General Thornburgh to federal prosecutors dated March 13, 1989, discussing the Justice Department's plea bargaining policy. The Attorney General noted: "Sliould a prosecutor determine in good faith after indictment that, as a result of a change in the evidence or for another reason . . . a cliarge is not readily provable or that an indictment exaggerates the seriousness of an offense or 
U.S. Attorneys also occasionally enter into questionable fact stipulations on such inatters as a defendant's role in the commission of an offense or the amount of drugs involved in an incident for which a defendant has been implicated. ${ }^{259}$ Although Assistant U.S. Attorneys do not enjoy the same level of freedom as their counterparts in state courts with strict charge-based sentencing, the range of federal prosecutorial discretion remains substantial.

Plea bargaining to circumvent mandatory punishment legislation occurs in both state and federal courts neither because prosecutors are a devious lot nor because judges are guilty of malfeasance by accepting plea agreeinents with reduced charges. Instead, circumvention occurs because sentence enhancement statutes cause severe penalties to turn on the existence of a single aggravatimg factor, without regard to other circuinstances that may be present in individual cases. Under 18 U.S.C. $\S 924(c)$, for example, the court inust add a mandatory consecutive sentence of at least five years to the sentence for the underlying offense if the defendant carries or uses a firearm while committing the offense of conviction. A person who has a holstered small caliber handgun in a nearby closet while purchasing a minor amount of drugs in his home receives the same severe statutory enhancennent as a robber who indiscriminately fires a shotgun inside a crowded bank. ${ }^{260}$

Prosecutors who dismiss mandatory enhancement allegations or file questionable substantial assistance motions when plea bargaining with sympathetic defendants are merely trying to assure that just sentences are imposed, and trial judges who tolerate these practices are doing the saine. Iromically, the desire for just results in imdividual cases was a principal cause for disparity in the era of indeterminate sentencing. The frequent atteinpts by prosecutors and judges to evade harsh mandatory

offenses, a plea bargain may reflect the prosecutor's reassessment." Memorandum from Richard Thornburgh, supra note 164 , at 2 .

259. Nagel \& Schulhofer, supra note 175, at 6 (extensive federal fact bargaining concerning amounts and types of drugs, the value of property losses, and defendant's role in the offense); see also Albert W. Alschuler, Departures and Plea Agreements Under the Sentencing Guidelines, 117 F.R.D. $459,473-74$ (1988) (even clear language of guidelines may not prevent all "shading" of the facts in stipulations made by prosecutors and defense attorneys).

260. Courts have consistently upheld convictions under $\S 924(\mathrm{c})$ in cases in which the firearm posed little threat in the commission of the defendant's offense. See, e.g., United States v. Medina, 944 F.2d 60, 66-67 (2d Cir. 1991) (gun on a table in a nearby bedroom), cert. denied, 112 S.Ct 1508 (1992); United States v. Tolliver, 937 F.2d 1183, 1190 (7th Cir.) (revolver carried in a jacket pocket at the time of arrest after an aborted drng transaction), cert. denied, 112 S.Ct 329 (1991); Umited States v. Freisinger, 937 F.2d 383, 387-88 (8th Cir. 1991) (firearms found in a knotted pillowcase inside a large plastic bag in the passenger compartment of a car); United States v. Torres-Medina, 935 F.2d 1047, 1050 (9th Cir. 1991) (defendant a paraplegic physically incapable of retrieving the gun later found in a crawlspace below defendant's house); United States v. Pate, 932 F.2d 736, 73739 (8tl Cir. 1991) (statute violated even tlough defendant did not carry the firearm into the bank, if the gun was available during flight); United States v. Parrish, 925 F.2d 1293, 1297-99 (10th Cir. 1991) (gun on a nearby closet shelf). 
punishment under determinate sentencing result in comparable disparities.

\section{Postconviction Disparity}

Unwarranted disparity resulting from mandatory punishment legislation also occurs in the postconviction stage of criminal cases, at least im those jurisdictions where correctional authorities and parole boards retain the power to release sentenced prisoners from custody. ${ }^{261}$ Persons sentenced pursuant to mandatory enhancement provisions often are ineligible for parole or other forms of release before all or a substantial portion of their prison terms are served. ${ }^{262}$ This, in turn, is a major factor contributing to the mushrooming prison population in every American jurisdiction. ${ }^{263}$ Correctional authorities, faced with overcrowded prisons, are consequently under pressure to consider the early release of persons serving nonmandatory terms to make rooin for persons serving mandatory sentences. This can result in the release of potentially violent offenders im order to provide sufficient space for others who have coinmitted nonviolent crimes. ${ }^{264}$ Thus, disparity occurs indirectly from the imposition of lengthy mandatory sentences.

In sun, disparity is mevitable when harsh inandatory sentencing laws are superimposed on determinate sentencing scheines. Legislatures enact mandatory punishment statutes for utilitarian purposes: to deter violent crime and drug trafficking, and to incapacitate targeted groups of offenders. Proportional punishment is subjugated to these goals. Determinate sentencing reforms will fail in their retributive nission so long as targeted groups of offenders are singled out for severe punishment under rigid sentencing laws.

261. See, e.g., Fla. Stat. ANN. $\$ 947.13$ (West 1985 \& Supp. 1992); MASs. GEN. Laws. ANN. ch. 127, § 128 (West 1991).

262. See, e.g., supra text accompanying notes 93-95.

263. See supra Section I.C.

264. Mandatory sentencing provisions for drug offenses and repetitive criminal activity often require lengthy prison terms for nonviolent offenders. For example, defendants convicted of sale or possession for sale of narcotics and controlled substances in Arizona courts are required to servc lengthy prison terms without parole eligibility, regardless of the amount of drugs involved. See ARIZ. REV. STAT. ANN. \$§ 13-3407(C)-(D), 13-3408(D) (Supp. 1992). The influx of large numbers of such offenders can strain prison systems beyond their capacity. Accommodating them for the duration of their mandatory terms may necessitate early release of those serving nonmandatory terms, even though those so released may have committed serious offenses. The Director of the Arizona Department of Corrections, noting that 1000 inmates would be without beds by the middle of 1992, acknowledged a year earlier that the Department of Corrections would be forccd to release violent offenders early to make room for nonviolent drug offenders serving mandatory minimum sentences. Hentoff \& Johns, supra note 86 , at $\mathrm{Cl}$. 


\section{IV}

\section{Constitutional Challenges to Mandatory Sentencing}

Postconviction challenges to mandatory sentences have raised constitutional arguments relating to both the severity of punishment and the rigidity of sentencing schemes that do not permit courts to consider mitigating circumstances. ${ }^{265}$ Most of these challenges have been unsuccessful. The Supreine Court has rarely been willing to question legislative policy concerning criminal sanctions. Lower courts also generally defer to the legislative branch.

\section{A. Challenges to the Severity of Punishment Enhancements}

Many defendants, relying on the Eighth Amendment, have contended that their severe prison sentences were grossly disproportionate to the harms caused by their crimes. ${ }^{266}$ The Eighth Amendment includes

265. In addition to the severity and rigidity issues, defendants have challenged the arbitrariness of the criteria used to trigger harsh mandatory punishment, basing arguinents on equal protection grounds. Many federal defendants, for example, have questioned the sentencing scheine of 21 U.S.C. $\$ 841$ (b), which classifies violators on the basis of the weight of mixtures or substances containing detectable amounts of drugs, without regard to the purity of those mixtures or substances. 21 U.S.C. \$ 841(b) (1988 \& Supp III 1991). However, this provision has been upheld consistently. See, e.g., United States v. Holines, 838 F.2d 1175, 1177-78 (11th Cir.) (sentencing scheme rationally related to Congress' objective of protecting public health and safety), cert. denied, 486 U.S. 1058 (1988); United States v. Restrepo, 676 F. Supp. 368, 377 (D. Mass. 1987) (classification scheme not arbitrary or irrational), aff'd, 867 F.2d 605 (1st Cir. 1988). The Supreme Court settled the issue im Chapman v. United States, 111 S. Ct. 1919 (1991), holding that Congress had a rational basis for its classification scheme with regard to LSD because the statute accomplishes the severe punishment of all large-scale drug dealers, at both the wholesale and street levels. Id. at 1927-28. State courts have also generally denied equal protection clains related to the arbitrariness of mandatory punishment classifications. See Middleton v. State, 506 A.2d 1191, 1195-97 (Md. Ct. Spec. App. 1986) (chargebased recidivist statute not violative of equal protection despite the broad sentencing discretion given to prosecutors and the resulting sentence disparities), cert. denied, 517 A.2d 771 (Md. 1986); Coinmonwealth v. Jones, 543 A.2d 548, 550-52 (Pa. Super. Ct. 1988) (state's inandatory punishment scheine for crimes committed near public transportation deemed rationally related to the Legislature's interest in protecting and promoting use of public transportation), appeal denied, 559 A.2d 35 (Pa. 1989); State v. Copeland, 765 P.2d 1266, 1268-70 (Utah 1988) (statute not arbitrary im allowing probation only for parents and legal guardians in child rape cases).

266. See Young v. Miller, 883 F.2d 1276, 1285-86 (6th Cir. 1989) (upholding a mandatory sentence of life imprisonment without parole imposed by a Michigan court on a first-tine offender convicted of possession with intent to distribute heroin), cert. denied, $111 \mathrm{~S}$. Ct. 2886 (1991); United States v. Kidder, 869 F.2d 1328, 1333-34 (9th Cir. 1989) (upholding the imposition of a five-year mandatory minimum sentence for a defendant convicted of possession with intent to distribute cocaine); Terrebonne v. Butler, 848 F.2d 500, 507 (5th Cir. 1988) (upholding a mandatory life sentence without parole imposed on a heroin addict with two prior convictions for distributing heroin, both probably coininitted to support habit), cert. denied, 489 U.S. 1020 (1989); State v. Foley, 456 So. 2d 979, 981-82 (La. 1984) (affirming a mandatory sentence of life imprisonment without possibility of parole for a juvenile defendant convicted of aggravated rape); Horsinan v. State, 570 A.2d 354, 358 (Md. Ct. Spec. App. 1990) (affirming a mandatory 25-year sentence without possibility of parole for defendant with two prior convictions convicted of attempted daytime house breaking with intent to steal), cert. denied, 582 A.2d 531 (Md. 1990); State v. Higginbottoin, 324 S.E.2d 834, 837 (N.C. 1985) (upholding a mandatory life sentence for a defendant convicted of sexual assault involving a four-year-old girl); State v. Russell, 791 P.2d 188, 190 (Utah 1990) 
an explicit proportionality requirement in its prohibition of excessive fines. ${ }^{267}$ Additionally, the Supreine Court has interpreted the Cruel and Unusual Punishments Clause of the same Amendment to preclude the imposition of the death penalty when the punishment exceeds the gravity of the defendant's offense. ${ }^{268}$ Since neitlier the lesser pumshment of a criminal fine nor the greater pumshment of death may be imposed when disproportionate to a defendant's offense, one might expect that the Eighth Amendment may also be interpreted to include a proportionality requirement witl regard to imcarceration. The Supreme Court, however, has repeatedly vacillated on this issue.

In Weems v. United States, ${ }^{269}$ a 1910 case, a defendant in the Philippimes was convicted of the relatively minor offense of falsifying a public docunient. ${ }^{270} \mathrm{He}$ was sentenced to fifteen years of cadena temporal, which consisted of imprisonment, hard labor in chains fastened to the wrists and ankles, and lifetime loss of civil liberties. ${ }^{271}$ The Supreme Court overturned the sentence as violative of the Cruel and Unusual Punishments Clause. ${ }^{272}$ The Court reversed in part because of the unique nature of the punishment, but also because "it is a precept of justice that punishment for crime should be graduated and proportioned to offense." 273

Despite this expansive precedential language, a five-member nıajority of the Court refused to second-guess a legislative deterimination of proportionality in the 1980 case of Rummel v. Estelle, ${ }^{274}$ in which the Court upheld a life sentence under a Texas recidivist statute for a defendant who had been convicted of three nonviolent felonies involving relatively minor thefts of property. ${ }^{275}$ The Court again declined to engage in a proportionality review of a noncapital sentence in Hutto v. Davis, ${ }^{276}$ a 1982 per curiam opinion that upheld a forty-year sentence for the posses-

(upholding a mandatory minimum sentence for a juvenile prosecuted as an adult and convicted of aggravated sexual assault, robbery, and kidnapping).

267. The Eighth Amendment provides that "[e]xcessive bail shall not be required, nor excessive fines imposed, nor cruel and unusual pumishments inflicted." U.S. CoNST. amend. VIII.

268. See Enmund v. Florida, 458 U.S. 782 (1982) (death penalty for felony-murder violates the Eighth Amendment when defendant did not take life, attempt to take life, or intend that life be taken, or when lethal force was not used); Coker v. Georgia, 433 U.S. 584 (1977) (plurality opinion) (sentence of death violates the Eighth Amendment because it is disproportionate to the crime of rape of an adult woman).

269. 217 U.S. 349 (1910).

270. Id. at 357-58.

271. Id. at $358,364-65$.

272. Id. at 352 .

273. Id. at 367.

274. 445 U.S. 263 (1980).

275. Id. at 285. The defendant in Rummel was convicted of obtaining $\$ 120.75$ by false pretenses and had two prior nonviolent felony convictions, one involving fraudulent use of a credit card for $\$ 80.00$ and the other involving passing a forged check for $\$ 28.36$. Id. at 265-66.

276. 454 U.S. 370 (1982) (per curiam). 
sion of less than nine ounces of marijuana. ${ }^{277}$ Nevertheless, a five-member majority in Solem v. Helm ${ }^{278}$ declared a year later that the imposition of a life sentence without parole for a defendant convicted of seven nonviolent felonies violated the Eighth Amendment. ${ }^{279}$

The Court moved away from the principles of Solem in Harmelin $v$. Michigan, ${ }^{280}$ its latest pronouncement on proportionality. Harmelin was convicted of possessing 672 grams of cocame. ${ }^{281}$ The trial court sentenced him to life imprisonment without possibility of parole pursuant to a Michigan statute requiring such punishment whenever a person is convicted of possessing more than 650 grams of a mixture containing cocaine. ${ }^{282}$ Under the Michigan statute, the purity of the mixture and whether the person intends to distribute the drug are irrelevant to the court's sentencing decision. ${ }^{283}$

The Supreme Court sphit three ways on Harmelin's claim that his life sentence constituted cruel and unusual punishment, with no opinion for the Court on the issue. ${ }^{284}$ Justice Scalia, writing for himself and Chief Justice Rehnquist, concluded that Solem should be overruled and that the permissible length of prison sentences should be purely a matter for legislative determination. ${ }^{285}$ The other seven Justices found a proportionality requirement apphicable to incarceration in the Cruel and Unusual Puinshments Clause but disagreed over the extent to which courts should defer to legislative determinations concerning the gravity

277. Id. at 371-72.

278. 463 U.S. 277 (1983).

279. Id. at 279,303 . The majority distinguished Rummel on the grounds that the defendant in that case had the possibility of winning parole, whereas the defendant in Solem was given a sentence with no eligibility for release absent executive cleınency. Id. at 300-03.

280. 111 S. Ct. 2680 (1991).

281. Id. at 2684 (plurality opinion).

282. Id. at 2684 \& n.1.

283. Id. at $\mathbf{2 7 1 6}$ (White, J., dissenting).

284. The Harmelin Court affirmed the Michigan Court of Appeals' decision upholding the sentence. $111 \mathrm{~s}$. Ct. at 2702 . Two menibers of the Court voted to affirm because they found no Eighth Amendnient proportionality requirement applicable to noncapital sentences. Id. at 2684-702 (Scalia, J., \& Rehnquist, C.J.). Three other melnbers voted to affirm on the ground that, given the severity of the crime of cocaine distribution, the sentence was constitutional under the narrow proportionality test that they concluded was applicable to noncapital sentences. Id. at 2702-09 (Kennedy, O'Connor, \& Souter, JJ., concurring in part and in the judguient). The four dissenters believed the sentence was unconstitutionally disproportionate to the offense. Id. at 2709-20 (White, Blackmun, \& Stevens, JJ., dissenting); id. at 2720 (Marshall, J., dissenting).

285. Justice Scalia would have overruled Solenı v. Helm, 463 U.S. 277 (1983), contending that it was wrongly decided. Harmelin, $111 \mathrm{~S}$. Ct at 2686 (plurality opinion). His opinion offered a detailed historical analysis leading to the conclusion that the term "cruel and unusual punishments" was not understood at the time of the adoption of the Eighth Amendnuent to include the concept of proportionality. Id. at 2686-96. Justice Scalia then opined that appellate review of sentencing that includes a proportionality analysis merely substitutes judges' subjective views of the gravity of offenses for legislative determinations. Id. at 2697-98. 
of offenses. ${ }^{286}$

Justice Kennedy, joined by Justices O'Connor and Souter, concurred in the affirmance of Harmelin's sentence. Justice Kennedy atteinpted to reconcile the Court's seemingly inconsistent earlier decisions by concluding that each case recognized a "narrow" proportionality requirement in the Cruel and Unusual Punishments Clause. ${ }^{287}$ Justice Kennedy cautioned that the fixing of prison terms is "properly within the province of legislatures, not courts," "288 and einphasized that the Eighth Amendinent "forbids only extreme sentences that are "grossly disproportionate' to the crime."289 Unlike the four dissenters, Justice Kennedy saw no need to coinpare Harmelin's sentence with those imposed for other offenses in the State of Michigan or with those imposed for possession of a similar ainount of cocaine in other jurisdictions. ${ }^{290}$ In his view, no punishment of incarceration, even life imprisonment without parole, wonld be grossly disproportionate to an offense involving the possession of a substantial amount of drugs. ${ }^{291}$ Drug possession, reasoned Justice Kennedy, always poses a substantial threat of violence because drug users are likely to commit other offenses and because violence is part of the drug business. ${ }^{292}$ Thus, according to this view, even if an offender's own actions do not threaten the safety of others, he may nevertheless be incarcerated for the remainder of his hife because others committing the saine offense are clangerous. ${ }^{293}$

In his dissenting opinion, Justice White agreed that courts should give "substantial deference" to legislative punishment graclations, ${ }^{294}$ but would have apphed the three-prong test articulated in Solem to determine whether a particular sentence of incarceration constituted cruel and unusual punishinent. ${ }^{295}$ Under this test, a proportionality review should

286. Id. at 2702 (Kennedy, J., concurring in part and in the judgment); id. at 2709 (White, J., dissenting); id. at 2719 (Marshall, J., dissenting).

287. Id. at 2702 (Kennedy, J., concurring in part and in the judgment).

288. Id. at 2703 (quoting Ruinmel v. Estelle, 445 U.S. 263, 275-76 (1980)).

289. Id. at 2705 (quoting Solem v. Helm, 463 U.S. 277, 288 (1983)).

290. Justice White's dissenting opinion argued that stare decisis required the application of the thrce-prong test announced in Solem v. Helın, 463 U.S. 277, 292 (1983). See infra note 298 and accoinpanying text.

291. Harmelin, $111 \mathrm{~S}$. Ct. at 2706-07 (Kennedy, J., concurring in part and in the judgment).

292. Id. at 2706. Justice Kennedy also coinmented:

Quite apart from the pernicious effects on the individual wlio consumes illegal drugs, such drugs relate to crime in at least three ways: (1) A drug user may cominit crime because of drug-induced changes in physiological functions, cognitive ability, and mood; (2) [a] drug user may commit crime in order to obtain money to buy drugs; and (3) [a] Id. violent crime may occur as part of the drug business or culture.

293. Justice Kennedy contrasted Harmelin's crime with that of the defendant in Solem, whose offenses " "involved neither violence nor the threat of violence to any person.' " Id. at 2705 (quoting Solem, 463 U.S. at 296).

294. Id. at 2713 (White, J., dissenting).

295. Id. at 2716-19. Justices Blackmun and Stevens joined Justice White's opinion and Justice 
be guided by "objective criteria," which include: (1) the gravity of the defendant's offense and the harshness of the penalty; (2) the sentences imposed on other criminals in the same jurisdiction; (3) the sentences imposed for the same offense in other jurisdictions. ${ }^{296}$ In weighing the gravity of an offense, the Harmelin dissenters attached importance to the "degree of violence" involved in a crime, just as Justice Kennedy did. ${ }^{297}$ However, they disagreed with Justice Kennedy on the appropriateness in drug possession cases of looking beyond the scope of the defendant's own conduct to generalized notions of drug users and traffickers. ${ }^{298}$

Although the Court disagreed on the existence and scope of an Eighth Amendinent proportionality requirement in noncapital cases, certain poimts emerge clearly from Harmelin. First, no member of the Court would interfere with a legislative grading of noncapital punishment for potentially violent crime. Both the concurring and dissentimg opinions indicate judicial disinchination to review even those laws that mandate life imprisonment without any eligibility for release for offenses that directly threaten the physical safety of others. Hence, a legislature can be as harsh as it desires without crossing constitutional hines in mandating incarceration for such inatters as possession of weapons in the commission of offenses or conduct that impairs the safety or well-being of vulnerable victims such as children or elderly persons. ${ }^{299}$

Second, a majority of the Court would let stand any period of incarceration, including life imprisonment without parole, for all drug trafficking or siniple possession convictions where the defendant possesses a substantial amount of the drug in question. ${ }^{300}$ Regardless of the risk of violence in the defendant's own conduct, the three concurring Justices categorized the possession of drugs as inherently dangerous because of

Marshall indicated in a separate opinion that he agreed with Justice White's arguments concerning proportionality. Id. at 2719 (Marshall, J., dissenting).

296. Solem, 463 U.S. at 292.

297. Justice White commented: "[ $[\mathrm{n} n$ evaluating the gravity of the offense, it is appropriate to consider 'the harm caused or threatened to the victim or society,' based on such things as the degree of violence involved in the crime and ' $\mathrm{t}]$ he absolute magnitude of the crime,' and 'the culpability of the offender[ [' ...." Harmelin, $111 \mathrm{~S}$. Ct at 2716 (White, J., dissenting) (quoting Solem, 463 U.S. at 293).

298. Id. at 2716-17. Applying this standard to Harmelin's case, Justice White found the sentence of life inprisonment without parole to be grossly disproportionate because there was no evidence that Harmelin, a first-time offender, had personally threatened anyone. Id, at 2716. Justice White found the "'absolute inagnitude" " of Harmelin's offense to be "not exceptionally serious" because he was not alleged to have had the intent to distribute the drug and because the statute did not require any particular degree of purity in the mixture he possessed. Id. at 2717. The dissenters concluded that the Michigan statute requiring life inprisoninent without parole for drng possession violates the Eighth Amendment since Michigan punishes many offenses involving actual violence less severely and no other jurisdiction imposes nearly as harsh a penalty for simple possession. Id. at 2718.

299. See supra note 37 (discussing statutory penalties for crimes cominitted with firearms).

300. Justice Marshall was one of the dissenters in Harmelin. With his replacement by Justice Thomas, it is even less likely that the Court will disturb a harsh noncapital sentence in a drng case. 
the violence generally associated with drug traffic. ${ }^{301}$ This reasoning unrealistically ignores the frequent situations in which persons marginally connected with drug trafficking serve as couriers for those who wish to avoid detection. ${ }^{302}$ While felony punishment for the peripheral drug trafficking participant is appropriate, life imprisoninent without possibility of parole is grossly disproportionate. Whell viewed with Hutto, ${ }^{303}$ however, Harmelin signals complete judicial deference to the legislative branch's determination of penalties for drug offenses. ${ }^{304}$

\section{B. Challenges to the Rigidity of Sentence Enhancements}

Convicted defendants have also had hittle success im challenging statutes that drastically limit or remove trial court discretion to consider mitigating circunistances and to impose sentences below mandatory minimuni statutory levels when mitigating circumstances are present. Some challenges have argned that individualized sentencing is a hiberty interest protected by due process, but no court has been willing to recognize such a substantive right. ${ }^{305}$ For example, the Third Circuit concluded that individualized treatment in sentencing, unlike substantive liberty interests in freedom from civil commitment or freedom from excessive pliysical force, is not "a right inherent in the human condition." 306 Other defendants have contended that depriving judges of sentencing discretion

301. See supra note 292. Presumably, this approach would apply even to possession of smaller amounts of drugs that are frequently associated with a high degree of violence, such as crack cocaine.

302. The case of the teenage filing clerk described by Judge Harry Hupp, see infra note 316, is an excellent example of relatively uninor offense behavior that might trigger a permissible sentence of life inprisonment without parole under Justice Kennedy's approach.

303. 454 U.S. 370 (1982) (per curiam) (upholding a 40-year sentence for possession of a relatively sinall amount of marijuana).

304. It seems safe to conclude that life imprisonment inay be constitutional for all nonviolent felonies, so long as the offender remains eligible for parole or sinilar release. E.g., Rummel v. Estelle, 445 U.S. 263 (1980) (npholding a life sentence for a nonviolent recidivist). The combination of Rummel and Harmelin assures that the Eighth Amendinent is potentially implicated in noncapital felony cases only when small-scale property offenders, and possibly persons possessing small amounts of drugs like marijuana for their own use, are sentenced to life imprisoninent without parole eligibility.

305. See, eg., Ehrsam v. Rubenstein, 917 F.2d 764, 766 (3d Cir. 1990) (no due process right to individualized sentencing), cert. denied, 111 S. Ct. 1324 (1991); United States v. Wilkins, 911 F.2d 337, 339 (9th Cir. 1990) (Congress not required to grant courts discretion to individualize sentences); United States v. White, 869 F.2d 822, 825 (5th Cir.) (per curiam) (no constitutional requirement of individualized sentences), cert. denied, 490 U.S. 1112 (1989); United States v. Goodface, 835 F.2d 1233, 1236 (8th Cir. 1987) (niandatory sentence does not violate due process despite limiting the sentencing judge's discretion); United States v. Oxford, 735 F.2d 276, 278 (7th Cir. 1984) (due process does not include the right to rehabilitation). But see United States v. Barkcr, 771 F.2d 1362, 1365-69 (9th Cir. 1985) (when the sentencing court does have discretion to consider mitigating circumstances, it inust do so).

306. United States v. Frank, 864 F.2d 992, 1009 (3d Cir. 1988), cert. denied, 490 U.S. 1095 (1989). Courts have also reasoned that recognizing a substantive liberty interest in individualized sentencing would be inconsistent with legitimate purposes of punishnent, such as general deterrence and retribution, served by inandatory penalties. Id. at 1009-10. 
violates the separation of powers doctrine by impairing the judicial branch in one of its traditional functions. This argument has also failed under both federal and state constitutions because sentencing has historically been a responsibility shared by the three branches of government. ${ }^{307}$ Courts frequently note that legislatures have the constitutional authority to curtail judicial discretion completely with fixed sentences, at least in noncapital cases. ${ }^{308}$

The strongest arguinents for individualized sentencing have been based on the Eighth Amendment's prohibition of cruel and unusual punishments. A central coinponent of the Supreine Court's Eighth Amendnient jurisprudence in capital cases is the defendant's right to an individualized determination of the appropriateness of the death penalty. ${ }^{309}$ The sentencer in a capital case nuust "not be precluded froin considering, as a mitigating factor, any aspect of a defendant's character or record and any of the circuinstances of the offense that the defendant proffers as a basis for a sentence less than death." ${ }^{110}$ Thus, for example, a statute requiring the punishment of death for nuurder committed by a person serving a life sentence violates the Eighth Amendinent. ${ }^{311}$ Underlying these cases is the notion that a "fundaniental respect for humanity" hies at the core of the Eighth Amendment, ${ }^{312}$ and that humane pumishinent is undermined and coinpromised by a sentencing process that "treats all persons convicted of a designated offense not as uniquely individual human benigs, but as nieinbers of a faceless, undifferentiated nıass." $" 313$

Harmelin presented a coinpelling opportunity for the Court to extend this doctrine to at least soine noncapital cases. Harmelin's sentence of life imprisoninent without parole was the ultimate punishment

307. See United States v. Huerta, 878 F.2d 89, 93 (2d Cir. 1989) (sentencing not solely or inherently a judicial function, and the legislative branch can limit or remove judicial discretion in sentencing), cert. denied, 493 U.S. 1046 (1990); Frank, 864 F.2d 992, 1010 (3d Cir. 1988) (although pronouncing sentence after a trial or guilty plea is inherently a judicial function, determining sentence is not); People v. Meeks, 285 N.W. 2d 318, 322 (Mich. Ct. App. 1979) (legislatures free to retain or delegate sentencing discretion when definimg offenses and prescribing punishment); State v. Todd, 570 A.2d 20, 28 (N.J. Super. Ct. App. Div. 1990) (" '[S]entencing power' has never been the exclusive province of the judiciary in all aspects.").

308. See Mistretta v. United States, 488 U.S. 361, 36465 (1989) (scope of judicial discretion with respect to federal crimes is a matter of congressional control); United States v. Grayson, 438 U.S. 41,45 (1978) (discussing legislatively fixed sentences during the early days of the Republic).

309. See Eddings v. Oklahoma, 455 U.S. 104, 113-14 (1982); Lockett v. Ohio, 438 U.S. 586, 604 (1978); Woodson v. North Carolina, 428 U.S. 280, 302-03 (1976) (plurality opinion).

310. Lockett, 438 U.S. at 604.

311. Sumner v. Shuman, 483 U.S. 66, 85 (1987).

312. Woodson, 428 U.S. at 304 (plurality opinion). Justices Stewart, Powell, and Stevens explained: "[W]e behieve that in capital cases the fundamental respeet for humanity underlying the Eighth Amendinent requires consideration of the character and record of the individual offender and the circumstances of the particular offense as a constitutionally indispensable part of the process of inflicting the penalty of death." Id. (citation omitted).

313. Id. 
in Michigan, a state that does not have a death penalty. ${ }^{314}$ One could argue persuasively that a statute requiring a first offender to be incarcerated for the reinainder of her life, regardless of the circuinstances of the case, treats all convicted offenders as "members of a faceless, undifferentiated mass." 315 This is especially true when the crime in question relates to the possession of drugs without any requirement of an intent to distribute. Although many persons apprehended with more than 650 grams of cocaine in their possession undoubtedly are large-scale traffickers, the opposite is soinetimes true, when otherwise law-abiding persons agree to hold or transport drugs for relatives or acquaintances. ${ }^{316}$ The blanket issuance of life sentences without regard for mdividual circumstances strips the sentencing process of an essential proportionatity mechanisin.

Harmelin, however, refused to extend the right of individualized sentencing to noncapital cases. Justice Scalia's opimion for the Court first noted that "[s]evere, mandatory penalties may be cruel, but they are not unusual in the constitutional sense, having been employed in various forms throughout our Nation's history." 317 Conceding that Harmelin's penalty was the "second most severe" punishment known to the law, Justice Scalia emphasized that it still could not compare with the irrevocability of the death penalty because with life inprisonment "there remain the possibilities of retroactive legislative reduction and executive clemency." ${ }^{318}$ The Court also rehed on precedent in affirming Harmelin's inandatory sentence, noting that the death penalty cases recognizing a right to individualized sentencing "repeatedly suggested" that there was no comparable requirement in noncapital cases. ${ }^{319}$

Even if the Court had recognized a constitutional requirement of individualized sentencing in the circumstances of Harmelin's case, its

314. Harmelin v. Micligan, 111 S. Ct. 2680, 2716 (1991) (White, J., dissenting).

315. Woodson, 428 U.S. at 304 (plurality opinion).

316. An increasing number of judges are publicly criticizing mandatory sentencing laws that require them to sentence situational drug offenders to long prison terms. See, e.g., Katherine Bishop, Mandatory Sentences in Drug Cases: Is the Law Defeating Its Purpose?, N.Y. TimEs, Junc 8, 1990, at B16 (noting increasing criticism of drug laws by federal judges); Paul W. Valentine, Margarine Heiress Gets 14 Years for Cocaine Distribution in Maryland, WASH. Post, Mar. 9, 1990, at A18 (same). U.S. District Court Judge Harry Hupp in Los Angeles recently described a case in which he was required to impose a long prison sentence for a teenage filing clerk convicted of possession of crack cocaine. The clerk, Margaret Mitcliell, whose only prior contact with the law was a speeding ticket, was cauglit with 504 grams of the drug iu a gym bag. Mitchell had agreed to transport the drug for her brother in excliange for \$250, which slie planned to use to buy Christmas presents. Judge Hupp lamented: "Here's a young person at the beginning of her life, and suddenly the world has closed in on lier. This is not the type of case to lock "em up and throw the key away." Aaron Epstein, Judges Protesting Mandatory Drug Sentences, SeatTle TiMES, May 19, 1991, at A7.

317. Harmelin, $111 \mathrm{~S}$. $\mathrm{Ct}$ at 2701.

318. Id. at 2702.

319. Id. Even the four Harmelin dissenters did not argue for an extension of the death penalty rule to cases involving mandatory life inprisonment, probably because of the repeated references in the earlier cases to the uniqueness of the death penalty. See id. at 2709-19 (White, J., dissenting); $i d$. at 2719 (Marslrall, J., dissenting). 
ruling would have had hittle practical significance for most defendants sentenced under mandatory punishment statutes because the large majority of these provisions do give courts discretion to consider mitigating circunistances. Although penalty enhancement laws normally prohibit probation and suspended sentences and require that sentences ineet or exceed mandatory minimun levels, ${ }^{320}$ maximum sentences are also usually enhanced. Thus, under the typical format of a mandatory punishment statute, the court continues to have discretion to impose a sentence withm a range of alternatives, but the entire range is increased. ${ }^{321}$ These statutes are "Inandatory" not because they totally eliminate judicial discretion and require a specifically fixed sentence, but simply because they require severity.

\section{CONCLUSION}

Since Harmelin inakes clear that courts are not going to amehorate the untoward effects of mandatory sentencing laws, the legislative branch must recognize that mandatory punishment is bad policy. ${ }^{322}$ Statutes requiring harsli sentence enhanceinents for specified conduct represent an effort by legislatures to micromanage sentencing by insisting that offenders who commit serious offenses always get severe punishment. Although these provisions undoubtedly increase both the percentage of persons sentenced to prison and the duration of their confinement, there is no guarantee that they in fact separate out the worst offenders. Many individuals who are not sentenced pursuant to mandatory pumishment provisions liave committed more serious offenses than others who have received enhanced punishment. There is evidence of discriminatory enforcement of inandatory punishment laws against blacks, and the defendants who are punished most severely tend to be those who exercise their constitutional riglits. Mandatory punishment laws also give prosecutors enormous power to force defendants to enter guilty pleas, and in certain circunistances threaten the constitutional riglit to be free froin unreasonable searches and seizures.

Most of these difficulties stem from the combination of rigidity and severity in mandatory punishment laws. Isolating a single aggravating

320. See supra notes $24-27$ and accompanying text.

321. This is illustrated by the federal statutory scheme for the possession of cocaine with intent to distribute. The basic penalty for this offense, absent any punishment enhancements, is a term of incarceration not to exceed 20 years. 21 U.S.C. $\$ 841(b)(1)(C)$ (1988). If the offender possesses 500 grams or more of a mixture or substance containing the drug, the minimum sentence increases to 5 years in prison; the maximum sentence is also increased, to 40 years. Id. $\S 841(\mathrm{~b})(1)(B)$ (1988 \& Supp. III 1991). Similarly, if the weight of the mixture is five kilograms or more, the ininimum sentence is 10 years and the maximum is life imprisonment. Id. $\S 841(\mathrm{~b})(1)(\mathrm{A})$.

322. A number of critics of the federal mandatory minimum sentence statutes have argued that the mandatory minimums should be repealed. See U.S. SENTENCING COMM'N, supra note 12, at 2034; Gerald Heaney, Revisiting Disparity: Debating Guidelines Sentencing, 29 AM. CRIM. L. REV. 771, 786 (1992); Schulhofer, supra note 3, at 848. 
circumstance for a harsh mandatory sentence enhancement without regard for the total mix of facts in individual cases can lead to grossly unfair penalties for minor offenders and a consequential misuse of valuable correctional resources. These probleins occur regardless of whether a jurisdiction bases sentencing on the charges of conviction or, alternatively, on the defendant's actual conduct. In charge-based sentencing systems, prosecutors routimely charge mandatory punishment allegations for plea bargaining leverage. If a defendant instead chooses to go to trial and is found guilty, the court must mipose the severe sentence regardless of the strength of mitigating circumstances in the case. The combination of rigidity and severity results in even worse problems in conduct-based sentencing because the court frequently must impose the harsh mandatory sentence regardless of the prosecutor's charging decision. This in turn leads to manipulation of charges and spurious substantial assistance motions to circuinvent penalties that the parties and the court find inappropriate. Regardless of whether a jurisdiction uses chargebased sentencing or conduct-based sentencing, mandatory punishment laws result in unwarranted disparity. Consequently, they should be repealed, at least in their current form.

Legislatures can deal sensibly with the rigidity issue even without addressing the severity issue by providing that the sentences prescribed by such laws are presumptive in nature, rather than required. ${ }^{323}$ This would permit a trial court to depart from a disproportionately severe sentence requirement in appropriate cases and instead choose a penalty froin the applicable sentencing range for the defendant's offense without the enhancement factors. ${ }^{324}$ To prevent unwarranted use of this authority, legislatures should follow the lead of several states by authorizing downward sentence departures only when a court finds "substantial and coinpelling" mitigating circuinstances and states its findings on the record, with a prosecutorial right to appeal. ${ }^{325}$ This could lead to the developinent of a common law of sentencing, informing trial courts when departures froin presumptive sentence enhanceinents are appropriate.

In contrast, Congress permits departures froin the guidelines only if

323. See Mich. Comp. LAws ANN. § 333.7401(3) (West 1982 \& Supp. 1991) (permitting trial judges to depart from otherwise mandatory minimum sentences if the court finds "substantial and compelling reasons" for the departure). The Michigan Legislature enacted this amendment to its mandatory sentence statute in 1988. See People v. Downey, 454 N.W.2d 235, 238 (Mich. Ct. App.) (legislative intent was to give judges discretion to sentence below the mandatory minimum), appeal denied, 436 Mich. 871 (1990); see also PARENT, supra note 3, at 183-85 (Minnesota accomplished the same result both by legislation and by court decision).

324. Judges who do not have this flexibility frequently complain about the unfairness of the sentences they sometimes must impose. See, e.g., supra note 101 (quoting State v. Barger, 810 P.2d 191, 197-98 (Ariz. Ct. App. 1990)).

325. See, e.g., WASH. REv. CODE ANN. \$ 9.94A.390(1) (West 1988) (permitting departures for "substantial and compelling" reasons, stated on the record; each party given right to appeal); MiNN. SENTENCING GUIDELINES § II.D.2(a) (same); OR. ADMIN. R. 253-08-001 (1991) (same). 
the court finds "an aggravating or mitigating circumstance of a kind, or to a degree, not adequately taken into consideration by the Sentencing Commission in formulating the guidelines."326 The more flexible state approach, using the "substantial and coinpelling" standard, is superior because it focuses entirely on circumstances of the individual case. The federal guidelines preempt and preclude individual judicial determinations with Sentencing Commission consideration of circumstances in the aggregate. ${ }^{327}$ In those cases in which an aggravating circuinstance (for example, possession of a weapon or large amount of drugs) is balanced by facts that would otherwise call for a mitigated sentence, apphication of the "substantial and compelling" departure standard should result in sentences that are inore proportionate to the defendant's offense.

The severity of mandatory punishment presents a more difficult political issue. What legislator wants to appear soft on crime by decreasing penalties for offenses involving violence or drugs? However, bringing harsli statutory puirishment enhancenients in line with other penalty gradations would increase the likelihood that punishment is actually enhanced for such factors as prior criminal record, the use or possession of a weapon during the commission of an offense, the antount of drugs in a transaction, or the special vulnerability of a crime victim. A niajor problem of extremely harsh sentence enhancenients is that often they are not enforced; the inore severe the enhancenient, the inore likely that courtroonı players will ignore or circumvent it. Moreover, when the weight given in sentencing to enhancement factors is reasonably proportional to the weight of all other circunistances taken into account in guideline or presuinptive sentencing scheines, legislative pohicy is niore likely to be umformly followed. Thus, by reducing the severity of mandatory punishment provisions, a legislature would take a inajor step toward achieving consistency and proportionality in sentencing.

326. 18 U.S.C. $\$ 3553(b)$ (1988).

327. On the rigidity of the federal departure standard, see Judy Clarke \& Gerald McFadden, Departures from the Guideline Range: Have We Missed the Boat, or Has the Ship Sunk?, 29 AM. CRIM. L. REV. 919 (1992) (arguing that federal courts have misconstrued the Sentencing Reform Act of 1984 by interpreting the departure standard narrowly); Freed, supra note 3, at 1744-47 (arguing that the Federal Sentencing Commission sent mixed messages concerning trial court departure power, and courts have interpreted that power narrowly); Schulhofer, supra note 3, at 861-70 (arguing that the federal departure rule is too narrow and inflexible). 
